Prepared in cooperation with the North Platte Natural Resources District

Determination of Canal Leakage Potential Using Continuous Resistivity Profiling Techniques, Interstate and Tri-State Canals, Western Nebraska and Eastern Wyoming, 2004
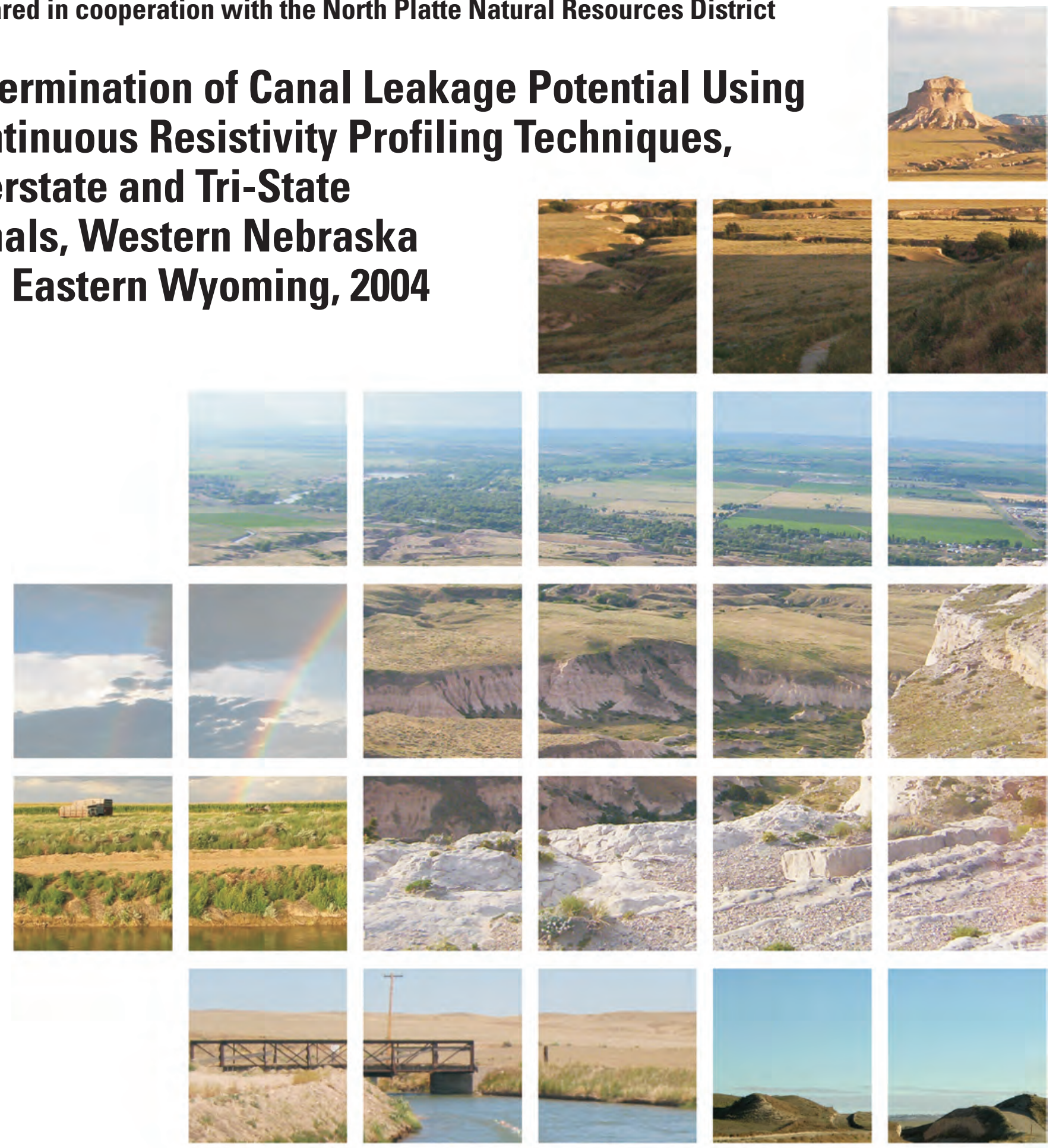

Scientific Investigations Report 2006-5032
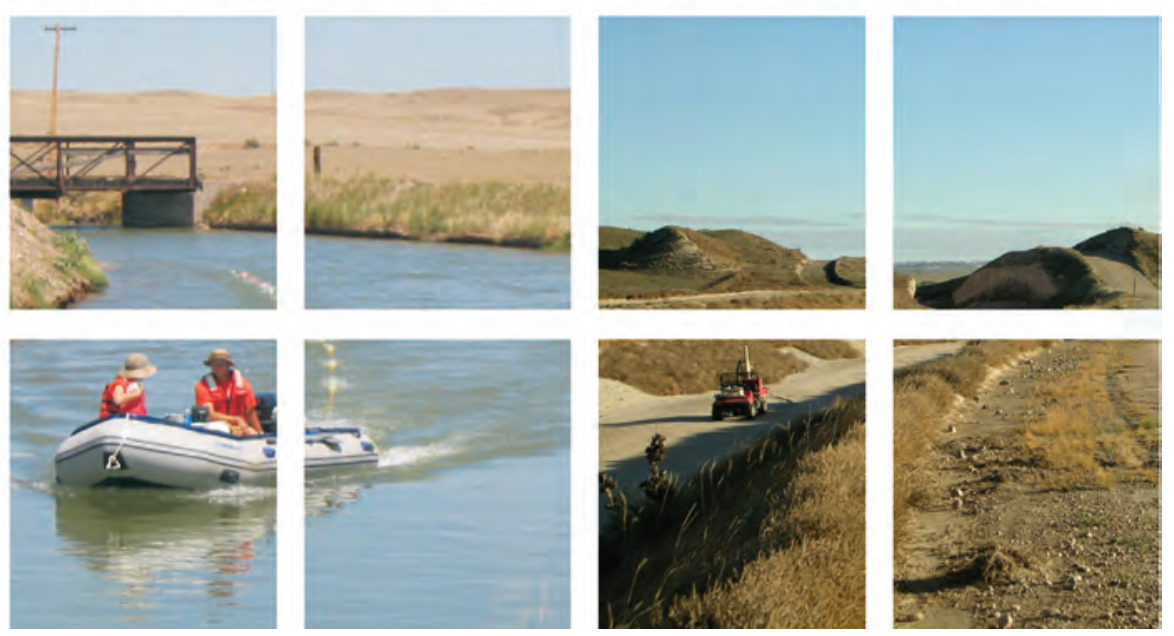
Front cover: Photographs showing (clockwise from top right) (1 and 2) the North Platte River Valley from Scottsbluff National Monument, (3) core sampling, Interstate Canal, (4) direct-current continuous resistivity profiling, and (5) cropland, Interstate Canal.

Back cover: Photographs showing (clockwise from top right) (1) capacitively coupled continuous resistivity profiling, Tri-State Canal, (2) the North Platte River Valley from Scottsbluff National Monument, (3) core sampling, Interstate Canal, (4) double rainbow, Interstate Canal, and (5) the North Platte River Valley and the city of Gering, Nebraska from Scottsbluff National Monument. 


\section{Determination of Canal Leakage Potential Using Continuous Resistivity Profiling Techniques, Interstate and Tri-State Canals, Western Nebraska and Eastern Wyoming, 2004}

By Lyndsay B. Ball, Wade H. Kress, Gregory V. Steele, James C. Cannia, and Michael J. Andersen

In Cooperation with the North Platte Natural Resources District

Scientific Investigations Report 2006-5032 


\section{U.S. Department of the Interior \\ P. Lynn Scarlett, Acting Secretary}

\section{U.S. Geological Survey \\ P. Patrick Leahy, Acting Director}

\section{U.S. Geological Survey, Reston, Virginia: 2006}

For product and ordering information:

World Wide Web: http://www.usgs.gov/pubprod

Telephone: 1-888-ASK-USGS

For more information on the USGS--the Federal source for science about the Earth, its natural and living resources, natural hazards, and the environment:

World Wide Web: http://www.usgs.gov

Telephone: 1-888-ASK-USGS

Any use of trade, product, or firm names is for descriptive purposes only and does not imply endorsement by the U.S. Government.

Although this report is in the public domain, permission must be secured from the individual copyright owners to reproduce any copyrighted materials contained within this report.

Suggested citation:

Ball, L.B.., Kress, W.H., Steele, G.V., Cannia, J.C., and Andersen, M.J., 2006, Determination of Canal Leakage Potential Using Continuous Resistivity Profiling Techniques, Interstate and Tri-State Canals, Western Nebraska and Eastern Wyoming, 2004: U.S. Geological Survey Scientific Investigations Report 2006-5032, 53 p. 


\section{Contents}

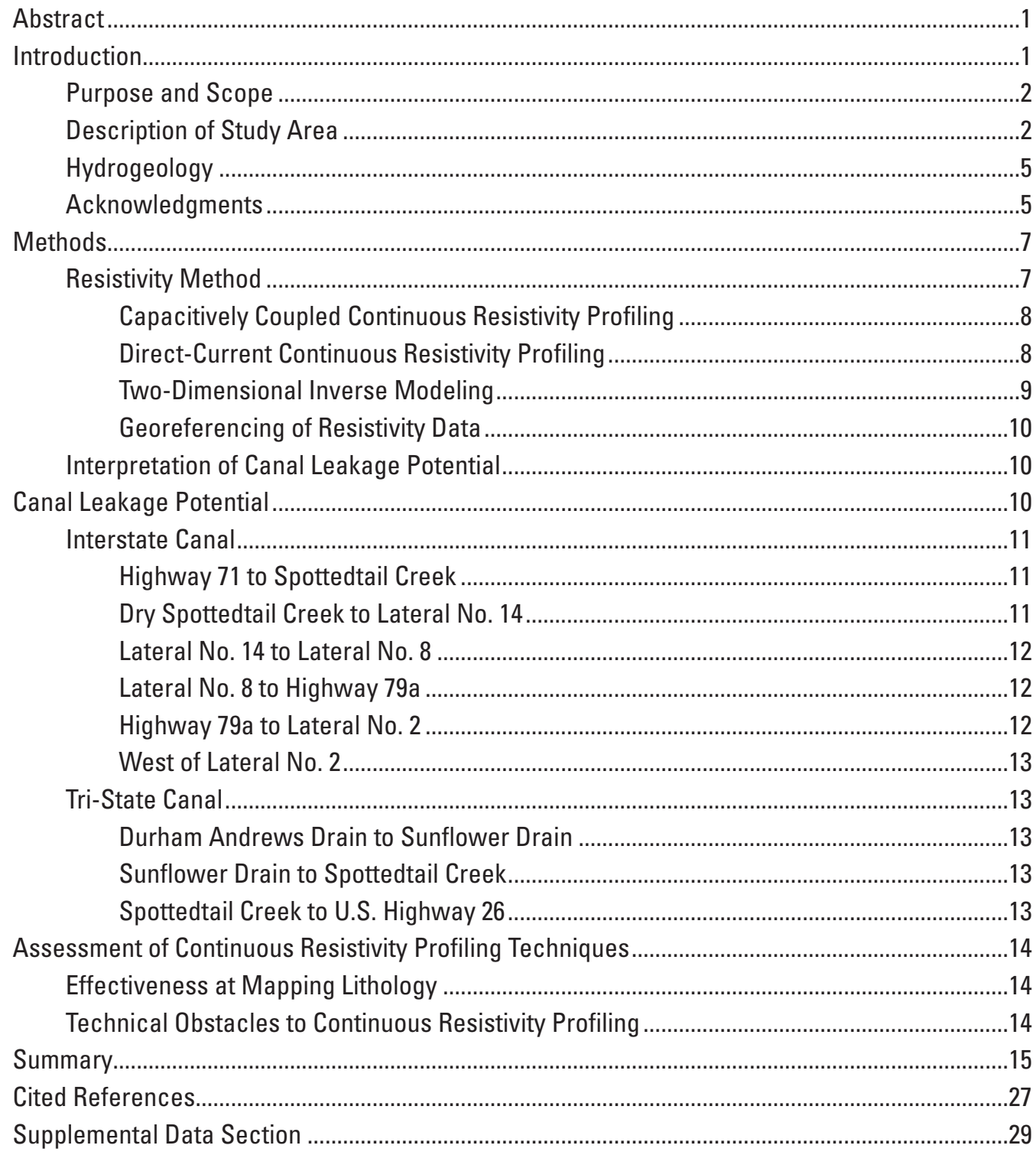

\section{Figures}

1a-1b. Maps showing:

1a. Location of the capacitively coupled resistivity survey...........................................

1b. Location of the direct-current resistivity survey.....................................................

2-3. Illustrations showing:

2. Capacitively coupled continuous resistivity profiling survey layout. .........................8

3. Direct-current continuous resistivity profiling survey layout...................................9 


\section{Figures-Continued}

28. Diagram showing legal description numbering system for test holes listed in table 3 .

29. Map showing potential for canal leakage from the Interstate and Tri-State Canals based on results from capacitively coupled and direct-current resistivity surveys.

30. Graph showing co-located water-borne direct-current resistivity sections collected in $\boldsymbol{A}$, June and August 2004 in the Interstate Canal, and $\boldsymbol{B}$, July and August in the Tri-State Canal.

4-27. Diagrams showing:

4. Comparison of $\boldsymbol{A}$, lithologic data from test hole 18 (TH18) drilled in the bed of the Interstate Canal, to $\boldsymbol{B}$, inverted capacitively coupled and direct-current resistivity sections and average resistivity curves.

5. Comparison of $\boldsymbol{A}$, lithologic data from test hole 25 (TH25) drilled in the bed of the Interstate Canal, to $\boldsymbol{B}$, inverted capacitively coupled and direct-current resistivity sections and average resistivity curves.

6. Comparison of $\boldsymbol{A}$, lithologic data from test hole 9 (TH9) drilled in the bed of the Interstate Canal, to $\boldsymbol{B}$, inverted capacitively coupled and direct-current resistivity sections and average resistivity curves.

7. Comparison of $\boldsymbol{A}$, lithologic data from test holes 22 and $22 \mathrm{~A}$ (TH22 and TH22A) drilled in the bed of the Interstate Canal, to $\boldsymbol{B}$, inverted capacitively coupled and direct-current resistivity sections and average resistivity curves.

8. Comparison of $\boldsymbol{A}$, lithologic data from test hole 4 (TH4) drilled in the bed of the Interstate Canal, to $\boldsymbol{B}$, inverted capacitively coupled and direct-current resistivity sections and average resistivity curves.

9. Comparison of $\boldsymbol{A}$, lithologic data from test hole $20 \mathrm{~A}$ (TH20A) drilled in the bed of the Interstate Canal, to $\boldsymbol{B}$, inverted capacitively coupled and direct-current resistivity sections and average resistivity curves.

10. Comparison of $\boldsymbol{A}$, lithologic data from test hole 26 (TH26) drilled in the bed of the Interstate Canal, to $\boldsymbol{B}$, inverted capacitively coupled and direct-current resistivity sections and average resistivity curves.

11. Comparison of $\boldsymbol{A}$, lithologic data from test hole 0 (THO) drilled in the bed of the Interstate Canal, to $\boldsymbol{B}$, inverted capacitively coupled and direct-current resistivity sections and average resistivity curves.

12. Comparison of $\boldsymbol{A}$, lithologic data from test hole 15 (TH15) drilled in the bed of the Interstate Canal, to $\boldsymbol{B}$, inverted capacitively coupled and direct-current resistivity sections and average resistivity curves.

13. Comparison of $\boldsymbol{A}$, lithologic data from test hole 12 (TH12) drilled in the bed of the Interstate Canal, to $\boldsymbol{B}$, inverted capacitively coupled and direct-current resistivity sections and average resistivity curves.

14. Comparison of $\boldsymbol{A}$, lithologic data from test hole $16 \mathrm{~A}$ (TH16A) drilled in the bed of the Interstate Canal, to $\boldsymbol{B}$, inverted capacitively coupled and direct-current resistivity sections and average resistivity curves.

15. Comparison of $\boldsymbol{A}$, lithologic data from test hole $11 \mathrm{~A}(\mathrm{TH} 11 \mathrm{~A})$ drilled in the bed of the Interstate Canal, to $\boldsymbol{B}$, inverted capacitively coupled and direct-current resistivity sections and average resistivity curves.

16. Comparison of $\boldsymbol{A}$, lithologic data from test hole 1 (TH1) drilled in the bed of the Interstate Canal, to $\boldsymbol{B}$, inverted capacitively coupled and direct-current resistivity sections and average resistivity curves. 


\section{Figures-Continued}

17. Comparison of $\boldsymbol{A}$, lithologic data from test hole 19 (TH19) drilled in the bed of the Interstate Canal, to $\boldsymbol{B}$, the inverted capacitively coupled section and direct-current resistivity curve.

18. Comparison of $\boldsymbol{A}$, lithologic data from test hole 5 (TH5) drilled in the bed of the Tri-State Canal, to $\boldsymbol{B}$, inverted capacitively coupled and direct-current resistivity sections and average resistivity curves.

19. Comparison of $\boldsymbol{A}$, lithologic data from test hole 17A (TH17A) drilled in the bed of the Tri-State Canal, to $\boldsymbol{B}$, inverted capacitively coupled and direct-current resistivity sections and average resistivity curves.

20. Comparison of $\boldsymbol{A}$, lithologic data from test hole 3 (TH3) drilled in the bed of the Tri-State Canal, to $\boldsymbol{B}$, inverted capacitively coupled and direct-current resistivity sections and average resistivity curves.

21. Comparison of $\boldsymbol{A}$, lithologic data from test hole 24 (TH24) drilled in the bed of the Tri-State Canal, to $\boldsymbol{B}$, inverted capacitively coupled and direct-current resistivity sections and average resistivity curves.

22. Comparison of $\boldsymbol{A}$, lithologic data from test hole 13 (TH13) drilled in the bed of the Tri-State Canal, to $\boldsymbol{B}$, inverted capacitively coupled and direct-current resistivity sections and average resistivity curves.

23. Comparison of $\boldsymbol{A}$, lithologic data from test hole 14 (TH14) drilled in the bed of the Tri-State Canal, to $\boldsymbol{B}$, inverted capacitively coupled and direct-current resistivity sections and average resistivity curves.

24. Comparison of $\boldsymbol{A}$, lithologic data from test hole 21 (TH21) drilled in the bed of the Tri-State Canal, to $\boldsymbol{B}$, inverted capacitively coupled and direct-current resistivity sections and average resistivity curves.

25. Comparison of $\boldsymbol{A}$, lithologic data from test hole 23 (TH23) drilled in the bed of the Tri-State Canal, to $\boldsymbol{B}$, inverted capacitively coupled and direct-current resistivity sections and average resistivity curves.

26. Comparison of $\boldsymbol{A}$, lithologic data from test hole 8 (TH8) drilled in the bed of the Tri-State Canal, to $\boldsymbol{B}$, inverted capacitively coupled and direct-current resistivity sections and average resistivity curves.

27. Comparison of $\boldsymbol{A}$, lithologic data from test hole 7 (TH7) drilled in the bed of the Tri-State Canal, to $\boldsymbol{B}$, inverted capacitively coupled and direct-current resistivity sections and average resistivity curves.

\section{Tables}

1. Principal hydrogeologic units in the study area, western Nebraska. .............................6

2. Field parameters used during continuous resistivity profiling..........................................8

3. Lithologic descriptions for test holes...........................................................................17 


\section{Conversion Factors and Datums}

\begin{tabular}{|c|c|c|}
\hline Multiply & By & To obtain \\
\hline \multicolumn{3}{|c|}{ Length } \\
\hline meter $(\mathrm{m})$ & 3.281 & foot $(\mathrm{ft})$ \\
\hline kilometer (km) & 0.6214 & mile (mi) \\
\hline kilometer (km) & 0.5400 & mile, nautical (nmi) \\
\hline meter $(\mathrm{m})$ & 1.0949 & yard $(y d)$ \\
\hline \multicolumn{3}{|c|}{ Area } \\
\hline square meter $\left(\mathrm{m}^{2}\right)$ & 0.0002471 & acre \\
\hline square kilometer $\left(\mathrm{km}^{2}\right)$ & 247.1 & acre \\
\hline square meter $\left(\mathrm{m}^{2}\right)$ & 10.76 & square foot $\left(\mathrm{ft}^{2}\right)$ \\
\hline square kilometer $\left(\mathrm{km}^{2}\right)$ & 0.3861 & square mile $\left(\mathrm{mi}^{2}\right)$ \\
\hline \multicolumn{3}{|c|}{ Resistivity } \\
\hline ohm-meter (ohm-m) & 3.281 & ohm-foot (ohm-ft) \\
\hline
\end{tabular}

Vertical coordinate information is referenced to the North American Vertical Datum of 1988 (NAVD 88).

Horizontal coordinate information is referenced to the North American Datum of 1983 (NAD 83).

Elevation, as used in this report, refers to distance above the vertical datum. 


\title{
Determination of Canal Leakage Potential Using Continuous Resistivity Profiling Techniques, Interstate and Tri-State Canals, Western Nebraska and Eastern Wyoming, 2004
}

\author{
By Lyndsay B. Ball', Wade H. Kress', Gregory V. Steele', James C. Cannia ${ }^{2}$, and Michael J. Andersen ${ }^{1}$
}

\section{Abstract}

In the North Platte River Basin, a ground-water model is being developed to evaluate the effectiveness of using water leakage from selected irrigation canal systems to enhance ground-water recharge. The U.S. Geological Survey, in cooperation with the North Platte Natural Resources District, used land-based capacitively coupled and water-borne direct-current continuous resistivity profiling techniques to map the lithology of the upper 8 meters and to interpret the relative canal leakage potential of 110 kilometers of the Interstate and Tri-State Canals in western Nebraska and eastern Wyoming. Lithologic descriptions from 25 test holes were used to evaluate the effectiveness of both techniques for indicating relative grain size. An interpretive color scale was developed that symbolizes contrasting resistivity features indicative of different grainsize categories. The color scale was applied to the vertically averaged resistivity and used to classify areas of the canals as having either high, moderate, or low canal leakage potential.

When results were compared with the lithologic descriptions, both land-based and water-borne continuous resistivity profiling techniques were determined to be effective at differentiating coarse-grained from fine-grained sediment. Both techniques were useful for producing independent, similar interpretations of canal leakage potential.

\section{Introduction}

The water supply of the North Platte River Basin in the Nebraska Panhandle has been designated as fully appropriated by the Nebraska Department of Natural Resources (DNR), and the entire alluvial valley floor, as well as some uplands, have been declared over-appropriated areas, meaning permitted water uses exceed the estimated water supply (North Platte

${ }^{1}$ U.S. Geological Survey

${ }^{2}$ North Platte Natural Resources District
Natural Resources District, 2004). The North Platte Natural Resources District (NRD) and the Nebraska DNR are developing an Integrated Management Plan (IMP) for water use in the North Platte NRD area. Necessary components of the IMP are a clear understanding of the ground-water and surface-water systems to be managed and the development of management tools that can be used by the participating agencies.

As part of the supporting work being done for the IMP, a ground-water-flow model is being developed to evaluate the effects of using water leakage from selected, unlined irrigation canals and laterals to enhance ground-water recharge. For the ground-water flow model to accurately simulate current or predict future conditions, specific inputs, such as the spatial distribution of canal leakage, are essential (Merry and others, 2003). However, canal leakage in a model often is estimated based on lithologic data from boreholes that may be several kilometers apart and not in the proximity of the canals. The estimation of model inputs using distant lithologic data may introduce potential errors in the ground-water-flow model.

The nature of the near-surface geology in the North Platte River Valley is highly variable. Previous drilling activities in the area have recorded grain sizes ranging from silt to coarse gravel and boulders above the local bedrock (Dreeszen and others, 2002). The surface of the bedrock has been incised by a number of shallow, narrow paleochannels, and a series of large, buried paleochannels that pass through the study area were described by Swinehart and others (1985). At the current land surface, many alluvial channels can be seen passing below the canals. These alluvial channels and buried paleochannels can contain various sediment types. Coarsegrained deposits can have substantially higher permeabilities (orders of magnitude) than fine-grained deposits, making them more amenable to the passage of water (Freeze and Cherry, 1979 , p. 29). Because highly permeable coarse-grained deposits typically convey more water than finer-grained deposits, canal sections underlain by coarse-grained sediment will typically leak more than canal sections underlain by finer-grained sediment (Driscoll, 1986). 
Lithologic information generally is collected by drilling test holes, which can be time-consuming and expensive. In addition, the lithologic data represents a single location, and lateral changes in grain-size distribution must be estimated between distant points. Surface geophysical methods, used in combination with strategic test drilling, provide more complete areal coverage than test drilling alone. Surface geophysical methods measure the physical properties of the subsurface, such as electrical conductivity (or its inverse, electrical resistivity), dielectric permittivity, magnetic permeability, density, or elasticity (Grant and West, 1965). These measurements can be influenced by chemical and physical properties of minerals, soil, rock, and pore fluids. Interpretations from these measurements can be used to estimate the distribution of physical properties in the subsurface.

Sediment displays a wide range of electrical resistivity values. For example, resistivity values for clay minerals can be less than $1 \mathrm{ohm}-\mathrm{m}$ (ohm-meter), whereas the resistivity of dry sand and gravel can exceed several thousand ohm-meters (Zohdy and others, 1974). In most near-surface rocks and sediments, electricity is conducted electrolytically through pore fluids, and the overall resistivity is controlled more by grain size, water content, and water quality than by the mineralogy of the matrix. Clay minerals, however, are capable of conducting electricity electronically through the exchange of cations. This causes the flow of current in clay to be both electronic and electrolytic, leading to a substantial decrease in the overall resistivity of the rock or sediment (Zohdy and others, 1974; Keller and Frischknecht, 1966). Because fine-grained sediments tend to contain more connected water and clay than coarse-grained sediments in partially saturated zones, finergrained sediments typically are less electrically resistive than coarser-grained sediments. Because of this contrast in electrical properties, resistivity techniques can be used to map the extent of coarse-grained and fine-grained deposits.

To provide information needed for the ground-water-flow model and to improve the general understanding of groundwater recharge in support of the IMP, the U.S. Geological Survey (USGS), in cooperation with the North Platte NRD, used continuous resistivity profiling techniques to map near-surface lithologies of the Interstate and Tri-State Canals in western Nebraska and eastern Wyoming. Test holes were then drilled at multiple locations in both canals to verify the results of the resistivity surveys, to compare the effectiveness of the two techniques, and to develop an interpretive scale that was used to estimate the relative canal leakage potential.

\section{Purpose and Scope}

This report presents the results of a surface geophysical investigation performed in 2004 in the North Platte River Valley to determine canal leakage potential. Both land-based capacitively coupled and water-borne direct-current continuous resistivity profiling techniques were used to map the relative grain size in the upper $8 \mathrm{~m}$ (meters) of selected parts of the Interstate and Tri-State Canals. Resistivity results were used in conjunction with lithologic descriptions from test holes drilled in the canal beds to create interpretive color scales for each technique that could be used to infer the relative canal leakage potential.

Capacitively coupled and direct-current resistivity data were compared to lithologic descriptions, and the overall effectiveness of each technique at mapping near-surface lithology was evaluated. This report also documents several technical obstacles unique to large-scale continuous resistivity profiling surveys that were encountered throughout data collection, processing, and interpretation.

\section{Description of Study Area}

The study area is located in the western part of the North Platte NRD in the Nebraska Panhandle, in Scotts Bluff and Sioux Counties and extending into Wyoming in Goshen County, and specifically within the Interstate and Tri-State Canals from approximately $10 \mathrm{~km}$ (kilometers) west of the Nebraska-Wyoming State line to about $4 \mathrm{~km}$ east of Scottsbluff, Nebraska (fig. 1). Alluvial and eolian sediments of Quaternary age vary in thickness across the majority of the area. The Brule Formation of Tertiary age, generally composed of siltstone and mudstone, crops out in the northern part of the study area and near the North Platte River along Highway 26 and serves as the predominant bedrock formation. The local terrain is characterized by riparian bottomlands, stream terraces, foot slopes, and uplands (Verstraeten and others, 2001).

Land cover near the canals is dominated by rangeland and cropland, with the major crops being irrigated corn, dry edible beans, sugar beets, and alfalfa (Verstraeten and others, 2001). Additional land uses in the study area are urban, including the communities of Scottsbluff, Mitchell, Morrill, and Henry (fig. 1), light industry, recreation, and livestock operations. Irrigation water is supplied predominantly from canals as surface water, although ground-water irrigation wells also are common. The Interstate and Tri-State Canals are the largest of several canals in the study area used to irrigate cropland, supporting approximately 47,400 and 20,300 hectares, respectively (Dennis Strauch, Pathfinder Irrigation District, written commun., November 14, 2005).

The Interstate Canal, operated by Pathfinder Irrigation District, begins diverting water from the North Platte River about $55 \mathrm{~km}$ west of the Wyoming-Nebraska State line and ends at its delivery point to the High Line Canal and Lake Alice, where additional diversions supply water to cropland and lakes east of the study area. The Interstate Canal intersects multiple outcrops of the Brule Formation, and typically is bordered by dry rangeland to the north and irrigated cropland to the south.

The Tri-State Canal, operated by Farmers Irrigation District, diverts water from the North Platte River about $10 \mathrm{~km}$ northwest of Morrill, Nebraska, and ends at its delivery point to North Port Irrigation District east of the study area. 


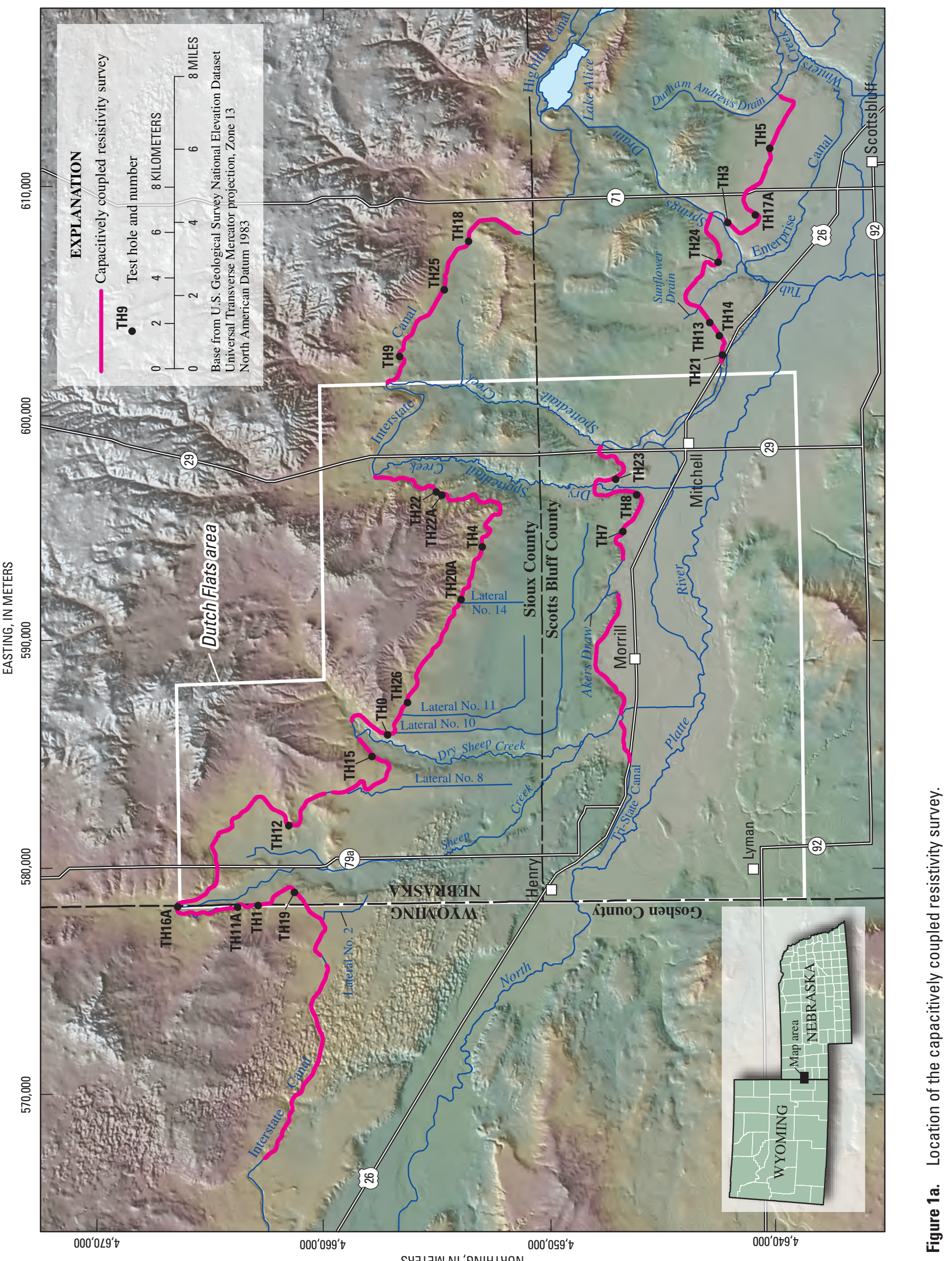




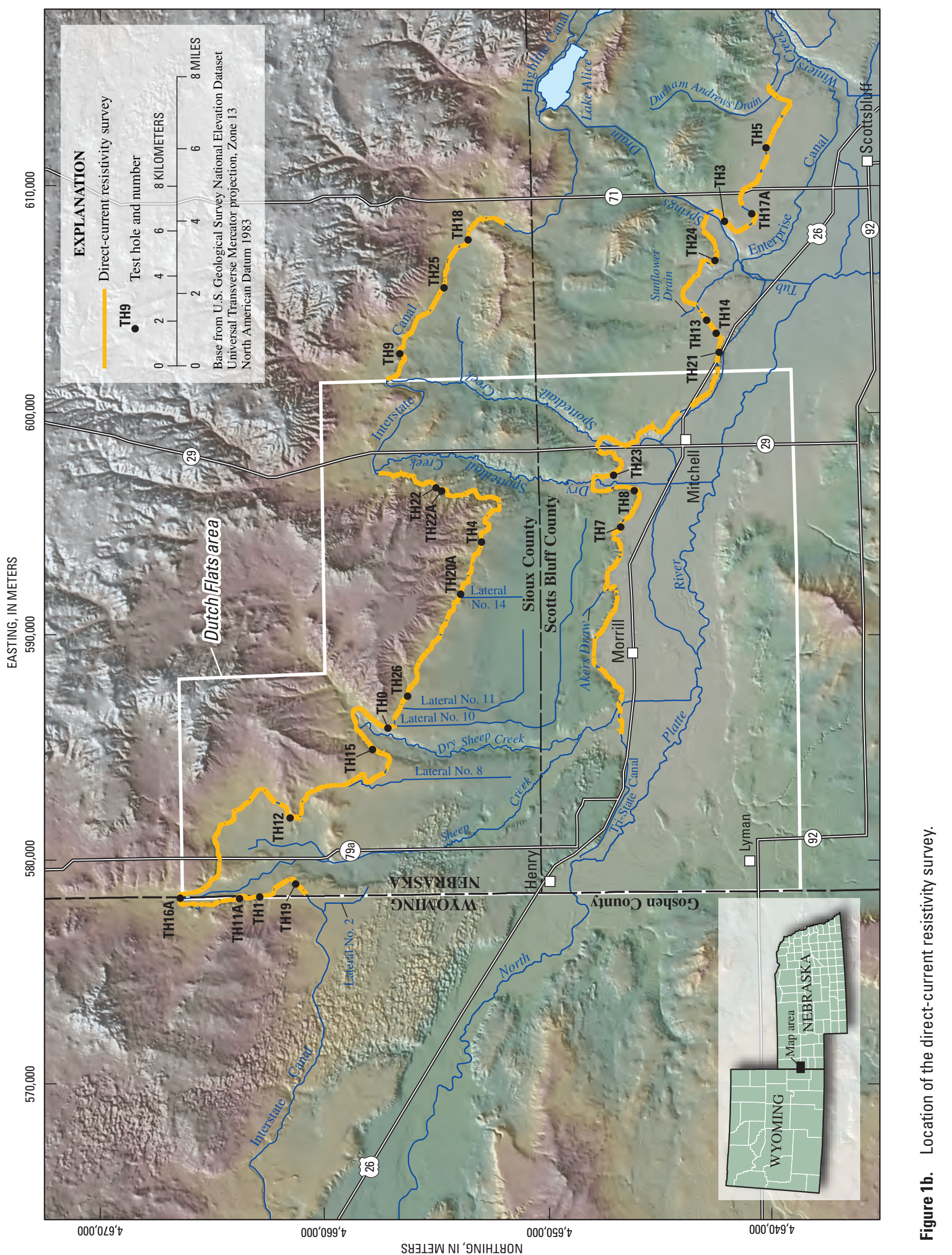


Irrigated cropland and dry rangeland are present on both sides of the canal. Several streams intersect the Tri-State Canal in the study area, including Sheep Creek, Dry Sheep Creek, Dry Spottedtail Creek, and Spottedtail Creek (fig. 1). Although some drainages pass below the canal, when the canal is not diverting water from the North Platte River, Akers Draw, Spottedtail Creek, and Tub Springs Drain discharge into the canal and flood its bottom. During the irrigation season, this surface water is captured and used for irrigation.

\section{Hydrogeology}

Previous investigators described the geology and occurrence of ground water in the study area (Darton, 1903a, 1903b; Wenzel and others, 1946; Babcock and Visher, 1951; Souders, 1986; Verstraeten and others, 1995; Verstraeten and others, 2001). Additional information, including a map showing the surficial geology along with geologic sections, and a more thorough discussion on the ground-water system of the Dutch Flats area are presented by Verstraeten and others (2001).

The shallowest ground-water system is the unconfined alluvial aquifer (table 1). In the Dutch Flats area, between the Tri-State and Interstate Canals north of the town of Morrill (fig. 1), Verstraeten and others (2001) divided the alluvial aquifer into a northern and southern component separated by a bedrock high formed by the Brule Formation. The bedrock high separates the paleochannels of the ancestral North Platte River Valley north of the bedrock high (the upland) from the present North Platte River Valley (the bottomland). The bedrock high, which separates the northern and southern aquifers, runs parallel to the North Platte River and generally is just north of the Tri-State Canal. The valley wall provides a distinguishable topographic relief of as much as $30 \mathrm{~m}$.

In the northern aquifer, the water table typically is between $1.5 \mathrm{~m}$ to $25 \mathrm{~m}$ below the land surface. In the southern aquifer, the water table typically is less than $6 \mathrm{~m}$ below the land surface, and when the Tri-State Canal operates, the water table can be near or at the land surface (Verstraeten and others, 2001). The saturated thickness of the alluvial aquifer in the study area varies from less than $1.5 \mathrm{~m}$ near the valley walls to more than $60 \mathrm{~m}$ near the present day North Platte River.

Ground-water movement in the study area generally is toward the North Platte River or its tributaries (Verstraeten and others, 2001). In the northern alluvial aquifer, partial local obstructions of ground-water movement by the bedrock high causes ground-water movement to deviate from the predominant north-south direction of flow. In the part of the southern alluvial aquifer north of the North Platte River, ground water moves predominantly from north to south from areas recharged by ground water from the northern alluvial aquifer toward the North Platte River.

Recharge to the northern and southern alluvial aquifers in the study area predominantly is from irrigation canals (Babcock and Visher, 1951; Verstraeten and others, 2001). The two primary canals in the study area, the Interstate and
Tri-State Canals, contribute substantial amounts of recharge to the alluvial aquifers, and this recharge eventually reaches the North Platte River. Verstraeten and others (2001) reported that water moving downward through canal beds affects the movement of ground water by increasing the hydraulic head in the aquifer near the canals. As the ground-water hydraulic head near the canal increases, the overall gradient of the system also increases and ground water moves from areas near the canals to the discharge areas. Most monitoring wells in the study area experience water-level rises during the irrigation season and declines after the canals empty. A more thorough discussion on the surface-water/ground-water interaction is presented by Verstraeten and others (2001).

\section{Acknowledgments}

The authors acknowledge and extend special appreciation to Dennis Strauch, manager of the Pathfinder Irrigation District, for his continuous support during data collection efforts. Thanks also are extended to the Pathfinder and Farmers Irrigation Districts for allowing unlimited access to their canal systems. Special appreciation is extended to Jared Abraham, USGS, for lending his insight and expertise to the interpretation of resistivity data. Special appreciation is also extended to Richard Luckey, USGS, for his contribution to the development of this report. The authors also extend special thanks to Chris Jutting, North Platte NRD, and Jim Rauman, USGS, for their assistance during core sampling. Thanks also are extended to Jennifer Carpenter, USGS, for her assistance with lithologic descriptions. Appreciation also is extended to Andrew Teeple and Suzanne Roberts, USGS, who provided support for the development of tables and figures in this report. 


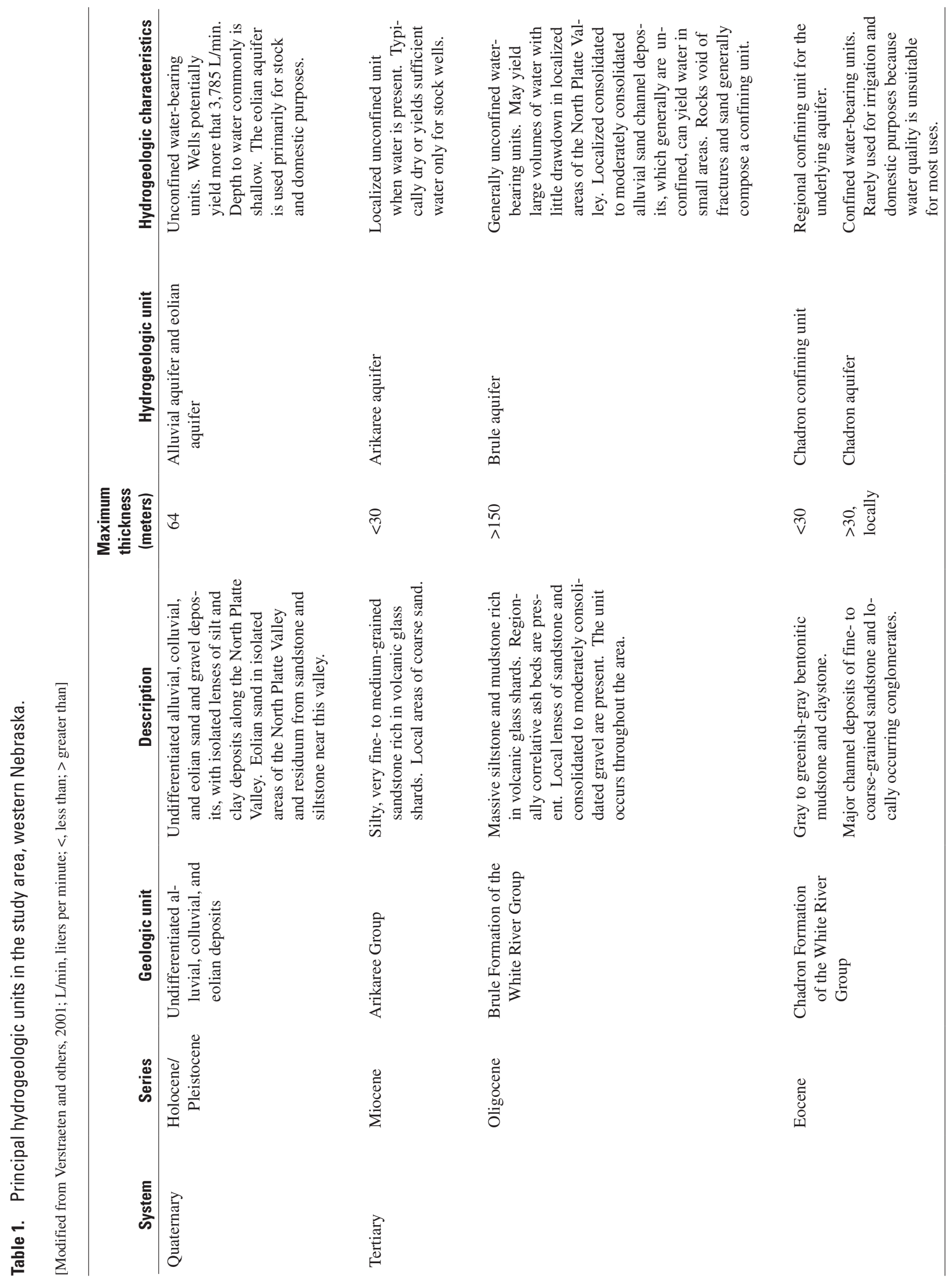




\section{Methods}

Capacitively coupled (CC) and direct-current (DC) resistivity data were collected over approximately $110 \mathrm{~km}$ (68 miles) of the Interstate and Tri-State Canals in Sioux and Scotts Bluff Counties (fig. 1) during the spring and summer of 2004. Before water delivery began in the canals, CC resistivity data were collected using a land-based continuous resistivity profiling (CRP) technique. CC resistivity data were not collected in some parts of the canals because of the flooded conditions caused by streams that flow into the Tri-State Canal, or because of the proximity to obstructions, such as siphons and control structures. The Interstate Canal began diverting water from the North Platte River on May 25 (Dennis Strauch, Pathfinder Irrigation District, oral commun., June 30, 2005), and the Tri-State Canal began diverting water from the North Platte River on July 3 (Kevin Adams, Farmers Irrigation District, oral commun., June 29, 2005). Shortly after the beginning of water delivery, DC resistivity data were collected using a water-borne CRP technique. DC resistivity data were not collected in some parts of the canals because of the proximity to obstructions, such as siphons, control structures, and low bridges.

Test holes were drilled at 20 random locations and 5 selected locations in the bottom of the canals in November 2004, to provide control data for the resistivity results and to determine the effectiveness of each CRP technique in mapping near-surface lithology (fig. 1). Random locations were selected by compiling a table of the shared coordinates of both the CC and DC resistivity surveys, assigning a randomly generated number to each coordinate, and selecting the first 20 locations. The resistivity sections were examined near each random test-hole location, and 5 additional test-hole locations were selected to ensure repeated sampling of all major types of resistivity features. At each test-hole location, continuous core samples were collected from the dry canal bed using a Geoprobe direct-push system. Detailed, qualitative lithologic data were continuously described at each test hole from the core samples.

The CC and DC resistivity data were processed, interpreted, and georeferenced to create a three-dimensional database for each technique. The databases allowed for an accurate and efficient comparison of CC and DC resistivity data and provided the ability to directly compare lithologic data from test holes to the resistivity data. The databases also facilitated the consistent interpretation of resistivity data, in which resistivity data near test holes were simultaneously compared to lithologic information, and unique interpretive color scales were developed for each resistivity technique. These scales were then applied to resistivity data between test holes, allowing canal leakage potential to be interpreted for the entire study area.

\section{Resistivity Method}

Resistivity measurements are made by transmitting current into the subsurface and measuring the resulting voltage at the ground surface. The resistance, $R$, is then calculated by dividing the measured voltage by the transmitted current, as described by Ohm's Law (Zohdy and others, 1974):

$$
R=\Delta V / I
$$

Where $\Delta V$ represents the potential difference measured by the potential electrodes and $I$ represents the current applied through the current electrodes. The apparent resistivity of the subsurface is calculated by multiplying each resistance by a geometric factor determined by the geometry and the spacing of the electrode array (Zohdy and others, 1974). By increasing the distance between electrodes, deeper apparent resistivity measurements can be obtained. The resistivity technique is described in detail by Grant and West (1965) and Zohdy and others (1974).

Resistivity data can be collected using different techniques. Traditionally, individual resistivity measurements are made by using a set of four electrodes (two current electrodes and two potential electrodes), known as an array, to make a measurement. The central point of the array is kept at the same location and the electrode spacing is increased to obtain measurements at increasing depths, a technique known as resistivity sounding. The central point of the array is then moved, and the process repeated until the desired area is covered. An alternative to resistivity sounding is resistivity profiling, in which a large number of electrodes are connected to a multiconductor cable and controlled by an automatically switching resistivity meter. The resistivity meter uses an initial set of four electrodes (two current electrodes and two potential electrodes) to make a measurement, switches to another four electrodes, and then continues until all electrodes have been used in a sequence of different spacings to create a two-dimensional (2-D) section of apparent resistivity.

Advanced resistivity meters allow multiple measurements to be made simultaneously. Multiple data channels are used to measure the voltages between potential electrodes with various spacings using a single current transmission from two current electrodes. Therefore, the apparent resistivity at multiple depth intervals can be determined simultaneously, and data can be collected while the array is slowly pulled using the CRP technique. CRP allows rapid collection of resistivity data with high horizontal resolution. 


\section{Capacitively Coupled Continuous Resistivity Profiling}

Four antennas are required to make a $\mathrm{CC}$ resistivity measurement: two antennas are for the transmitter and two are for the receiver. The transmitter generates a known current which induces current flow in the subsurface through capacitance, using an alternating current at a fixed frequency, and the receiver measures the resultant voltage. Resistance is calculated using Ohm's Law and is converted to apparent resistivity by applying the appropriate geometric correction factor (Zohdy and others, 1974).

The depth of investigation can be altered by increasing the separation distance between the transmitter and the receiver, similar to the changing of electrode spacing in more traditional resistivity measurements. By using multiple receivers simultaneously with a single transmitter, data at different depth intervals can be collected simultaneously, allowing a vertical resistivity profile to be collected with a single current transmission. Because the electrical relation with the ground is developed through capacitance, electrical contact can be achieved without driving electrodes into the subsurface. Therefore, measurements can be made while an array is pulled slowly along the ground surface, allowing the more efficient CRP technique to be used.

$\mathrm{CC}$ resistivity data were collected over about $110 \mathrm{~km}$ of the Interstate and Tri-State Canals during 6 days in late April 2004 (fig. 1A) prior to the start of the irrigation season. The $\mathrm{CC}$ resistivity survey was performed with the Geometrics OhmMapper TR-5, a CC resistivity meter with one transmit- ter and five receivers. The TR-5 was towed across the bed of the center of both canals with an all-terrain vehicle (ATV) (fig. 2). Array details are described in table 2. A differentially corrected global positioning system (GPS) was used to collect geospatial data during the resistivity survey. Magmap2000 version 4.56 (Geometrics, 2004) was used for initial processing, and data were then exported for further processing and inversion.

Table 2. Field parameters used during continuous resistivity profiling.

\begin{tabular}{lll}
\hline \multicolumn{1}{c}{ Property } & \multicolumn{1}{c}{$\begin{array}{c}\text { Capacitively } \\
\text { coupled resistivity }\end{array}$} & \multicolumn{1}{c}{$\begin{array}{c}\text { Direct-current } \\
\text { resistivity }\end{array}$} \\
\hline Array type & Dipole-dipole & Dipole-dipole \\
Dipole length (a) & 10 meters & 3 meters \\
Dipole separation & $0.25,0.75,1.25$, & $1,2,3,4,5,6,7,8$, \\
factor (n) & $1.75,2.25$ & 9,10 \\
Approximate depth & 8 meters & 8 meters \\
of investigation & & \\
\hline
\end{tabular}

\section{Direct-Current Continuous Resistivity Profiling}

Four electrodes are required to make a DC resistivity measurement: two current electrodes and two potential electrodes. A known current is transmitted through the current electrodes, and the resulting voltage is measured between the potential electrodes. Resistance is calculated using Ohm's Law

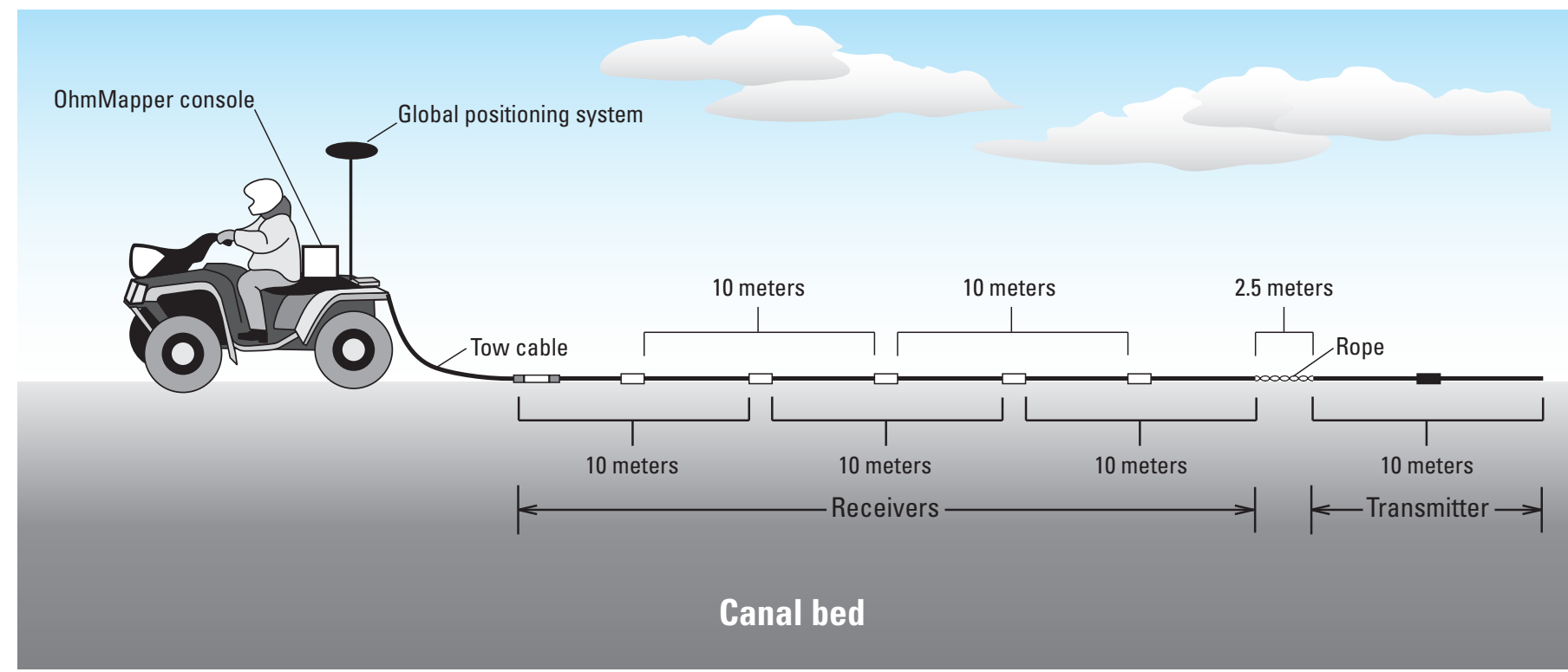

Not to scale

EXPLANATION

Optical wand and weight

$\square$ Receiver unit

- Transmitter unit

Figure 2. Capacitively coupled continuous resistivity profiling survey layout. 
and converted to apparent resistivity by applying the appropriate geometric correction factor (Zohdy and others, 1974).

Using multiple channels in the resistivity meter, multiple potential electrode pairs can be used simultaneously with a single current electrode pair. This allows a vertical resistivity profile to be collected using a single current transmission. By deploying the electrodes in water, electrical contact can be maintained without driving electrodes into the subsurface, and data can be collected while the array is pulled slowly using the CRP technique. A floating array is pulled at a relatively constant speed, continuously collecting data. Water-borne CRP eliminates the need for extensive electrode installation and reduces the time required to survey large areas.

Water-borne DC resistivity data were collected during 3 days beginning on June 14, 2004, over $55 \mathrm{~km}$ of the Interstate Canal and during 4 days beginning on July 12, 2004, over $45 \mathrm{~km}$ of the Tri-State Canal (fig. 1B), both within the first 3 weeks of the irrigation season. Data collection was repeated in both canals during 6 days in August 2004, toward the end of irrigation season. Data were collected using the IRIS Instruments Syscal Pro 10-channel resistivity meter. A water-proof multiconductor cable with graphite electrodes was towed upstream in the canals using a floating dipole-dipole array, with 2 current electrodes directly behind the boat followed by 11 potential electrodes, resulting in 10 measurements for every current transmission (fig. 3). Array details are described in table 2. A differentially corrected GPS was used to collect real-time position information during data collection. A depth sounder was used in conjunction with the GPS to collect water depth information. DC resistivity data were initially processed using Prosys version 09.05.00 (IRIS Instruments, 2003) and were exported for further processing and inversion.

\section{Two-Dimensional Inverse Modeling}

Apparent resistivity, as calculated from the field measurements, is the electrical resistivity over an equivalent electrically homogeneous and isotropic subsurface, and is used to represent the average resistivity of a more realistic, heterogeneous subsurface (Loke, 2000). To help determine the "true" distribution of electrical resistivity in the subsurface, an inversion program develops a 2-D model consisting of rectangular blocks of individual resistivity values. The inversion program then determines the calculated system response over that model, referred to as the "calculated apparent resistivity," based on the field data-collection parameters. These parameters include the type of array utilized, the distance between electrodes, and the number of measurements taken. The root mean square (RMS) difference between the measured and calculated apparent resistivities is used to determine the accuracy of the model. The inversion program then attempts to reduce the RMS difference by altering the model resistivity values and recalculating the apparent resistivity; this alteration is known as an "iteration." When the RMS difference between the calculated and measured apparent resistivity no longer improves more than one percent between iterations, a solution is reached. This final model represents a non-unique estimate of the "true" 2-D distribution of electrical resistivity within the subsurface. This inversion process is described in detail by Loke (2004).

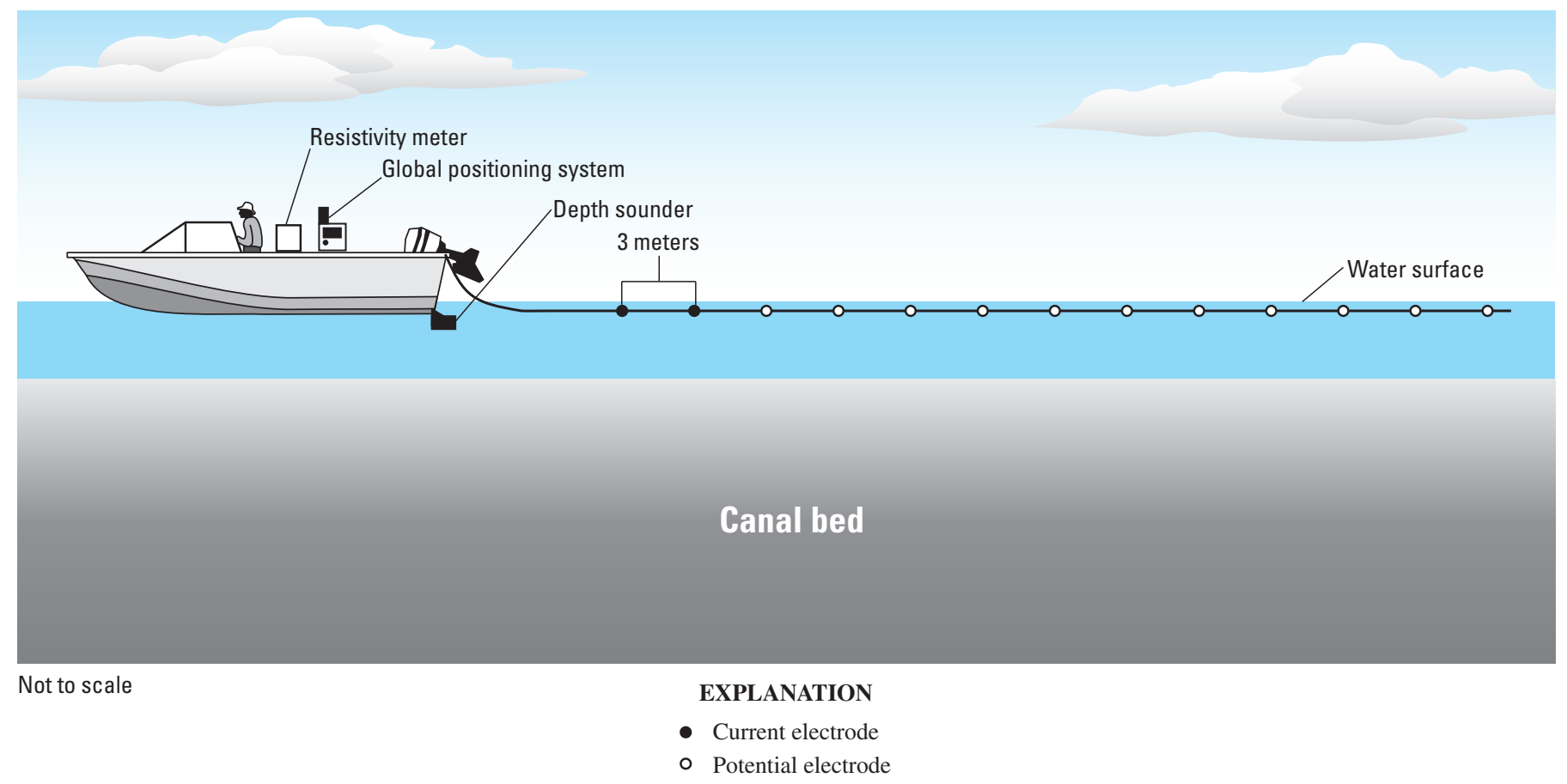

Figure 3. Direct-current continuous resistivity profiling survey layout. 
Both CC and DC resistivity data were inverted using the finite-element method with the least-squares approximation using RES2DINV version 3.54w (Loke, 2004). Because RES2DINV requires 2-D sections, all data were assumed to be collected in straight lines, although the canal is somewhat sinuous within individual sections. Because the geometric factor used to calculate apparent resistivity is dependent on maintaining a consistent length between electrodes, and the array pulled behind the boat or ATV was able to remain relatively straight throughout data collection, these calculations are considered correct and the inversion process was considered to be valid for the majority of sections.

\section{Georeferencing of Resistivity Data}

The CC and DC resistivity data were processed, inverted, and georeferenced to create a three-dimensional database for each resistivity technique. A procedure was developed to convert the individual, local coordinate systems of the inverted resistivity sections to georeferenced coordinates on a sectionby-section basis. The original GPS-derived latitude and longitude coordinates were compiled into a line, and that line was divided into the same number of points as there were model cells in the final inverted resistivity model section. Latitude and longitude coordinates were then converted to projected Universal Transverse Mercator coordinates and were joined to the inverted resistivity value and depth from the corresponding model cell. These georeferenced resistivity data were compiled into databases, allowing for an accurate and efficient comparison of CC and DC resistivity data and providing the ability to directly compare lithologic data from test holes with the resistivity data.

\section{Interpretation of Canal Leakage Potential}

Results from analyzing resistivity profiles were used to interpret the potential for canal leakage throughout the study area. The inverted resistivity sections near test holes were evaluated, and two interpretive color scales-one for each resistivity technique-were created that correspond to the relation between resistivity and the relative grain size of unconsolidated sediment. The color scales were modified iteratively, were applied to the selected inverted resistivity sections, and the results were compared to test-hole lithology until scales were obtained that most reasonably represented the lithologic descriptions.

Although substantial variations in resistivity existed laterally, resistivity values at each measurement point typically were uniform vertically within the depth of investigation for this study. Because of this vertical consistency, a single value was used to represent a single geographic coordinate. The arithmetic average was taken of the inverted resistivity values for the vertical column of model cells corresponding to each geographic coordinate. In the inversion model, model cells increased in thickness by 10 percent with each depth level, causing the average resistivity calculation to be more heavily weighted towards the surface. This was considered to be a more useful representation of the subsurface than a linear average for the sections where resistivity did change with depth, because it was assumed that leakage is predominantly controlled by the sediments directly underlying the canal bed. To minimize the effect of the water column on the average DC resistivity, the cells in the upper $2.5 \mathrm{~m}$ of the inverted resistivity section were not used in the calculation of the average resistivity, although they were included in the inversion process. The same color scales developed for each technique during the profile analysis were then applied to the average resistivity, and the accuracy of these scales were reevaluated by comparing them with the lithologic logs. The two color scales were revised until the interpretation of vertically averaged resistivity from each technique corresponded to the relative grain size of the sediment.

\section{Canal Leakage Potential}

$\mathrm{CC}$ and DC resistivity data were collected in the spring and summer of 2004 in selected sections of the Interstate and Tri-State Canals (fig. 1). Although resistivity data distribution was mostly continuous, $\mathrm{CC}$ resistivity data could not be collected in three sections of the Tri-State Canal because of flooding from the intersections of Tub Springs Drain, Spottedtail Creek, and Akers Draw. CC and DC resistivity data could not be collected from other small sections because of proximity to control structures, low bridges, and siphons.

Resistivity data were processed and inverse modeling was used to develop a possible interpretation of the "true" resistivity of the subsurface. The inverted resistivity sections of both $\mathrm{CC}$ and DC resistivity data near test holes were georeferenced based on the original GPS data collected during field surveys. Data from each technique were then compiled into databases for interpretation. Figures 4 through 27 (in Supplemental Data Section in the back of this report) show profiles of selected inverted resistivity sections of both $\mathrm{CC}$ and DC resistivity data near test holes. These profiles are presented in order from downstream to upstream, first for the Interstate Canal and then for the Tri-State Canal. Depth is displayed in meters below the bottom of the canal in both the CC and DC profiles. For the DC resistivity data, an average water depth of $2.5 \mathrm{~m}$ was used, and 0 references the bottom of the canal. This causes the depth of the resistivity sections to be approximately 4 to $6 \mathrm{~m}$ below the canal, instead of the $8 \mathrm{~m}$ seen in the $\mathrm{CC}$ resistivity data. These profiles were compared to each other and to the qualitative lithologic descriptions of the continuous core samples (table 3, fig. 28).

During the profile comparison, two interpretive color scales were developed separately for CC and DC resistivity results because of the substantial difference in resistivity values between the two techniques; however, sufficient contrasts were consistently found in both CRP techniques to indicate 
differences in relative grain-size. Low resistivity features typically were associated with well-sorted, very fine sand and silt, and the siltstone of the Brule Formation, and are represented as light and dark blue. Moderate resistivity features typically were associated with moderately to well-sorted fine and medium sand with some occasional coarser sand and are represented by green and yellow. High resistivity features typically were associated with coarse sand and poorly sorted sediments containing gravel, and are represented by orange and red.

The final color scale for each technique, when applied to the corresponding average resistivity, was interpreted to be an accurate representation of the relative canal leakage potential (fig. 29). Red and orange areas represent high average resistivity areas that were associated with coarse-grained sediments such as coarse or mixed sand and gravel; yellow and green areas represent moderate resistivity features that were found to be associated with moderately to well-sorted medium and fine sand; and blue areas represent low resistivity features that were found to be associated with fine-grained sediments such as well-sorted, very fine sand and silt, as well as the siltstone of the Brule Formation. Typically, coarse-grained alluvial sediments possessed higher average resistivity values than that of fine-grained sediments and consolidated rocks. Because of the relation between the average resistivity and relative grain size, the average resistivity was considered to be directly proportional to the canal leakage potential, and could be used to estimate the spatial distribution of canal leakage throughout the study area.

Because of the similar features found in the selected inverted resistivity sections and the correlation of both techniques to the lithologic logs, it was determined that either technique could be used to develop a similar interpretation of canal leakage potential. The $\mathrm{CC}$ resistivity data were selected to represent the majority of the study area because of the greater overall area covered by the $\mathrm{CC}$ resistivity survey (fig. 1), the greater depth of investigation below the bed of the canals compared to the DC resistivity data, and because the data displayed a wider range of resistivities than the DC resistivity data (figs. 4-27). All CC resistivity data were georeferenced, and the final color scale, developed using the selected inverted resistivity sections near test-hole locations, was applied to the full final database (fig. 29). Additional sections of the DC resistivity data collected in July 2004 were georeferenced and compiled into a database to provide data coverage in the sections of the Tri-State Canal that were flooded during the $\mathrm{CC}$ resistivity survey (fig. 29).

\section{Interstate Canal}

Both CC and DC resistivity sections were compared to lithologic logs (table 3). After an interpretive color scale was developed based on this analysis, the average resistivity of the $\mathrm{CC}$ resistivity data was used to develop interpretations of the comparative canal leakage potential (fig. 29). DC resistivity data were not used to interpret canal leakage potential for the Interstate Canal because of the greater coverage of the $\mathrm{CC}$ resistivity survey.

A wide range of canal leakage potential values was found throughout the Interstate Canal (fig. 29). The highest canal leakage potential in the Interstate Canal was found west of the Wyoming-Nebraska State line. Moderately high to moderate canal leakage potential was found between Lateral No. 14 and about $2 \mathrm{~km}$ north of Lateral No. 8, as well as between about $600 \mathrm{~m}$ west of Highway 79a and Lateral No. 2. Between Dry Spottedtail Creek and Lateral No. 14, a wide variety of leakage potentials were found, including high leakage potential where at least one alluvial channel was found, moderate leakage potential that dominated the $3 \mathrm{~km}$ directly southwest of Dry Spottedtail Creek, and low leakage potential in areas where the Brule Formation outcropped. Low canal leakage potential was found between Highway 71 and Spottedtail Creek, as well as between about $2 \mathrm{~km}$ north of Lateral No. 8 and about $600 \mathrm{~m}$ west of Highway 79a. The Brule Formation was within the depth of investigation in both of these areas of the Interstate Canal.

\section{Highway 71 to Spottedtail Creek}

The eastern surveyed part of the Interstate Canal, between Highway 71 and Spottedtail Creek, generally showed low average resistivity. Test hole (TH) 18 (fig. 4; table 3) and TH9 (fig. 6; table 3) had tightly packed, very fine sand or weathered siltstone indicative of the Brule Formation, and both holes reached drilling refusal (Geoprobe could not be pushed deeper) before completing the full 9-m depth of investigation. TH25 (fig. 5) was drilled to the full investigation depth and contained very fine silty sand, silt, and silty clay, although some siltstone fragments appeared below $7 \mathrm{~m}$ (table 3). CC and DC resistivity sections near TH18 and TH9 showed mostly low-resistivity features, whereas resistivity sections near $\mathrm{TH} 25$ showed a combination of moderate- to low-resistivity features. The tightly packed, fine-grained sediments found at the test holes support the conclusion that these low average resistivity values are indicative of low canal leakage potential (fig. 29).

\section{Dry Spottedtail Creek to Lateral No. 14}

The part of the Interstate Canal between Lateral No. 14 and Dry Spottedtail Creek showed a wide range of resistivity features. The northeastern $3 \mathrm{~km}$ of this area showed moderate average resistivity, whereas the western length of this part of the canal showed a combination of high and moderate average resistivity values. A length of about $1 \mathrm{~km}$ separated these two areas and contained low average resistivity values interlaced with high average resistivity values. TH22 and TH22A (fig. 7) were within this 1-km length and showed these high- and low-resistivity features. Siltstone cropped out at the surface, and at the location of the high-resistivity feature, a dry alluvial 
channel was found cutting through siltstone on both sides of the canal. TH22 contained sand and gravel and reached weathered siltstone at a depth of $5.2 \mathrm{~m}$ (table 3 ). TH22A, about $300 \mathrm{~m}$ southwest of TH22, was in a low-resistivity part of the canal and siltstone was reached at $0.3 \mathrm{~m}$.

TH4 (fig. 8) was in a small section of moderate average resistivity in the western length of this part of the canal, and contained sand and gravel, poorly sorted sand, and two layers of moderately to well-sorted medium to fine sand (table 3 ). The CC resistivity section near this test hole contained moderate- to moderately high-resistivity features, whereas the DC resistivity section showed more high-resistivity features below the water column. The sand and gravel layers seen in TH4 usually would be associated with higher-resistivity features than expressed in the $\mathrm{CC}$ resistivity section at this location. More than one-half of the total depth of investigation was composed of moderately to well-sorted sand layers. These layers could be reducing the resistivity of the $\mathrm{CC}$ section. Because these moderately to well-sorted sand layers could be less susceptible to leakage than continuous sand and gravel, the moderate average resistivity and canal leakage potential were considered to be reasonable for this location.

TH20A (fig. 9) was in a high average resistivity area about $200 \mathrm{~m}$ southeast of Lateral No. 14. The test hole contained sand and gravel and moderately sorted mixed sand until a depth of $4.6 \mathrm{~m}$, where dense silt and fine sand associated with a weathered part of the Brule Formation were found, and drilling refusal was met at $5.1 \mathrm{~m}$ (table 3 ). The $\mathrm{CC}$ resistivity section at TH20A showed high-resistivity features in the upper $4 \mathrm{~m}$ of the section. The decreased resistivity at depth was most likely caused by the transition from sand and gravel to weathered siltstone. The DC resistivity section showed only the high-resistivity feature associated with the sand and gravel layer, and the depth of investigation ended just before reaching a depth of $5 \mathrm{~m}$.

\section{Lateral No. 14 to Lateral No. 8}

The part of the Interstate Canal between Lateral No. 14 and about $2 \mathrm{~km}$ north of Lateral No. 8 was dominated by moderate average resistivities. TH26 (fig. 10) was in a moderate average resistivity area that was representative of the nearly 6-km stretch of the canal between Lateral No. 14 and Lateral No. 11. TH26 contained moderately to well-sorted very fine sand, with some small lenses of coarser sand fragments (table 3). Both CC and DC resistivity sections near this location showed continuous moderate-resistivity features. TH0 (fig. 11), in a moderately high average resistivity area, contained fine to medium sand with some gravel fragments mixed with coarser sand and gravel (table 3). TH15 (fig. 12) had moderate-resistivity features and contained mostly wellsorted, very fine and fine sands, with a thin $(0.4 \mathrm{~m})$ band of coarse gravel near the 3-m depth (table 3). TH26 and TH15 were both dominated by fine-grained sediments and were both characterized by similar resistivity sections, whereas THO contained coarse-grained sediments and had a higher resistiv- ity section than the surrounding area, making the higher canal leakage potential surrounding $\mathrm{TH} 0$ a reasonable interpretation (fig. 29).

\section{Lateral No. 8 to Highway 79a}

The part of the Interstate Canal between $2 \mathrm{~km}$ north of Lateral No. 8 and 600 m west of Highway 79a had low average resistivity values. TH12 (fig. 13) mostly contained tightly packed silt and fine sand with some siltstone fragments until drilling refusal was met at $3.4 \mathrm{~m}$ (table 3), probably indicating Brule Formation below that depth. In the CC resistivity data section, the initially moderate resistivity decreased below a depth of $4 \mathrm{~m}$, supporting the change in lithology indicated by drilling refusal. The DC resistivity section also showed low-resistivity features. The tightly packed material found in this test hole is consistent with the low canal leakage potential (fig. 29).

\section{Highway 79a to Lateral No. 2}

The part of the Interstate Canal between about $600 \mathrm{~m}$ west of Highway 79a and Lateral No. 2 was dominated by moderate average resistivity values. TH16A (fig. 14), in an area with moderate average resistivity, contained sand and gravel to a depth of $2.7 \mathrm{~m}$ and silty fine sand with siltstone fragments to a depth of $3.2 \mathrm{~m}$, where siltstone was found and drilling refusal occurred (table 3 ). The $\mathrm{CC}$ resistivity section at this location indicated a moderately high- to moderateresistivity layer above $4 \mathrm{~m}$, and a low-resistivity layer below $4 \mathrm{~m}$. TH11A (fig. 15), also in a moderate average resistivity area, contained mostly well-sorted silt, fine sand, and sand. Coarse sand and gravel layers occurred between $4.6 \mathrm{~m}$ and $7.3 \mathrm{~m}$, and siltstone was found at $7.9 \mathrm{~m}$ (table 3). Both CC and DC resistivity sections showed continuous moderate-resistivity features at this location. TH1 (fig. 16) also was in an area with moderate average resistivity. The top $4 \mathrm{~m}$ of the test hole contained sand and gravel, and the lower part consisted of well-sorted very fine and silty fine sand (table 3). TH19 (fig. 17) consisted of well-sorted, very fine and silty sand interbedded with sand and gravel (table 3 ). The $\mathrm{CC}$ resistivity section showed a moderately high-resistivity layer over a moderate-resistivity layer. The quality of DC data at TH19 and to the west was compromised by the breakdown of electrode connections in the water-borne resistivity cable, and the data were not used for interpretations.

The two layers seen in the selected CC resistivity sections near TH16A and TH19 cause the overall average resistivity to be moderate despite the higher-resistivity layer in the upper $4 \mathrm{~m}$. It should be noted that the majority of the $\mathrm{CC}$ resistivity data in this part of the Interstate Canal, which had moderate average resistivities, commonly showed a similar two-layer configuration, and canal leakage potential in this area may be higher than other sections of the canal with similar average resistivity values. 


\section{West of Lateral No. 2}

CC data collection on the Interstate Canal continued west of Lateral No. 2 for approximately $11 \mathrm{~km}$ into Goshen County, Wyoming. DC data were not collected west of Lateral No. 2, and no test holes were drilled in this area. This area of the canal showed a 2-km long moderate average resistivity section between two high average resistivity sections. The $\mathrm{CC}$ resistivity sections in the area with moderate average resistivities showed a single resistivity layer, in contrast to the two-layer configuration seen in the previous moderate average resistivity zone between Highway 79a and Lateral No. 2. The westernmost section of the study area displayed the highest average resistivity values for the Interstate Canal; therefore, this section also has the highest canal leakage potential (fig. 29).

\section{Tri-State Canal}

Both CC and DC resistivity sections were compared to lithologic descriptions (table 3). After an interpretive color scale was developed based on this analysis, the average resistivity of the $\mathrm{CC}$ resistivity data was used to develop interpretations of the comparative canal leakage potential for the majority of the canal, whereas sections that were flooded during CC data collection were filled in using the average resistivity from the DC resistivity survey (fig. 29).

The part of the Tri-State Canal between Sunflower Drain and Spottedtail Creek showed the highest canal leakage potential (fig. 29). East of this area, canal leakage potential was moderately high, with some areas of higher and lower leakage potential. West of Spottedtail Creek, canal leakage potential was generally moderate, although some small areas less than $1 \mathrm{~km}$ in length showed a high leakage potential. Some small areas of less than $2 \mathrm{~km}$ in length in the western part of the study area showed a low canal leakage potential.

\section{Durham Andrews Drain to Sunflower Drain}

The section of the Tri-State Canal between Durham Andrews Drain and Sunflower Drain showed a combination of high and moderate average resistivity values. TH5 (fig. 18) was in a section of high average resistivity and contained medium and coarse sand, as well as sand and gravel (table 3). High-resistivity features were seen in both the $\mathrm{CC}$ and DC resistivity sections near TH5.

TH17A (fig. 19), TH3 (fig. 20), and TH24 (fig. 21) were in areas with moderately high to high average resistivity. TH17A contained well-sorted fine sand and sand above $1.2 \mathrm{~m}$, and mostly sand and gravel in the remaining depth of investigation (table 3 ). The $\mathrm{CC}$ resistivity section at this location showed a thin, moderately high-resistivity layer at the surface and more resistive features below, whereas the DC resistivity section showed high-resistivity features below the influence of the water column. TH3 and TH24 contained moderately to well-sorted sand and silty sand with some coarser fragments (table 3). The CC resistivity section near TH3 showed highresistivity features throughout the majority of the depth of investigation, leading to a high average resistivity. Based on the lithologic description of TH3, a moderate average resistivity would have been expected based on the results from other test hole comparisons; however, the interpretive color scales could not be adjusted to make this location appear moderate without altering the interpretation throughout the majority of the canals. Therefore, the high average resistivity near TH3 is not representative of the sediments at this individual location. Moderately high-resistivity features were found in the $\mathrm{CC}$ resistivity section near TH24. Because sediments from TH24 were predominantly composed of moderately sorted sand with some coarser sand, the moderately high average resistivity was considered reasonable for TH24.

\section{Sunflower Drain to Spottedtail Creek}

The part of the canal between Sunflower Drain and Spottedtail Creek showed the highest continuous average resistivity features for the Tri-State Canal, and, therefore, the highest canal leakage potential (fig. 29). TH13 (fig. 22), TH14 (fig. 23), and TH21 (fig. 24) were in these high average resistivity features about $3 \mathrm{~km}$ west of Sunflower Drain. TH13 contained mostly moderately to well-sorted coarse sand with well-sorted fine sand occurring from $7 \mathrm{~m}$ to $8.5 \mathrm{~m}$. TH14 contained mixed sand and gravel interbedded with well-sorted fine sand with coarse sand occurring slightly below a depth of $8 \mathrm{~m}$. TH21 contained mixed sand and gravel (table 3). CC and DC resistivity sections for all three test holes were highly resistive, which is consistent with the interpretation of the lithologic logs.

Between the easternmost intersection of the Tri-State Canal with U.S. Highway 26 and Spottedtail Creek, water in the canal prevented collection of CC resistivity data. In this location, DC resistivity data were used to develop the canal leakage potential (fig. 29), which showed a continuation of the high average resistivity values and high canal leakage potential, whereas the 3-km stretch of canal downstream from Spottedtail Creek displayed some moderately high average resistivities, causing a small reduction in canal leakage potential.

\section{Spottedtail Creek to U.S. Highway 26}

The remaining part of the study area along the Tri-State Canal between Spottedtail Creek and the intersection with U.S. Highway 26 west of the town of Morrill displayed a wide variety of average-resistivity values, although the majority of the area was classified as moderate (fig. 29). Some small areas (less than $2 \mathrm{~km}$ in length) of low average resistivity were found; however, these values were typically not as low as areas on the Interstate Canal where the Brule Formation was found within the depth of investigation. Some small, isolated 
high average resistivity features were found in this part of the Tri-State Canal. Because of flooding water in the canal east of Akers Draw, a 2.5-km section of the canal leakage map was filled in using the DC resistivity data (fig. 29). TH23 (fig. 25) and TH8 (fig. 26) were both in moderate average resistivity areas and contained very fine and fine silty sand with some small layers of coarser sand in the lower one-third of the test holes (table 3). The CC and DC resistivity sections both showed moderate-resistivity features. TH 7 (fig. 27) was in a moderately high resistivity area and contained mixed sand to a depth of $1.8 \mathrm{~m}$, silt from 1.8 to $3.2 \mathrm{~m}$, and sand and coarse sand and gravel in the lower one-half of the depth of investigation (table 3 ). The $\mathrm{CC}$ and $\mathrm{DC}$ resistivity sections showed moderate-resistivity features above a depth of $2 \mathrm{~m}$, and both showed an increase in resistivity in the lower part of the depth of investigation.

\section{Assessment of Continuous Resistivity Profiling Techniques}

The CRP technique allows large quantities of resistivity data to be collected quickly in both terrestrial and under-water environments. Resistivity surveys were performed three times during 2004 to compare the effectiveness of DC and CC CRP techniques in characterizing near-surface lithology below the Interstate and Tri-State Canals. The water-borne DC CRP technique was used twice to represent different stages of the irrigation season as well as to assess the repeatability of the tool. Although the speed of data collection for both the $\mathrm{CC}$ and DC techniques is a great benefit when compared to traditional 2-D resistivity surveys, several difficulties were encountered during data collection and processing that were unique to large-scale CRP surveys.

\section{Effectiveness at Mapping Lithology}

Both CC and DC resistivity techniques were determined to be efficient at collecting shallow resistivity data over large areas. The depth of investigation for this study was controlled predominantly by the sinuosity of the canal system and not by the specific technique deployed, and the maximum depth of investigation for each tool was not assessed. Similar survey distances could be covered with each technique in any given day. The DC resistivity technique could be used over the entire length of the canal because of the water-borne nature of the system, whereas the $\mathrm{CC}$ resistivity technique was restricted to parts of the canal that were not flooded during the non-irrigation season.

Typically there was a high correlation between the CC and DC resistivity data, although there were some variations between the two techniques. For areas where high resistivity was measured using the DC resistivity technique, there consistently was a narrower range of resistivity than was measured using the $\mathrm{CC}$ resistivity technique. As water infiltrates the sediment below the canal, void spaces originally filled with air become filled with water, which could cause the resistivity of coarse-grained sediment, such as sand and gravel, to be reduced; therefore, less contrast would exist between saturated sand and gravel and the well-sorted finer-grained sediment. This also would account for the moderate-resistivity layer between 0 to $-2 \mathrm{~m}$ that is not usually seen in the $\mathrm{CC}$ resistivity sections (figs. 4-27). Another possible cause of the reduction in the range of resistivity is the influence of the water column itself on the inversion results. The measured apparent resistivity of the water column was typically 16 ohm-meters, which would be classified as a low-resistivity feature. Because about 30 percent of the DC resistivity section depth was occupied by the water column, this feature could have a substantial effect on the inversion process, and, therefore, on the calculated resistivity distribution.

When compared to the lithologic descriptions from the core samples, both CC and DC resistivity techniques were effective at differentiating between resistive and conductive sediments based on differences in relative grain size. Either technique could be used to develop a comparable interpretation of canal leakage potential (figs. 4-27).

In comparing the earlier and later sets of DC resistivity data, substantial changes were not observed in the co-located selected resistivity sections near test holes. Resistivity features detected at the beginning of the irrigation season in June and July were found in similar locations with similar depths and resistivity values during the August survey, when the canals had been delivering water for a minimum of 30 days (fig. 30). The DC CRP technique displayed excellent repeatability, and the duration of the irrigation season did not noticeably affect the resistivity of the subsurface. For example, there was no detectible reduction in resistivity in the high-resistivity feature seen between UTM Northings 4,657,100 $\mathrm{m}$ and 4,657,350 m in the Interstate Canal between June and August (fig. 30A). Similarly in the Tri-State Canal, there was no detectible change in resistivity values, and the same moderate-resistivity "valley" was found during both surveys centered near UTM Easting 608,650 m (fig. 30B). It is likely that most of the coarse-grained sediment became fully saturated early in the irrigation season before the first DC resistivity survey began, which could explain the similar resistivity values.

\section{Technical Obstacles to Continuous Resistivity Profiling}

Several difficulties were encountered during the deployment of the water-borne resistivity cable during DC data collection. Weakness in the construction of the cable led to the eventual breakdown of the electrode connections during the initial DC resistivity survey in June 2004. After repair of the cable, the addition of an external support rope reduced additional breakdown during the following two surveys. This external rope was not an ideal solution, as it frequently 
snagged floating debris, increased drag on the cable, and easily became tangled. The addition of an internal support member that is not part of the electrical connection would eliminate the need for external support and reduce the associated difficulties.

For the inversion of the water-borne DC resistivity data, RES2DINV has a specific option that allows the water column to be constrained using a constant, user-assigned apparent resistivity value for all data occurring above the bed of the canal. However, for high-resistivity parts of the canals, it was found that this technique did not provide the lowest RMS difference and frequently caused instabilities in the inversion model, with developed calculated resistivity values exceeding 100,000 ohm-m. These problems were most likely caused by the thickness of the water column, which represented more than one-third of the total depth of investigation in some locations. By forcing this part of the resistivity section to a low resistivity value of $16 \mathrm{ohm}-\mathrm{m}$, small increases in the apparent resistivity values below the canal bed were interpreted as very large increases in the calculated resistivity, leading to unreasonable resistivity values and instability (M.H. Loke, Geotomo Software, written commun., November 2004). Substantially improved results were achieved without the water column constraint. Also, the 3-m current electrode separation was not adequate for areas of the canals where water depth exceeded $3 \mathrm{~m}$, and the penetration of current into the subsurface was not optimal, resulting in smaller potential differences and a lower signal-to-noise ratio. By increasing the current electrode spacing to a distance that always exceeds the thickness of the water column and by selecting an array with higher signal strength than the dipole-dipole, the total depth of investigation and signal-to-noise ratio could both be increased, possibly alleviating both of these problems.

Interpreting individual inverted resistivity sections with unique local coordinate systems is cumbersome for large-scale surveys, particularly for comparing co-located resistivity data. Because of the 2-D limitation of most inversion programs, georeferenced coordinates, such as the latitude and longitude coordinates collected during the resistivity surveys, cannot be used as locational information during the inversion process. However, because of the inability of inversion software to use these coordinates or carry them through the inversion process, a lengthy procedure was necessary to reunite the inverted resistivity data with the georeferenced coordinates. As the inverted resistivity section represents a possible "true" resistivity of the subsurface, it is the most useful result of the resistivity survey for making reasonable interpretations about the properties of the subsurface. Dramatic improvements in the efficiency and quality of interpreting inverted resistivity sections were made by looking at the data in a geospatial analysis environment. Advancements in inversion software to allow coordinates to be carried through the inversion procedure would alleviate the need for repetitive, time-consuming georeferencing procedures. If these advancements could be made, it would be necessary for the georeferenced location associated with each point in the raw data file to correspond to the apparent resistivity measurement location, not the position of the GPS antenna when the apparent resistivity measurement was made. In the case of this study, the GPS antenna was at the location of the boat or ATV, possibly more than $25 \mathrm{~m}$ from the actual measurement position. The development of an algorithm that adjusts coordinates to accurately reflect this offset would allow the correct location of the apparent resistivity value to be carried through the process.

\section{Summary}

A ground-water-flow model is being developed in the North Platte River Valley to evaluate the effects of using leakage of water from selected irrigation canal systems to manage ground-water recharge. For the ground-water-flow model to accurately simulate current or predict future ground-water and surface-water conditions in the North Platte River Valley, input of specific variables, such as canal leakage, is imperative.

However, canal leakage in a model often is estimated based on lithologic data that are collected from boreholes that can be kilometers apart and not in the proximity of the canals. Therefore, canal leakage estimates based on data collected from distant sites may not be representative of actual conditions, and errors in the ground-water-flow model can be caused by incorrect estimates.

The U.S. Geological Survey, in cooperation with the North Platte Natural Resources District, used capacitively coupled (CC) and direct-current (DC) continuous resistivity profiling techniques to map near-surface lithologies of parts of the Interstate and Tri-State Canals in the spring and summer of 2004. Test holes were then drilled in the fall of 2004 at several locations in both canals to verify the results of the resistivity surveys, to provide a benchmark for determining the effectiveness of each technique, and to develop an interpretive scale that was used to represent the relative canal leakage potential.

Both CC and DC resistivity data were collected, processed, inverted, and georeferenced to create a three-dimensional database containing results for each technique for both the Interstate and Tri-State Canals. This facilitated the consistent interpretation of resistivity data, in which resistivity sections near test holes were simultaneously compared to lithologic information, and a single interpretive color scale was developed for each resistivity technique. This scale was then applied to resistivity data where test holes did not exist, creating a uniform interpretation for the entire study area.

A vertically averaged resistivity value for each geographic location where data exist was calculated, resulting in a single resistivity value that was used to represent the overall resistivity at that location. The interpretive color scale developed from the comparison of resistivity data to lithologic logs was then applied to this single resistivity value, and this was then evaluated against the lithologic information and determined to accurately represent the data. The average resistivity was then used to interpret the relative canal leakage potential. 
The highest canal leakage potential in the Interstate Canal occurred west of the Wyoming-Nebraska State line. Moderately high to moderate canal leakage potential occurred between Lateral No. 14 and Lateral No. 8, as well as between Highway 79a and Lateral No. 2. Between Dry Spottedtail Creek and Lateral No. 14, a wide variety of leakage potentials were found, including high leakage potential where the canal crossed alluvial channels, moderate leakage potential values from Dry Spottedtail Creek and extending $3 \mathrm{~km}$ directly southwest, and low leakage potentials in areas of Brule Formation outcrops. Low canal leakage potential was found between Highway 71 and Spottedtail Creek, as well as between Lateral No. 8 and about $600 \mathrm{~m}$ west of Highway 79a. The Brule Formation was found within the depth of investigation in both of these areas.
The highest canal leakage potential in the Tri-State Canal was between Sunflower Drain and Spottedtail Creek. East of this area, canal leakage potential was moderately high, although some areas of higher and lower potential were found in this section. West of Spottedtail Creek, canal leakage potential was generally moderate, although some small areas less than $1 \mathrm{~km}$ in length had a high leakage potential. Some small areas less than $2 \mathrm{~km}$ in length west of Spottedtail Creek had a moderate to low canal leakage potential.

Both CC and DC continuous resistivity profiling techniques, when compared to the lithologic descriptions, were determined to be effective at differentiating coarse-grained sediment from fine-grained sediment. Results from both techniques could be interpreted to develop similar spatial distributions of canal leakage potential, although different interpretive scales were developed for each technique because of the different ranges of resistivity values.

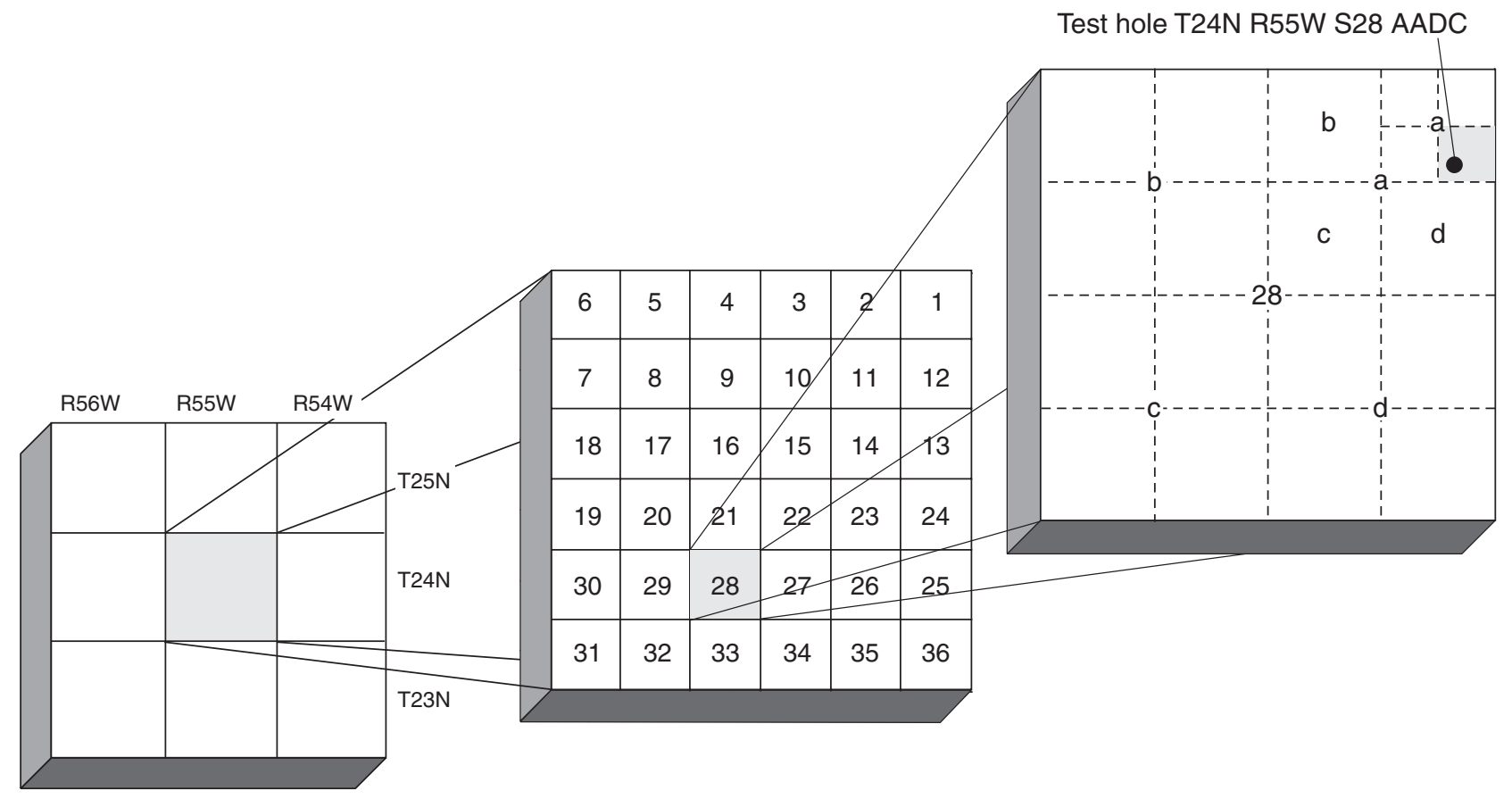

Figure 28. Legal land-description numbering system for test holes listed in table 3. 
Table 3. Lithologic descriptions for test holes.

$[\mathrm{TH}$, test hole; \%, percent; >, greater than; <, less than; T24N R55W S28 AADC, legal description (see fig. 28 for diagram of legal-description numbering system)]

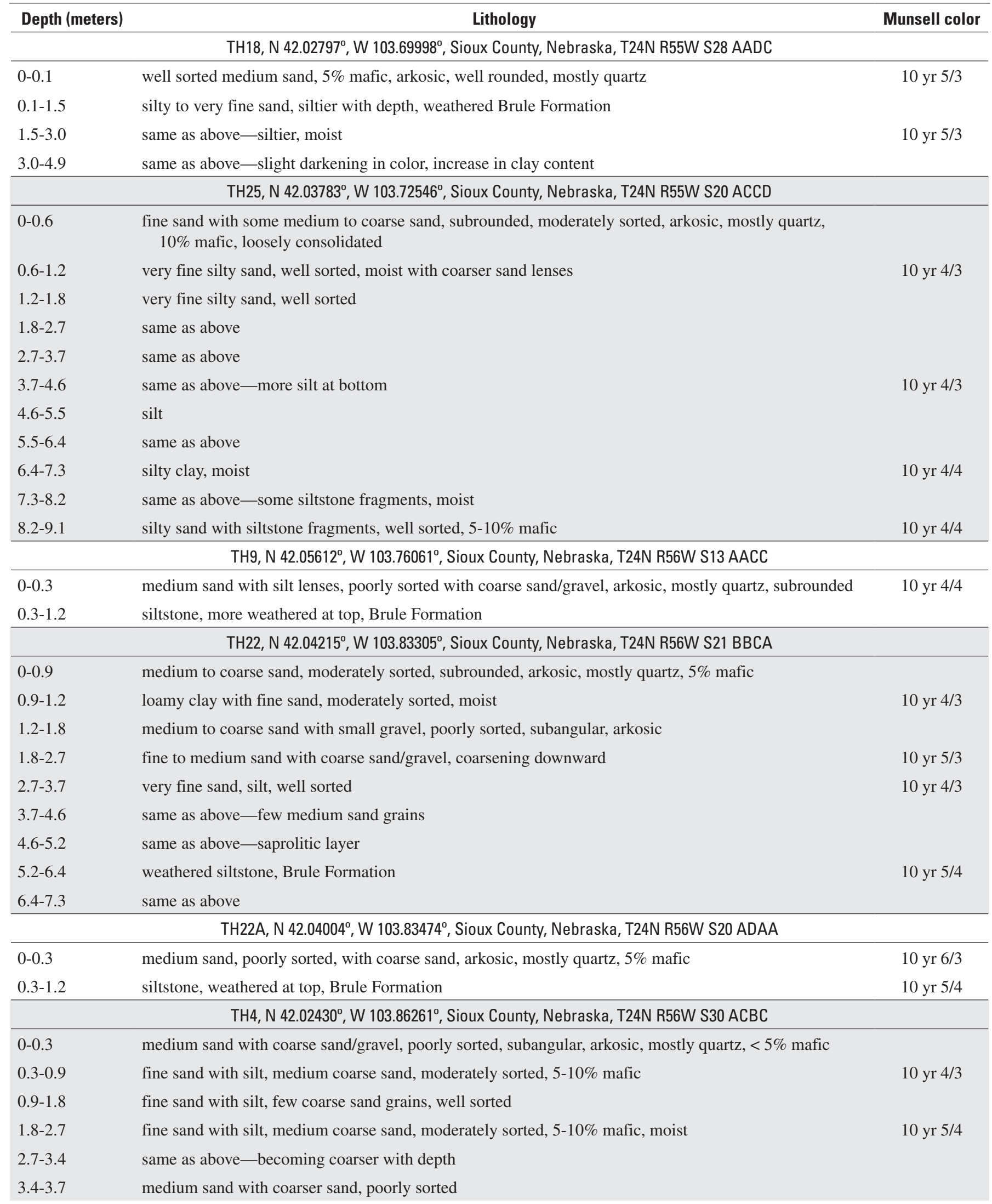


Table 3. Lithologic descriptions for test holes.-Continued

\begin{tabular}{ll}
\hline Depth (meters) & \multicolumn{1}{c}{ Lithology } \\
\hline & \multicolumn{1}{c}{ TH4, N 42.02430 ${ }^{\circ}$, W $103.86261^{\circ}$, Sioux County, Nebraska, T24N R56W S30 ACBC-Continued } \\
\hline $3.7-4.3$ & medium sand with coarse sand/gravel, poorly sorted, subangular, arkosic, becoming finer with depth \\
$4.3-4.6$ & fine/medium sand, well sorted arkosic, 5\% mafic \\
$4.6-5.5$ & fine/medium sand, well sorted subrounded, arkosic, 5\% mafic, coarsening downward, well packed \\
$5.5-6.1$ & fine sand, moderately well sorted, arkosic, 5\% mafic, coarse sand/gravel \\
$6.1-6.4$ & medium sand with coarse sand/gravel, subangular, poorly sorted, arkosic, mostly quartz, <5\% mafic \\
$6.4-7.0$ & loose fine sand with coarse sand/gravel, very poorly sorted, subangular \\
$7.0-7.6$ & same as above \\
$7.6-8.2$ & same as above-more consolidated \\
$8.2-8.8$ & same as above \\
\hline
\end{tabular}

TH20A, N 42.03291', W 103.89057 , Sioux County, Nebraska, T24N R57W S24 CBDC

0-1.2 fine sand with coarse sand/gravel, moderately sorted, arkosic, $10 \%$ mafic, subrounded $10 \mathrm{yr} 4 / 3$

1.2-1.8 same as above-slightly darker

1.8-2.7 same as above-clay lenses

10 yr $6 / 3$

2.7-3.7 medium sand with coarse sand, moderately sorted, arkosic, 5\% mafic, subangular, fining downward, saprolitic siltstone lense

3.7-4.6 same as above-10-15\% mafic

4.6-4.8 silt and fine sand, siltstone, Brule Formation

$10 \mathrm{yr} 6 / 4$

4.8-5.1 silt and fine sand, siltstone, Brule Formation

\begin{tabular}{|c|c|c|}
\hline \multicolumn{3}{|c|}{ TH26, N 42.05470', W 103.94499, Sioux County, Nebraska, T24N R57W S16 BDBA } \\
\hline $0-0.3$ & medium sand, poorly sorted, subrounded, arkosic, $10 \%$ mafic & $10 \mathrm{yr} 5 / 3$ \\
\hline $0.3-1.2$ & very fine sand, moderately sorted, subrounded, arkosic, up to $20 \%$ mafic, some coarse sand & $10 \mathrm{yr} 4 / 3$ \\
\hline $1.2-1.8$ & same as above-with more coarse sand lenses & \\
\hline $1.8-2.7$ & very fine sand, well sorted, subrounded, arkosic, up to $20 \%$ mafic & $10 \mathrm{yr} 5 / 3$ \\
\hline 2.7-3.7 & very fine sand, subrounded, arkosic, $10-15 \%$ mafic, moderately sorted, some coarse sand, some silt & \\
\hline $3.7-4.6$ & same as above & \\
\hline 4.6-5.5 & same as above & \\
\hline $5.5-6.4$ & same as above & \\
\hline $6.4-7.3$ & same as above & $10 \mathrm{yr} 5 / 4$ \\
\hline 7.3-8.2 & same as above-more silt & \\
\hline $8.2-9.1$ & same as above & 10 yr $5 / 3$ \\
\hline
\end{tabular}

coarse to medium sand, poorly sorted, subangular, 5-10\% mafic, arkosic-fill

0.3-1.2 very fine sand with coarse sand, 5-10\% mafic, arkosic, moderately sorted fine sand with $25 \%$ coarse sand/gravel, subangular, poorly sorted

1.8-2.7 same as above-less coarse sand/gravel-siltstone lense

2.7-3.7 same as above

$3.7-4.6$

same as above-coarse sand/gravel

medium sand with coarse sand/gravel, poorly sorted, subrounded, arkosic, up to $20 \%$ mafic, mostly quartz

5.5-5.8 coarse sand with some gravel, poorly sorted, subrounded, arkosic, mostly quartz 
Table 3. Lithologic descriptions for test holes.-Continued

\begin{tabular}{|c|c|c|}
\hline Depth (meters) & Lithology & Munsell color \\
\hline \multicolumn{3}{|c|}{ TH0, N 42.06280 ${ }^{\circ}$, W $103.96209^{\circ}$, Sioux County, Nebraska, T24N R57W S8 CADD—Continued } \\
\hline $7.0-7.6$ & same as above-more coarse sand/gravel & \\
\hline $8.2-8.8$ & coarse sand, well sorted, subangular, mostly quartz & \\
\hline $8.8-9.1$ & same as above & \\
\hline \multicolumn{3}{|c|}{ TH15, N 42.06912, W 103.97354', Sioux County, Nebraska, T24N R57W S7 ADBD } \\
\hline $0-0.3$ & medium grained sand with some coarse sand, subrounded, $5 \%$ mafic arkosic, mostly quartz & $10 \mathrm{yr} 5 / 3$ \\
\hline $0.3-1.2$ & $\begin{array}{l}\text { very fine sand to loamy sand, well sorted, some coarse sand, }<5 \% \text { gravel, slight increase in clay content } \\
\text { towards bottom }\end{array}$ & $10 \mathrm{yr} 4 / 3$ \\
\hline $1.2-1.8$ & same as above & \\
\hline $3.0-3.4$ & coarse to very coarse gravel with some sand, arkosic, very poorly sorted & $10 \mathrm{yr} 4 / 3$ \\
\hline $3.4-3.7$ & very fine sand, very well sorted & $10 \mathrm{yr} 5 / 4$ \\
\hline $3.7-4.6$ & same as above-with some silt, coarser sand & \\
\hline $4.6-5.5$ & same as above & \\
\hline $5.5-6.7$ & same as above—coarser material near top, darker color & $10 \mathrm{yr} 4 / 3$ \\
\hline $6.7-7.0$ & fine sand, poorly sorted, some coarse sand to fine gravel, lightening in color & \\
\hline $7.0-7.6$ & very fine sand, well sorted, moist & $10 \mathrm{yr} 4 / 3$ \\
\hline $7.6-8.2$ & same as above & \\
\hline $8.2-8.8$ & same as above-up to $20 \%$ mafic & \\
\hline 2.4-3.0 & same as above & \\
\hline $3.0-3.4$ & same as above-less sand & $10 \mathrm{yr} 5 / 3$ \\
\hline \multicolumn{3}{|c|}{ TH16A, N42.14680 ${ }^{\circ}$, W 104.05243', Sioux County, Nebraska, T25N R58W S12 CCBC } \\
\hline $0-0.6$ & coarse sand with gravel, subrounded, poorly sorted, arkosic, mostly quartz, 5-10\% mafic & 10 yr $5 / 3$ \\
\hline $0.6-1.2$ & fine sand with coarse sand/gravel, moderately sorted, subrounded, arkosic & 10 yr $4 / 3$ \\
\hline $1.2-2.7$ & same as above-more coarse sand/gravel & \\
\hline $2.7-3.2$ & silty fine sand with weathered siltstone fragments & $10 \mathrm{yr} 5 / 6$ \\
\hline $3.2-3.4$ & siltstone, Brule Formation & \\
\hline
\end{tabular}

TH11A, N 42.12312 ${ }^{\circ}$, W 104.05290 ${ }^{\circ}$, Goshen County, Wyoming T25N R60W S22 DADA

0-1.2 sandy loam, well sorted, $10 \%$ mafic

$10 \mathrm{yr} 4 / 3$

1.2-1.8 same as above-few coarse sand/gravel, more sand at bottom

1.8-2.7 silt, well sorted, $10 \%$ mafic

2.7-3.7 same as above-some coarse sand/gravel

10 yr $5 / 4$

3.7-4.6 same as above

4.6-5.5 coarse sand, poorly sorted, subrounded, gravel, arkosic, mostly quartz, $5 \%$ mafic

$10 \mathrm{yr} 5 / 3$

5.5-5.8 same as above 
Table 3. Lithologic descriptions for test holes.-Continued

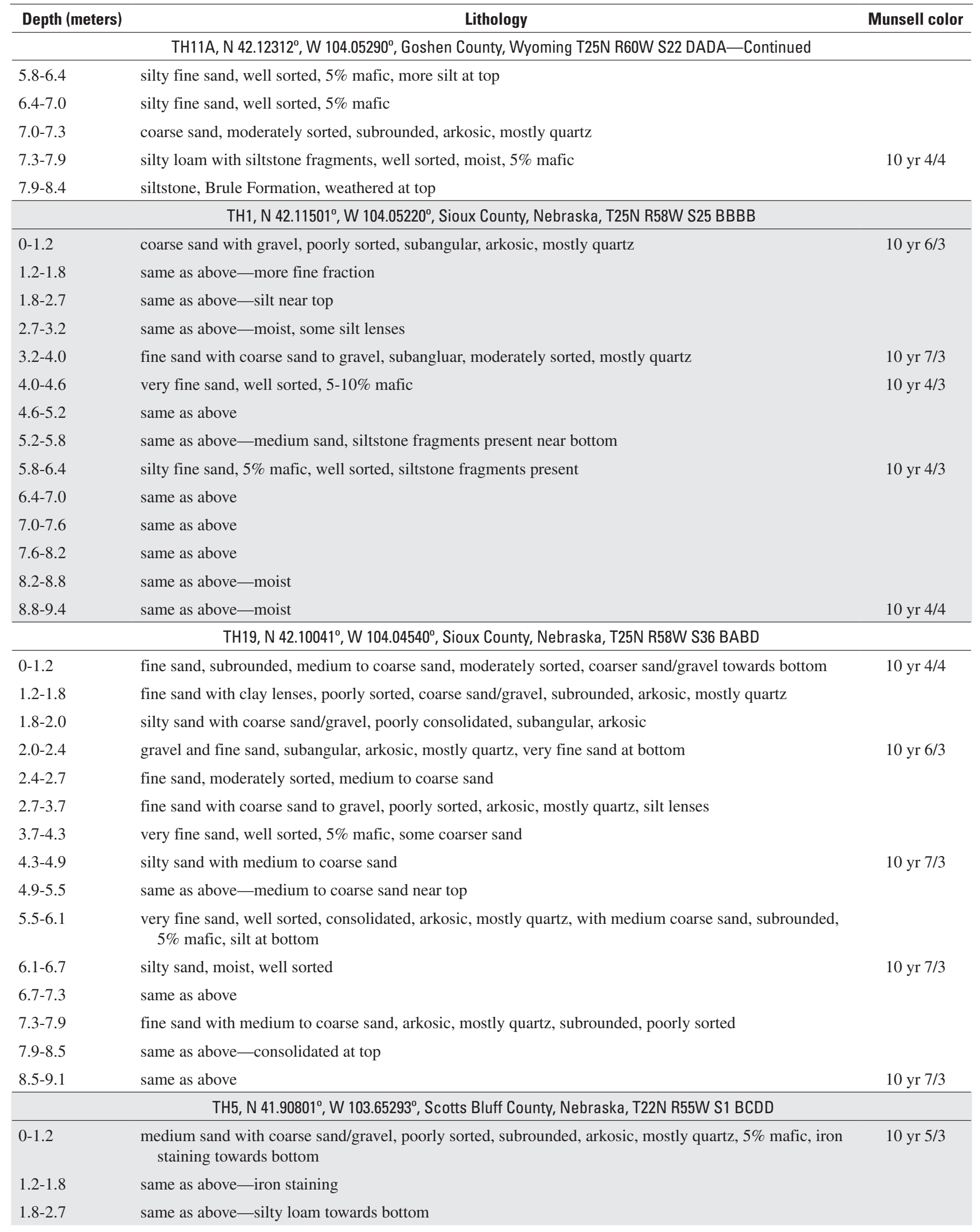


Table 3. Lithologic descriptions for test holes.-Continued

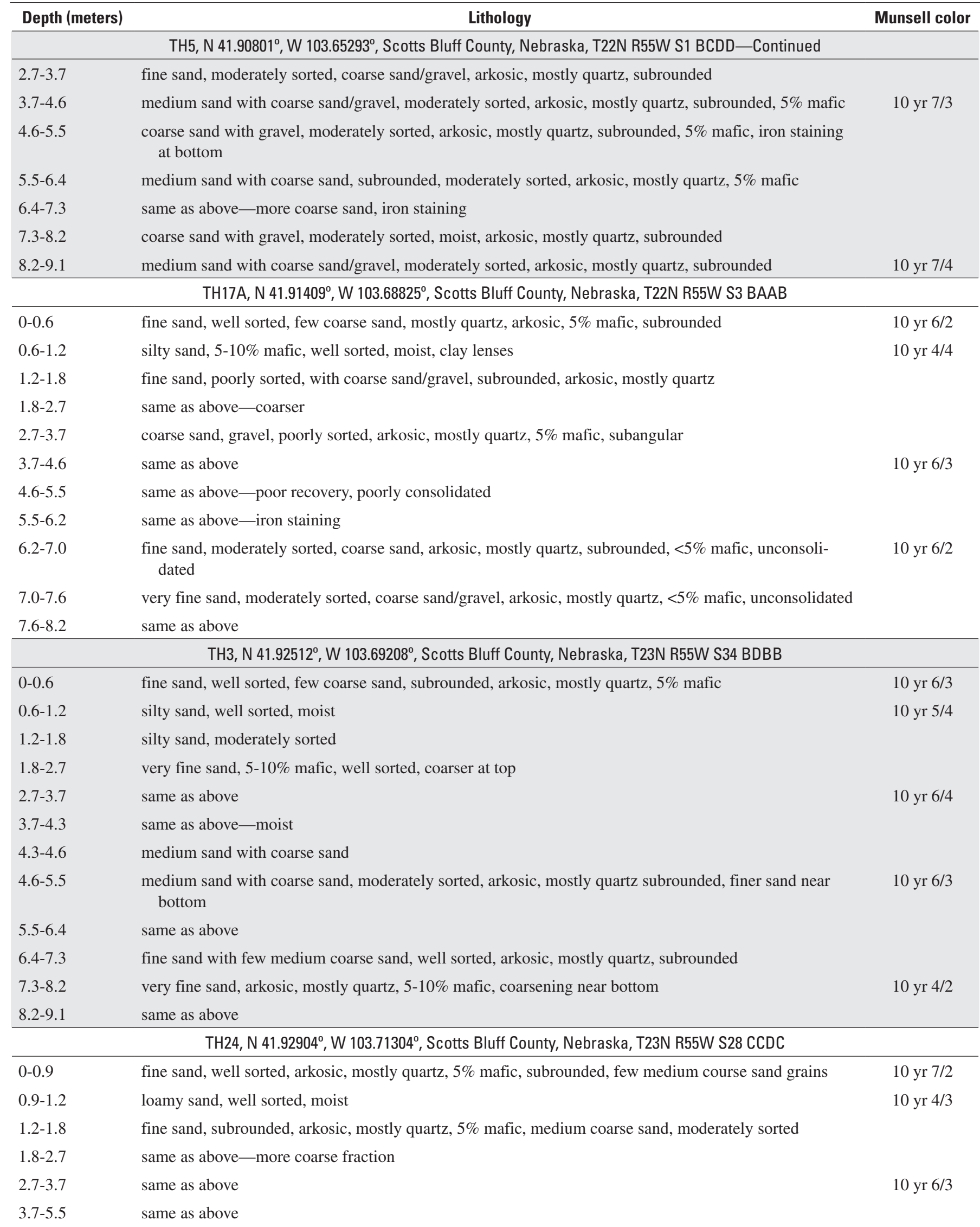


Table 3. Lithologic descriptions for test holes.-Continued

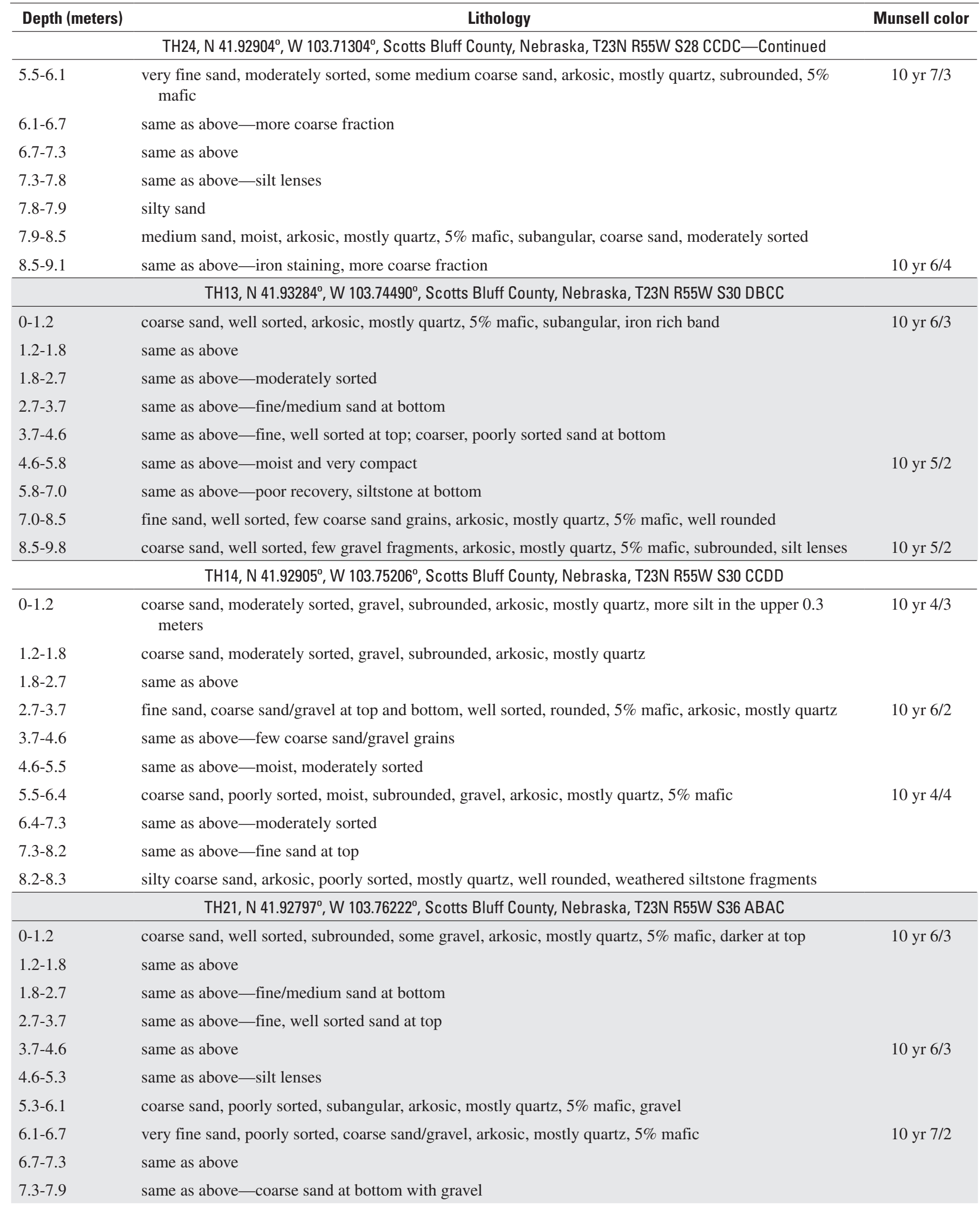


Table 3. Lithologic descriptions for test holes.-Continued

\begin{tabular}{|c|c|c|}
\hline Depth (meters) & Lithology & Munsell color \\
\hline \multicolumn{3}{|c|}{ TH21, N 41.92797 ${ }^{\circ}$ W $103.76222^{\circ}$, Scotts Bluff County, Nebraska, T23N R55W S36 ABAC-Continued } \\
\hline 7.9-8.5 & coarse sand, poorly sorted, subrounded, gravel, arkosic, mostly quartz, $5 \%$ mafic & \\
\hline $0-0.6$ & coarse sand, well rounded, well sorted, gravel, arkosic, mostly quartz, $<5 \%$ mafic & $10 \mathrm{yr} 6 / 2$ \\
\hline $0.6-1.2$ & silty, fine sand, well sorted, few coarse sand grains, $5 \%$ mafic & $10 \mathrm{yr} 4 / 4$ \\
\hline $1.8-2.7$ & silty loam, well sorted & \\
\hline $2.7-3.7$ & silty fine sand, well sorted, few coarse sand grains, $5 \%$ mafic & \\
\hline $3.7-4.6$ & silt, well sorted, moist & $10 \mathrm{yr} 4 / 3$ \\
\hline 4.6-5.5 & $\begin{array}{l}\text { silty fine sand, moderately sorted, few medium coarse sand grains, } 5 \% \text { mafic, coarser at bottom, liquid/ } \\
\text { saturated }\end{array}$ & \\
\hline 7.3-8.2 & fine silty sand, well sorted, arkosic, poor recovery, silty water/saturated & \\
\hline $8.2-9.1$ & same as above-silty water/saturated & \\
\hline \multicolumn{3}{|c|}{ TH8, N $41.96270^{\circ}$, W $103.83604^{\circ}$, Scotts Bluff County, Nebraska, T23N R56W S17 DABD } \\
\hline $0-0.6$ & fine sand, well sorted, rounded, arkosic, mostly quartz, $5 \%$ mafic, few coarse sand grains & 10 yr $6 / 3$ \\
\hline $0.6-1.2$ & very fine silty sand, well sorted moist & $10 \mathrm{yr} 4 / 3$ \\
\hline $1.2-1.5$ & same as above—-becoming fine dry sand, arkosic, rounded, mostly quartz & \\
\hline $1.5-1.8$ & silt, well sorted & \\
\hline $1.8-2.7$ & same as above-darker at top & $10 \mathrm{yr} 4 / 4$ \\
\hline $2.7-3.7$ & same as above & \\
\hline 7.6-8.2 & coarse sand, poorly sorted, arkosic, quartz, $5 \%$ mafic, subrounded & \\
\hline $8.2-9.1$ & silty fine sand-well sorted, some coarse sand, $5 \%$ mafic, moist, lense of coarse sand at 8.8 meters & $10 \mathrm{yr} 4 / 3$ \\
\hline \multicolumn{3}{|c|}{ 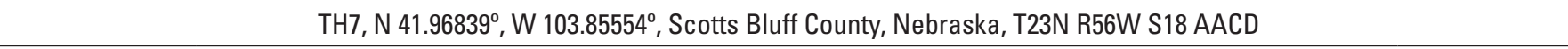 } \\
\hline $0-0.6$ & medium sand, well sorted, arkosic, mostly quartz, $5 \%$ mafic, rounded & 10 yr $6 / 3$ \\
\hline $0.6-1.2$ & fine silty sand, coarse sand, medium sorted & $10 \mathrm{yr} 4 / 3$ \\
\hline $1.2-1.4$ & same as above & \\
\hline $1.4-1.7$ & coarse sand, poorly sorted, arkosic, subangular & \\
\hline $1.7-1.8$ & fine silty sand, coarse sand, moderately sorted & \\
\hline $1.8-3.2$ & silt, well sorted & \\
\hline $3.2-3.7$ & medium sand, poorly sorted, coarse sand, arkosic, $5 \%$ mafic, subangular & \\
\hline $3.7-4.6$ & coarse sand, moderately sorted with gravel, arkosic, mostly quartz, subrounded, $5 \%$ mafic & \\
\hline $4.6-5.5$ & same as above & 10 yr $5 / 3$ \\
\hline $5.5-6.4$ & same as above & \\
\hline $6.4-7.3$ & same as above-more medium/fine sand & \\
\hline $7.3-8.2$ & same as above-fine, well sorted sand at bottom & \\
\hline $8.2-9.1$ & medium sand, well sorted, arkosic, mostly quartz, subrounded, $5 \%$ mafic, some gravel & \\
\hline
\end{tabular}




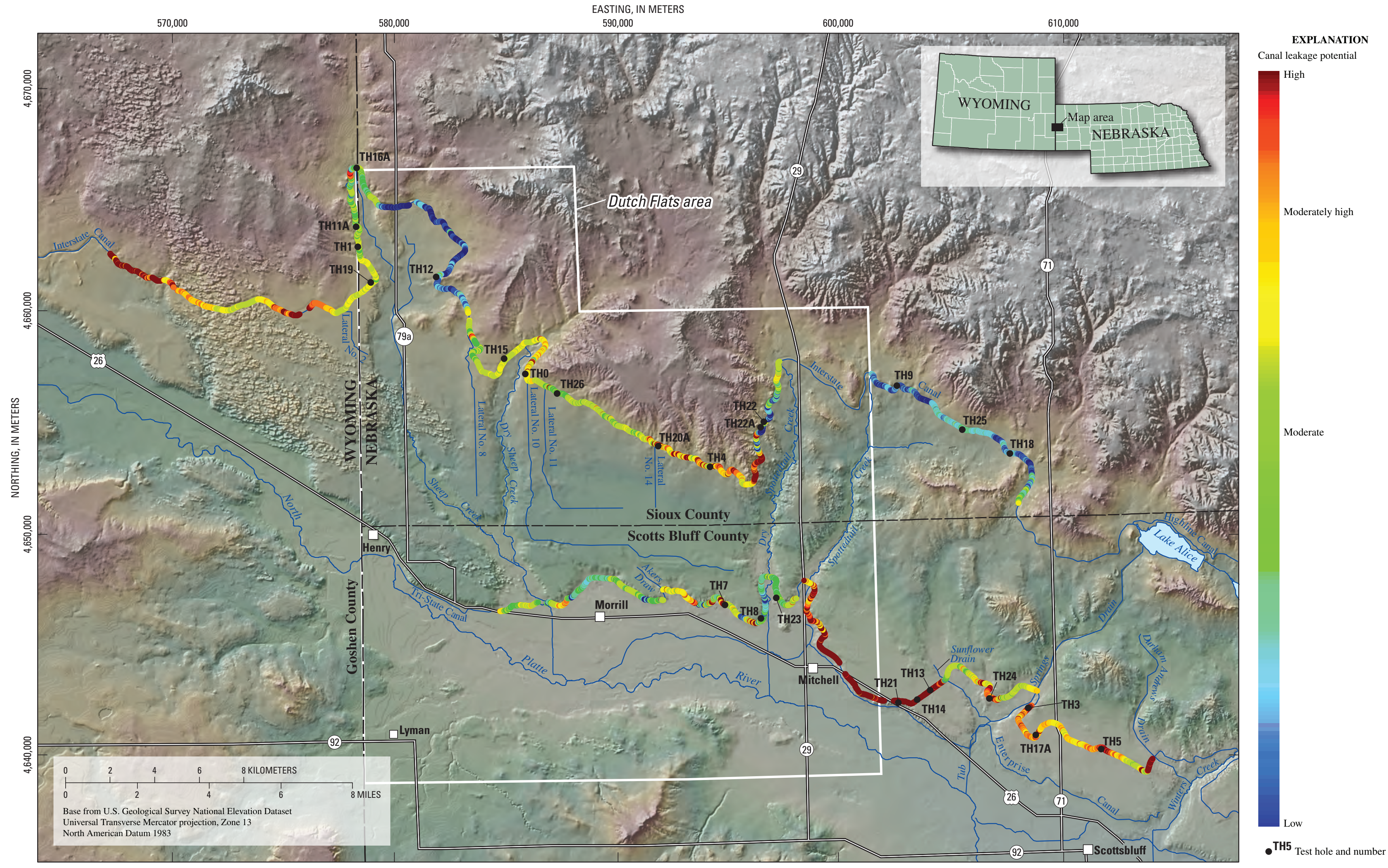

Figure 29. Potential for canal leakage from the Interstate and Tri-State Canals based on results from capacitively coupled and direct-current resistivity surveys. 

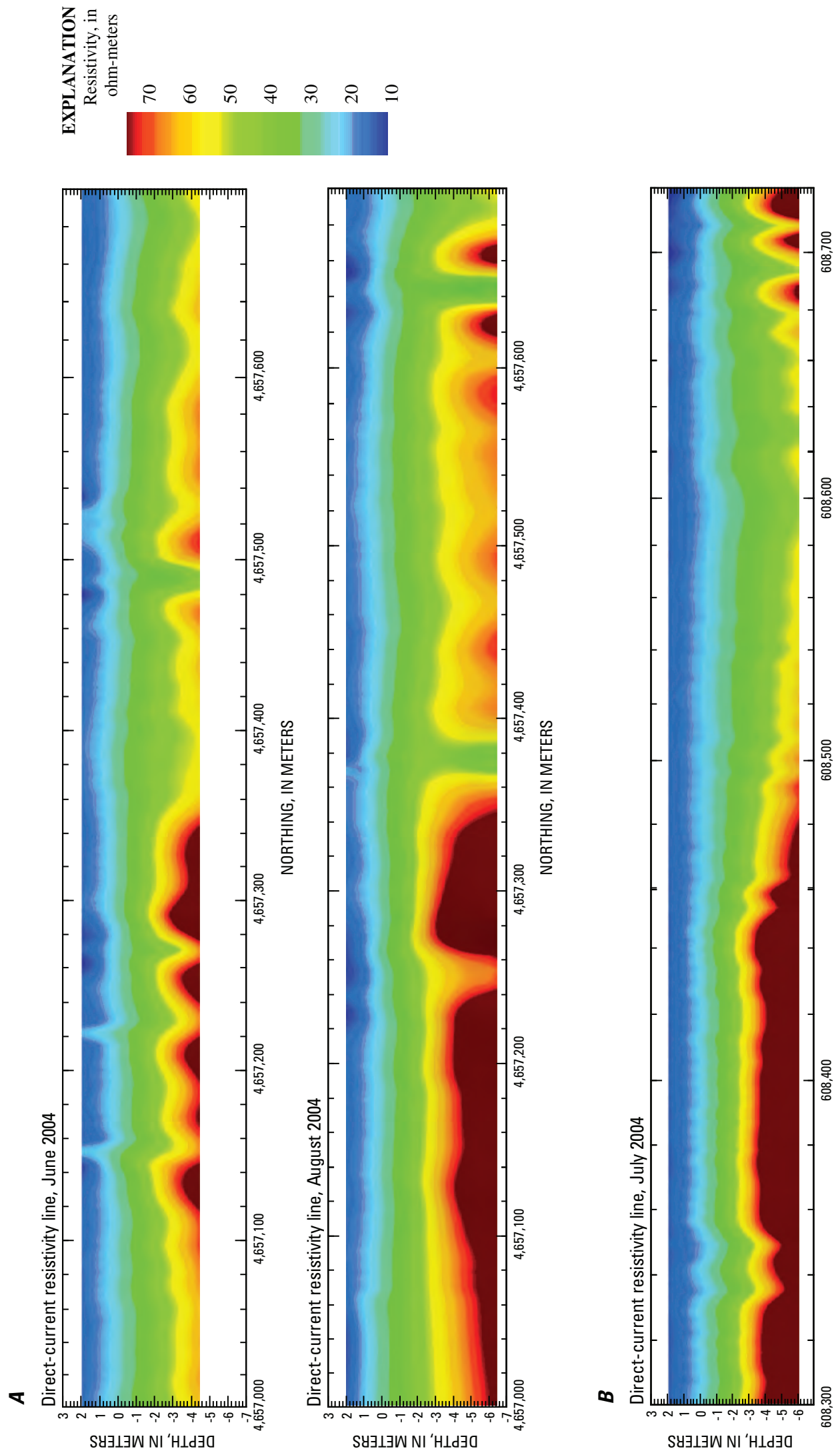

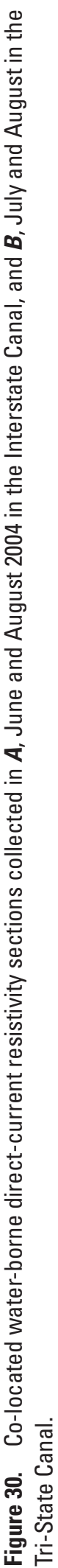




\section{Cited References}

Babcock, H.M., and Visher, F.N., 1951, Ground-water conditions in the Dutch Flats area, Scotts Bluff and Sioux Counties, Nebraska, with a section on Chemical quality of the ground water, by W.H. Duram: U.S. Geological Survey Circular 126, $51 \mathrm{p}$.

Darton, N.H., 1903a, Geologic atlas of the United States, Scotts Bluff folio, Nebraska: U.S. Geological Survey Folio 88,5 p.

Darton, N.H., 1903b, Preliminary report on the geology and water resources of Nebraska west of the one hundred and third meridian: U.S. Geological Survey Professional Paper 17, 69 p., 43 pls.

Dreeszen, V.H., Sibray, S.S., and Smith, F.A., 2002, Scotts Bluff County test-hole logs: Nebraska Water Survey TestHole Report No. 79, Conservation and Survey Division, University of Nebraska-Lincoln, 280 p.

Driscoll, F.D., 1986, Groundwater and wells: St. Paul, Minnesota, Johnson Division, 1089 p.

Freeze, R.A., and Cherry, J.A., 1979, Groundwater: Englewood, New Jersey, Prentice Hall, 604 p.

Geometrics, 2004, MagMap2000 version 4.56: San Jose, California, accessed March 2004 at http://www.geometrics. com/Downloads/MagDnForm/MagDown/magdown.html

Grant, F.S., and West, G.F., 1965, Interpretation theory in applied geophysics-Part 3, electrical conduction and electromagnetic induction methods: New York, New York, McGraw-Hill Book Company, p. 384-572.

IRIS Instruments, 2003, Prosys version 09.05.00: Orleans, France, accessed November 2004 at http://www.irisinstruments.com/

Keller, G.V., and Frischknecht, F.C., 1966, Electrical methods in geophysical prospecting: Oxford, United Kingdom, Pergamon Press Inc., 519 p.

Loke, M.H., 2000, Electrical imaging surveys for environmental and engineering studies - a practical guide to 2-D and 3-D surveys: M.H. Loke, 62 p., accessed August 2002 at http://www.abem.com/files/res/2Dnotes.pdf

Loke, M.H., 2004, RES2DINV version 3.54-Rapid 2D resistivity and IP inversion using the least-squares methodGeoelectrical Imaging 2-D and 3-D: Penang, Malaysia, Geotomo Software, 130 p., accessed September 12, 2005, at http://www.geoelectrical.com/download.html
Merry, A.G., Martin, P.J., and Sussman, J., 2003, Importance of local geologic structure in a regional groundwater flow and contaminant transport model for Lansing, Michigan, in Poeter, Eileen, Zheng, Chunmiao, Hill, Mary, and Doherty, John, MODFLOW and more 2003-Understanding through Modeling Conference, v. \#II, September 16, 2003, Denver, Colorado, [Proceedings], p. 655-660.

North Platte Natural Resources District, 2004, NPNRD's Integrated Management Plan: Gering, Nebraska, accessed August 2005 at http://www.npnrd.org/LB962.htm

Souders, V.L., 1986, Geologic sections, ground-water maps, and logs of test holes, Morrill County, Nebraska: Lincoln, Nebraska, Conservation and Survey Division, University of Nebraska-Lincoln, Open-File Report, 90 p.

Swinehart, J.B., Souders, V.L., DeGraw, H.M., Diffendal, R.F., Jr, 1985, Cenozoic paleogeography of western Nebraska, in Flores, R.M. and Kaplan, S.S., eds., Rocky Mountain Section-Society for Sedimentary Geology (S.E.P.M.), Conference on Cenozoic Paleography of West-Central United States, 1985, Denver, Colorado, p. 209-229.

Verstraeten, I.M., Sibray, S.S., Cannia, J.C., and Tanner, D.Q., 1995, Reconnaissance of ground-water quality in the North Platte Natural Resources District, western Nebraska, June-July 1991: U.S. Geological Survey Water-Resources Investigations Report 94-4057, 114 p.

Verstraeten, I.M., Steele, G.V., Cannia, J.C., Hitch, D.E., Scripter, K.G., Böhlke, J.K., Kraemer, T.F., and Stanton, J.S., 2001, Interaction of surface water and ground water in the Dutch Flats area, western Nebraska, 1995-99: U.S. Geological Survey Water-Resources Investigations Report 01-4070, 56 p.

Wenzel, L.K., Cady, R.C., and Waite, H.A., 1946, Geology and ground-water resources of Scotts Bluff County, Nebraska: U.S. Geological Survey Water-Supply Paper 943, $150 \mathrm{p}$.

Zohdy, A.A.R, Eaton, G.P., and Mabey, D.R., 1974, Application of surface geophysics to ground-water investigations: U.S. Geological Survey Techniques of Water-Resources Investigations Book 2, Chap. D1, 116 . 



\section{Supplemental Data Section}

Figures 4-27. Comparisons of lithologic data to inverted capacitively coupled and direct-current resistivity sections and average resistivity curves. Because of the sinuosity of the canals, some distortion of the inverted resistivity sections may occur when displayed in a two-dimensional environment. Test holes have been plotted with respect to their relation to the inverted resistivity sections and not the displayed geographic coordinate. 
$\boldsymbol{A}$

$\boldsymbol{B}$
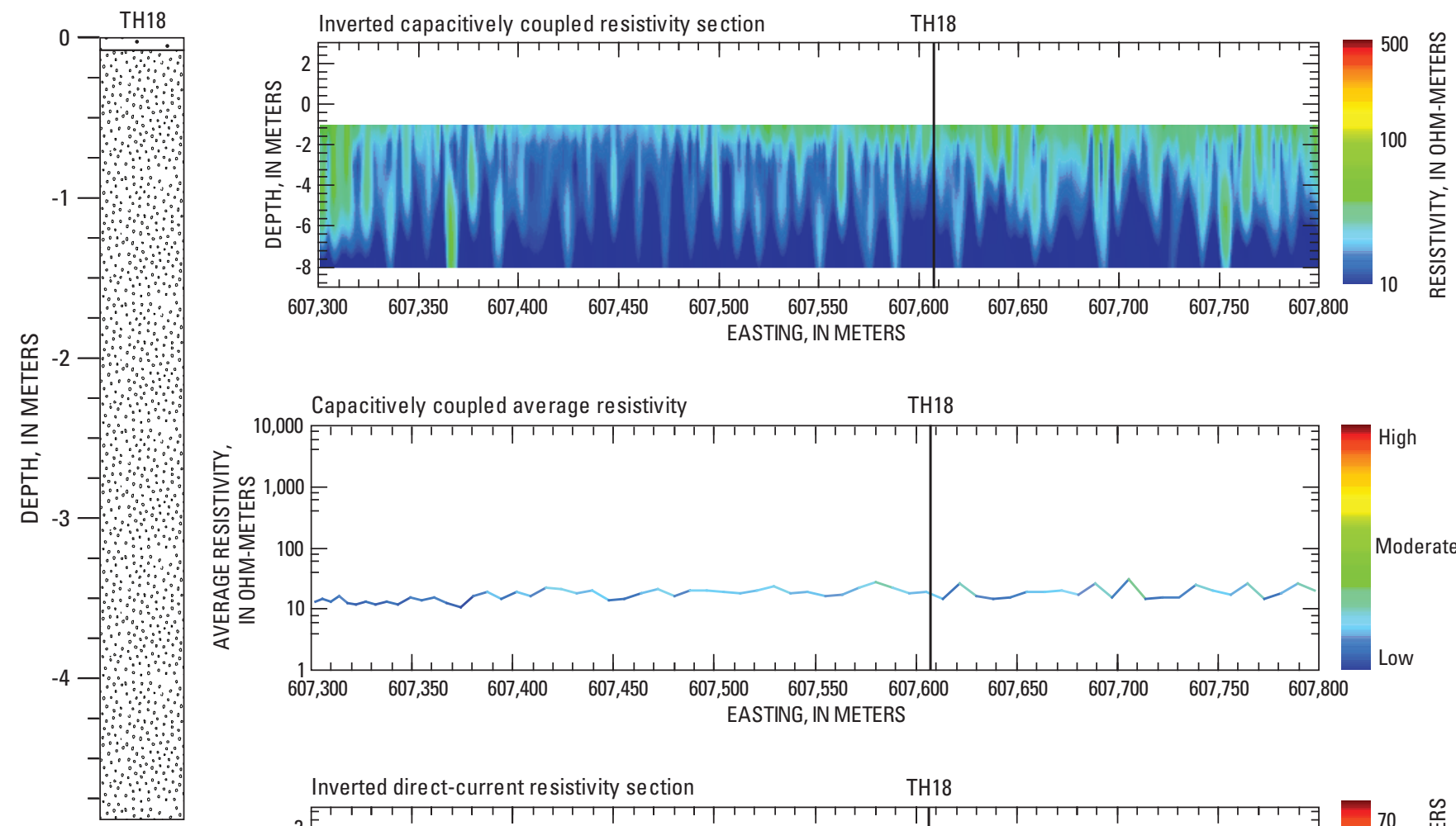

EXPLANATION

$\because \cdots$ Very fine sand

$\therefore \because$ Medium/coarse sand
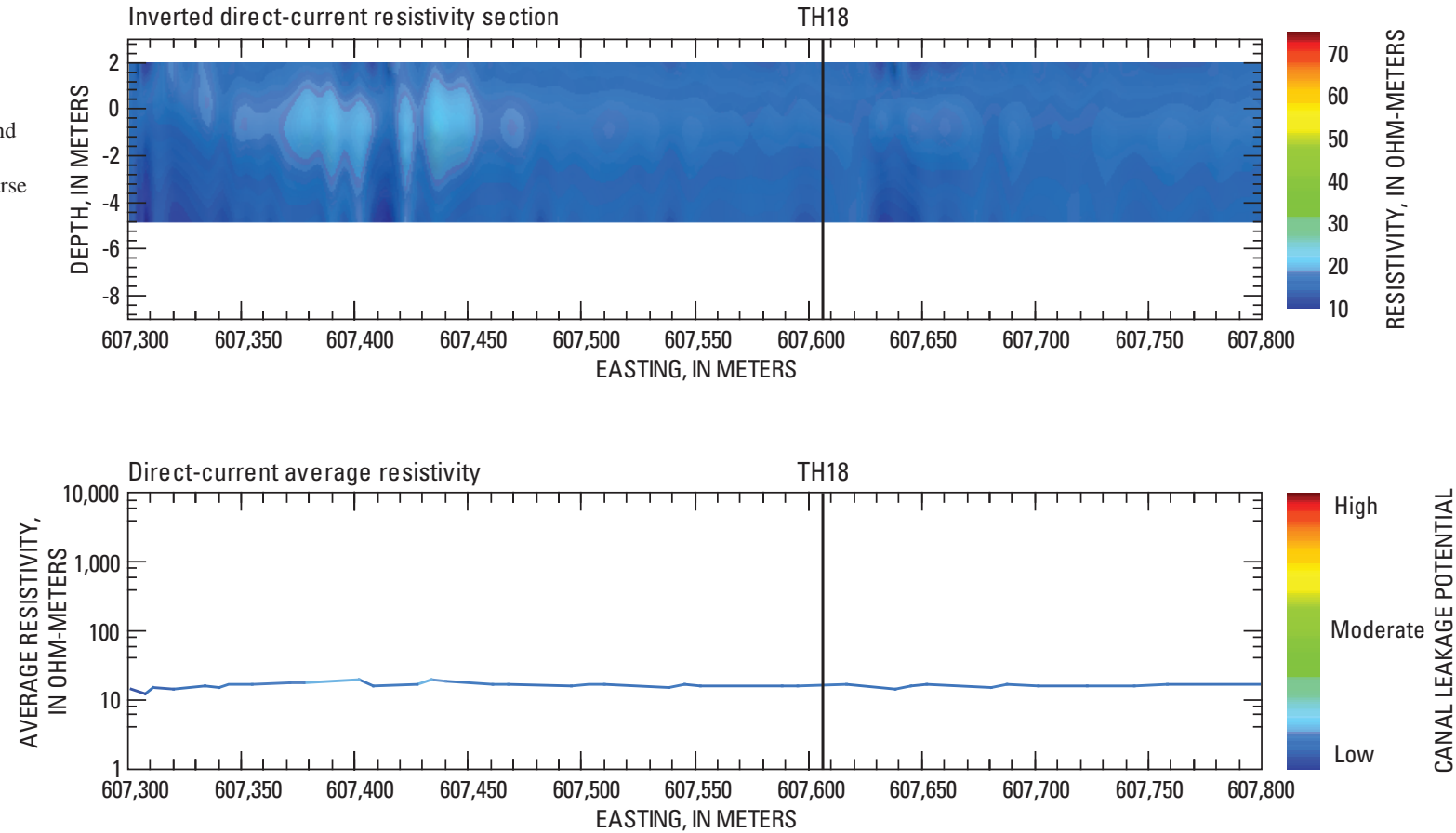

Figure 4. Comparison of $\boldsymbol{A}$, lithologic data from test hole 18 (TH18) drilled in the bed of the Interstate Canal, to $\boldsymbol{B}$, inverted capacitively coupled and direct-current resistivity sections and average resistivity curves. 
$\boldsymbol{A}$

B
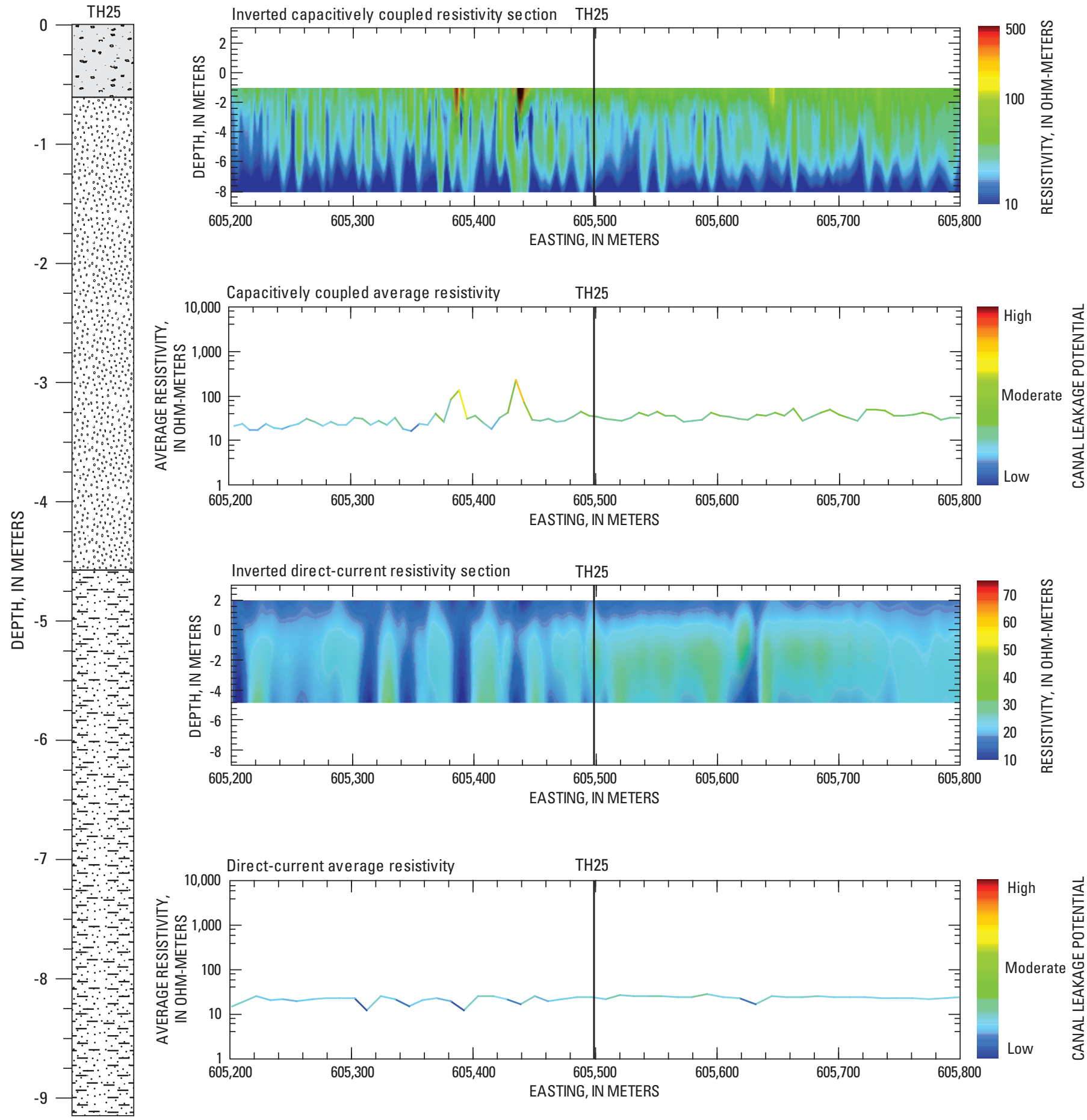

\section{EXPLANATION}

$\because \because{ }^{\prime} \because$ Moderately/poorly sorted mixed sand

$\because \cdots$ Very fine sand

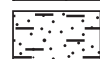

Silt and clay

Figure 5. Comparison of $\boldsymbol{A}$, lithologic data from test hole 25 (TH25) drilled in the bed of the Interstate Canal, to $\boldsymbol{B}$, inverted capacitively coupled and direct-current resistivity sections and average resistivity curves. 
$\boldsymbol{A}$

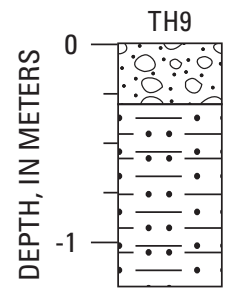

EXPLANATION $\because \because$ Sand and

B

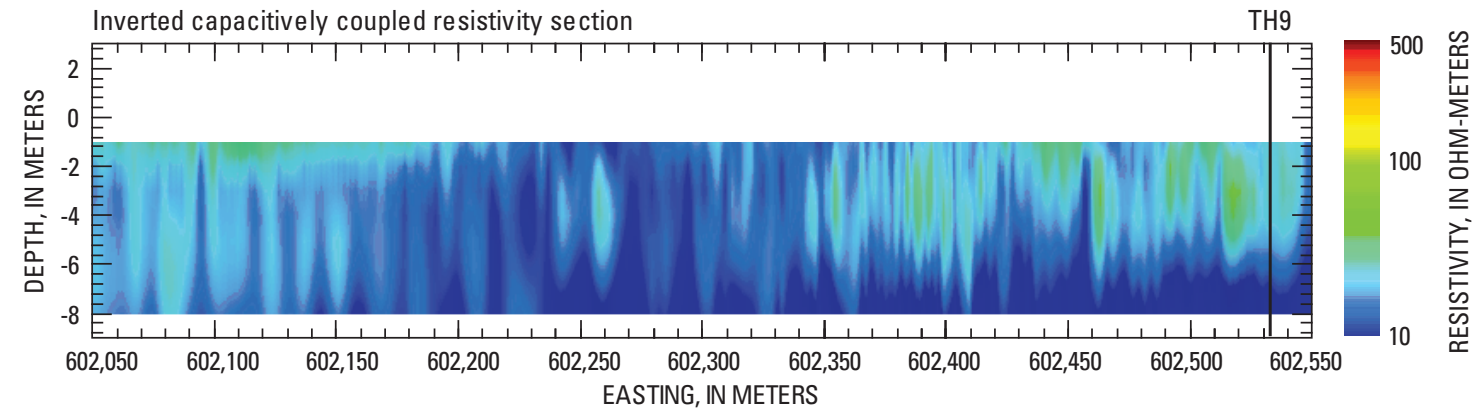

$\because \div$ Siltstone
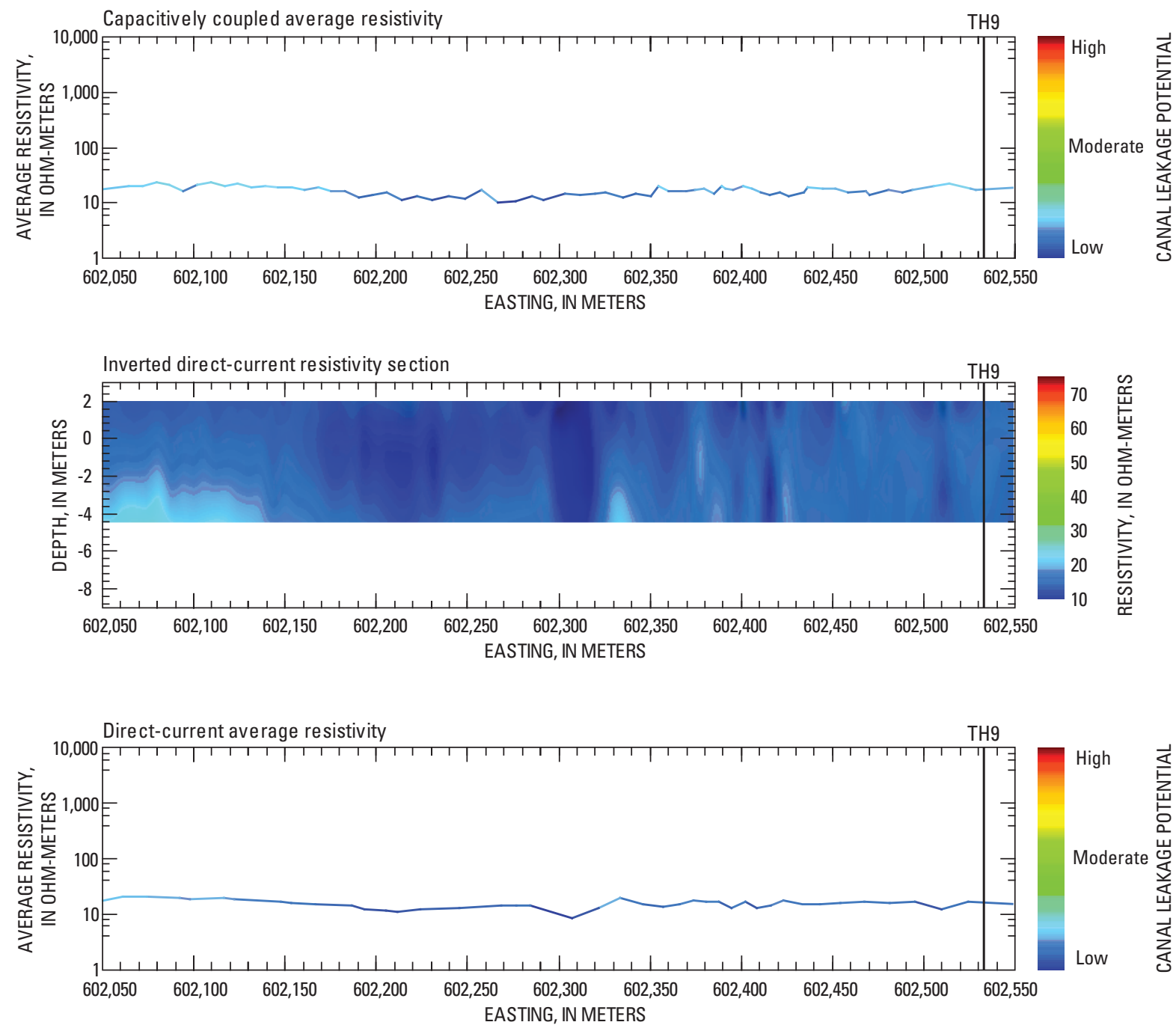

Figure 6. Comparison of $\boldsymbol{A}$, lithologic data from test hole 9 (TH9) drilled in the bed of the Interstate Canal, to $\boldsymbol{B}$, inverted capacitively coupled and direct-current resistivity sections and average resistivity curves. 
$\boldsymbol{A}$

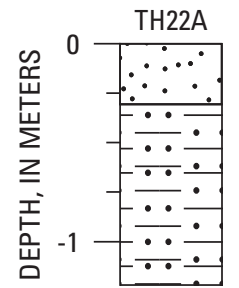

$\boldsymbol{B}$

H22A

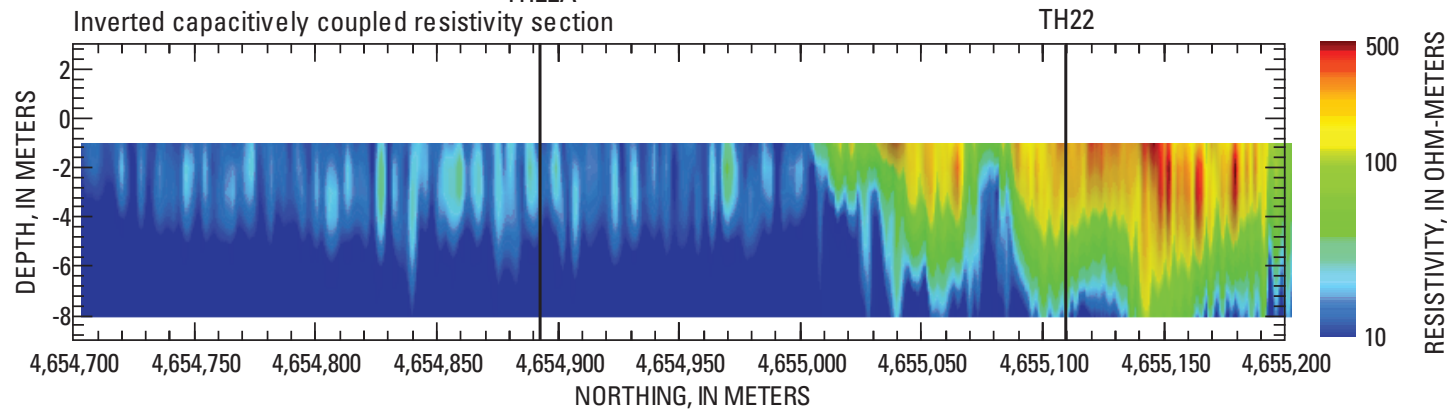

TH22A

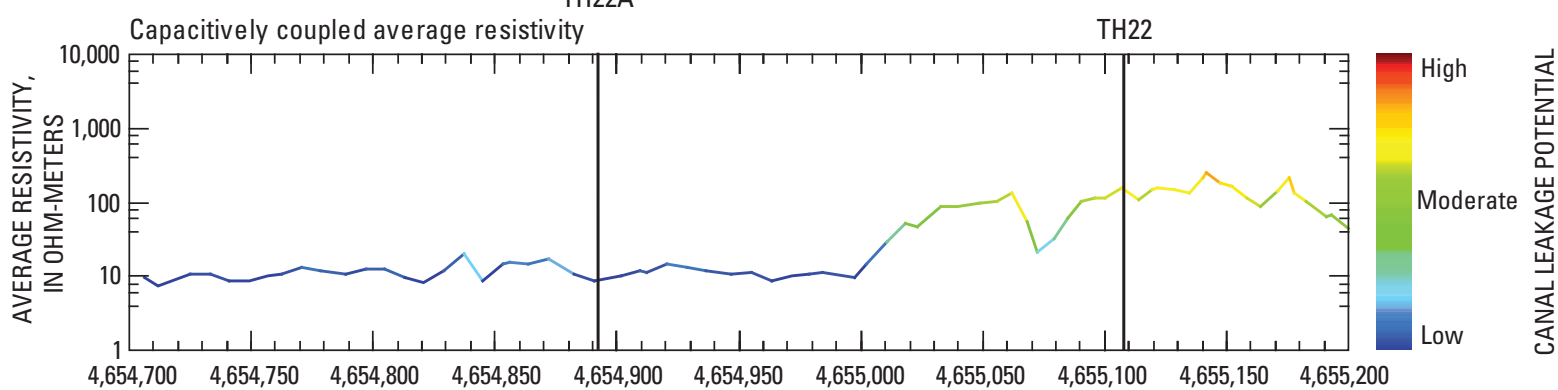

TH22A
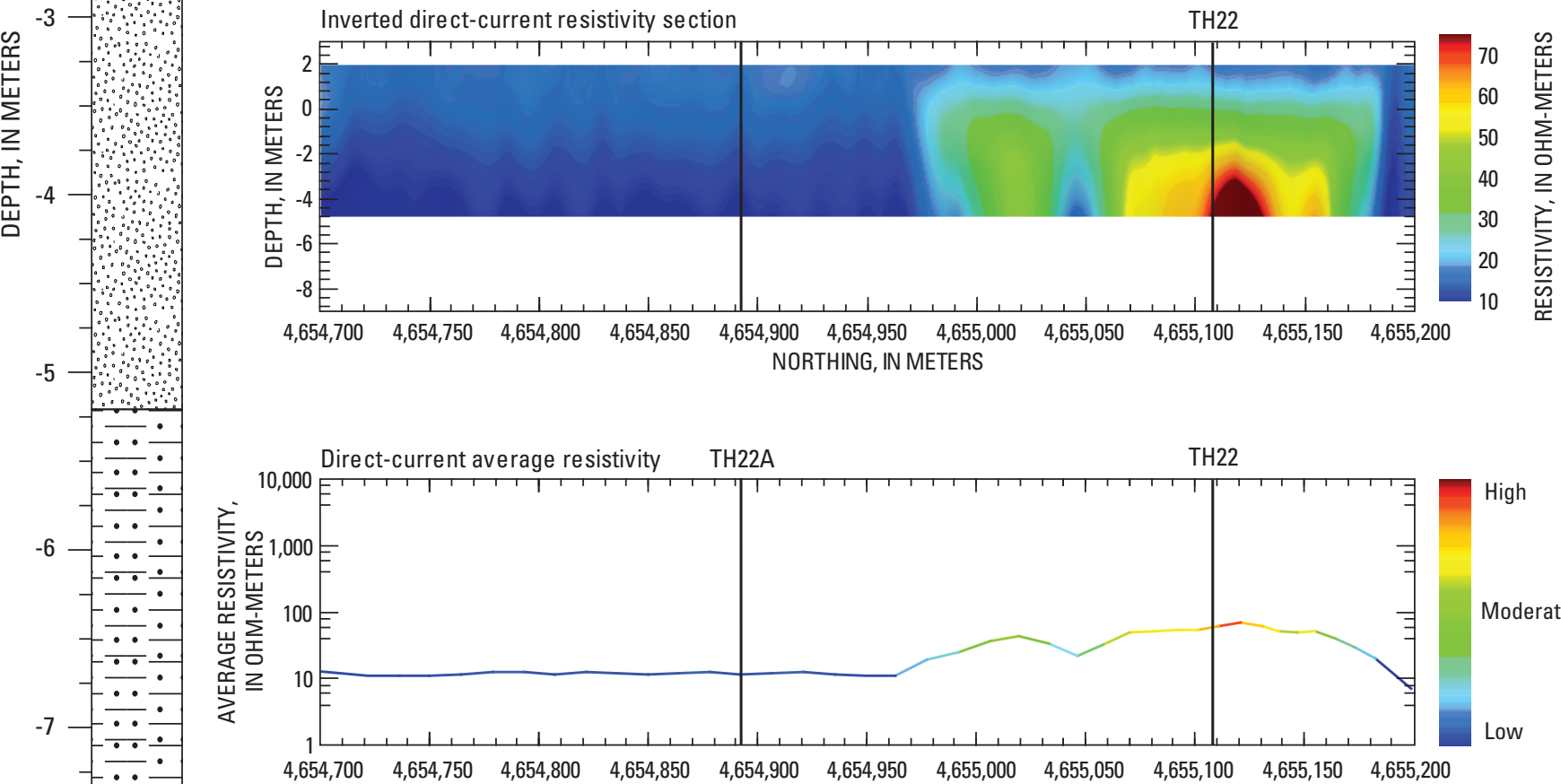

EXPLANATION
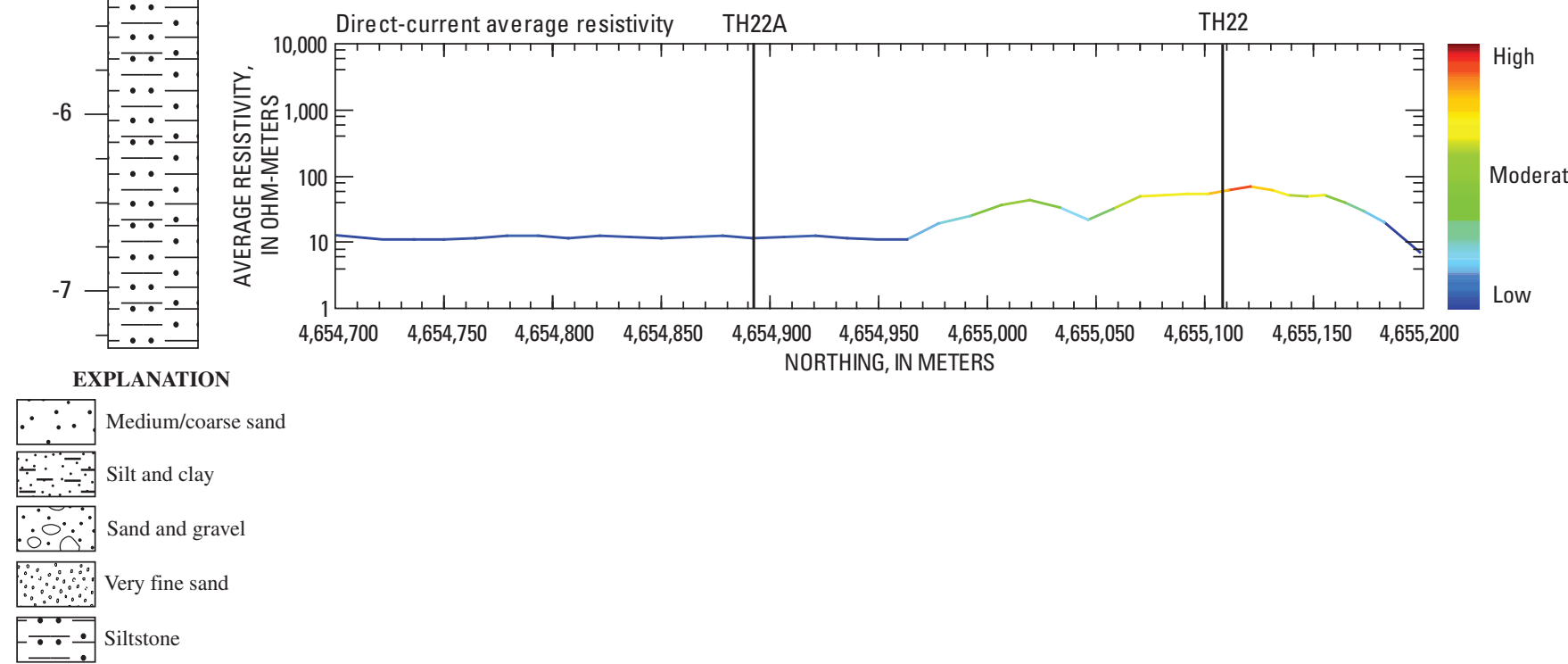

Figure 7. Comparison of $\boldsymbol{A}$, lithologic data from test holes 22 and $22 \mathrm{~A}$ (TH22 and TH22A) drilled in the bed of the Interstate Canal, to $\boldsymbol{B}$, inverted capacitively coupled and direct-current resistivity sections and average resistivity curves. 
$\boldsymbol{A}$

B
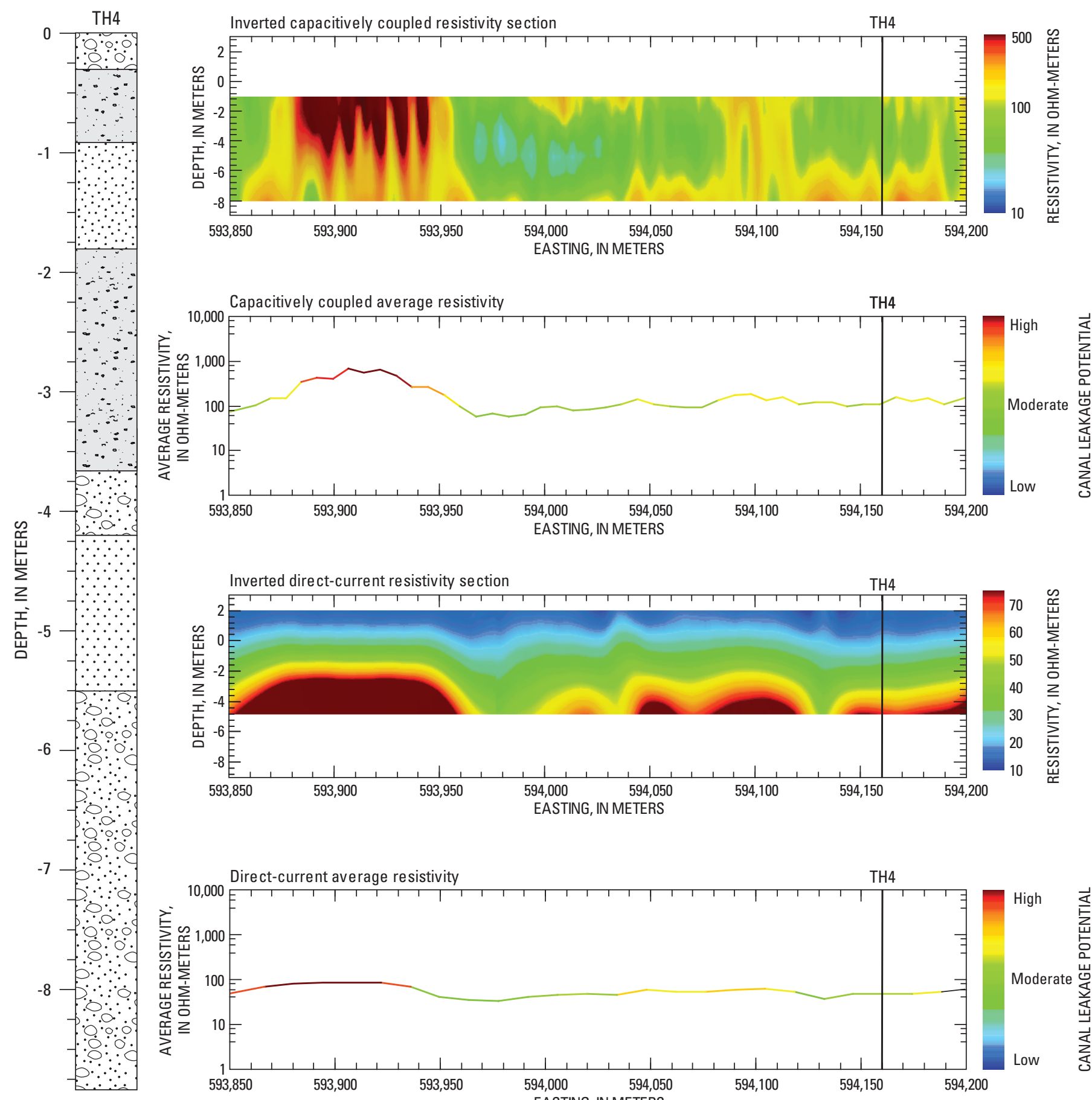

EXPLANATION

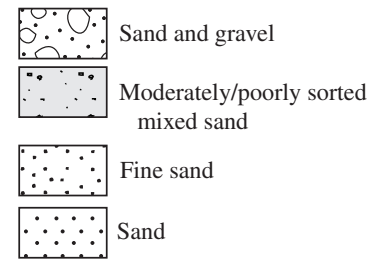

Figure 8. Comparison of $\boldsymbol{A}$, lithologic data from test hole 4 (TH4) drilled in the bed of the Interstate Canal, to $\boldsymbol{B}$, inverted capacitively coupled and direct-current resistivity sections and average resistivity curves. 
$\boldsymbol{A}$

$B$
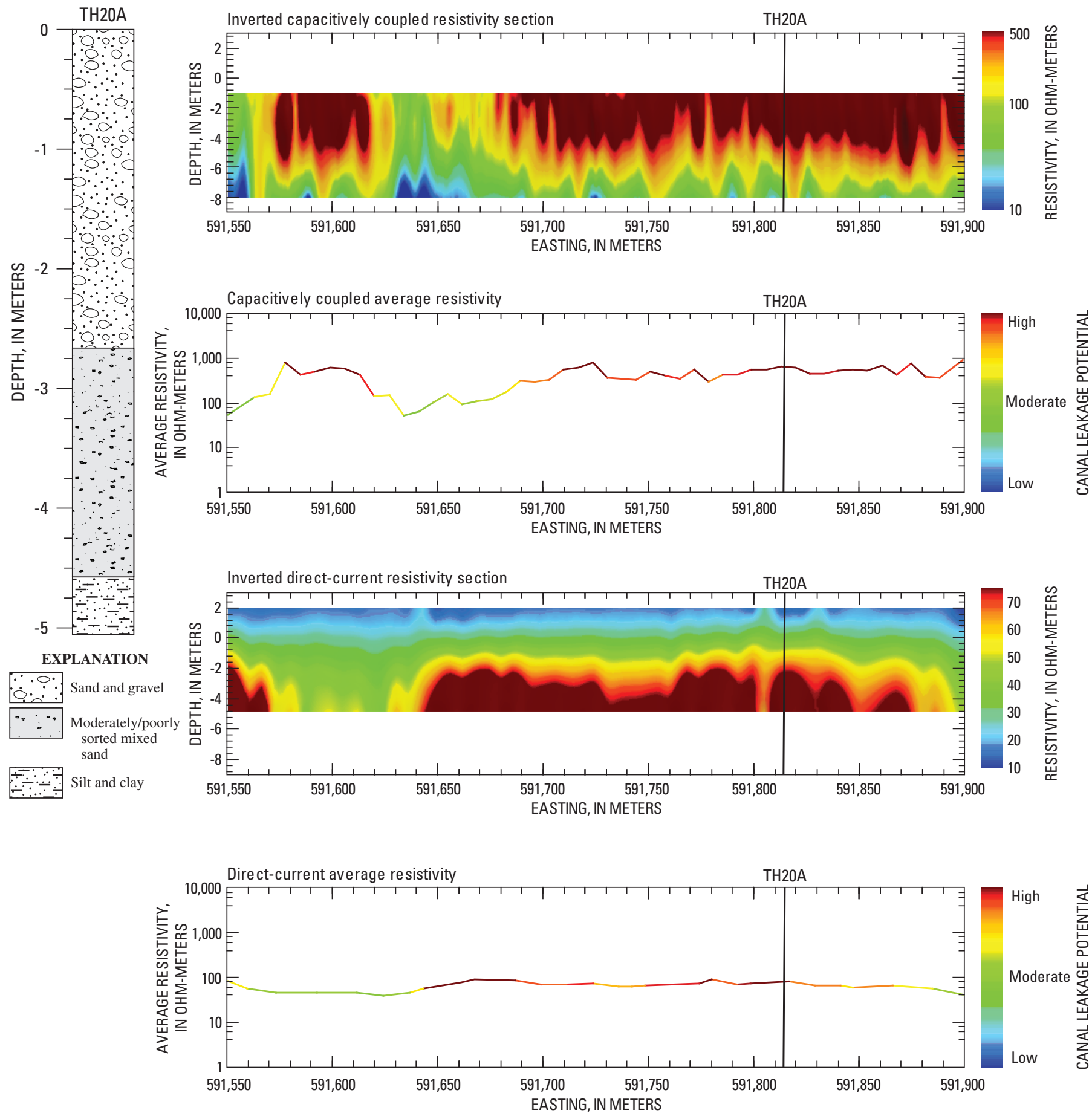

Figure 9. Comparison of $\boldsymbol{A}$, lithologic data from test hole 20A (TH20A) drilled in the bed of the Interstate Canal, to $\boldsymbol{B}$, inverted capacitively coupled and direct-current resistivity sections and average resistivity curves. 


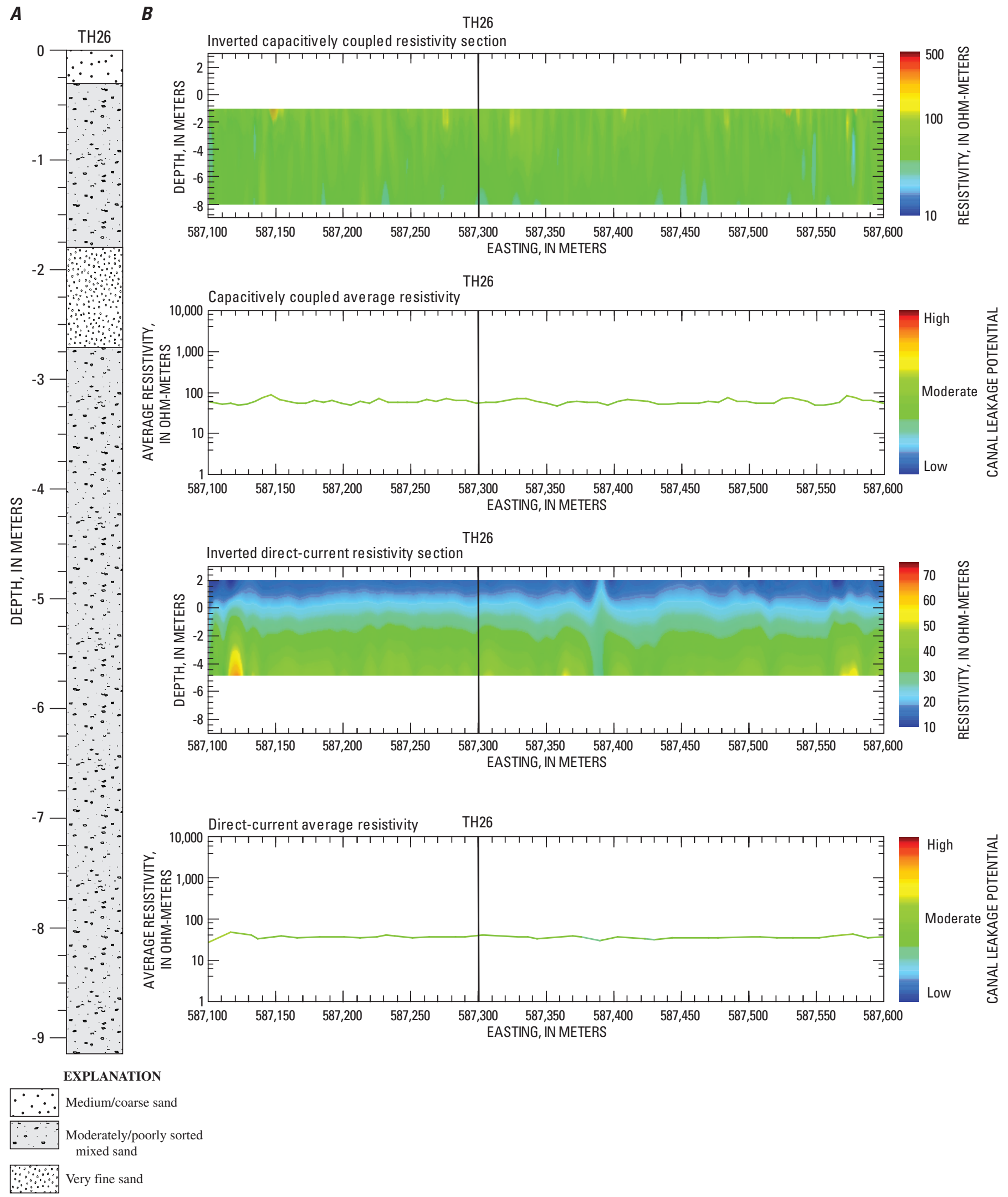

Figure 10. Comparison of $\boldsymbol{A}$, lithologic data from test hole 26 (TH26) drilled in the bed of the Interstate Canal, to $\boldsymbol{B}$, inverted capacitively coupled and direct-current resistivity sections and average resistivity curves. 

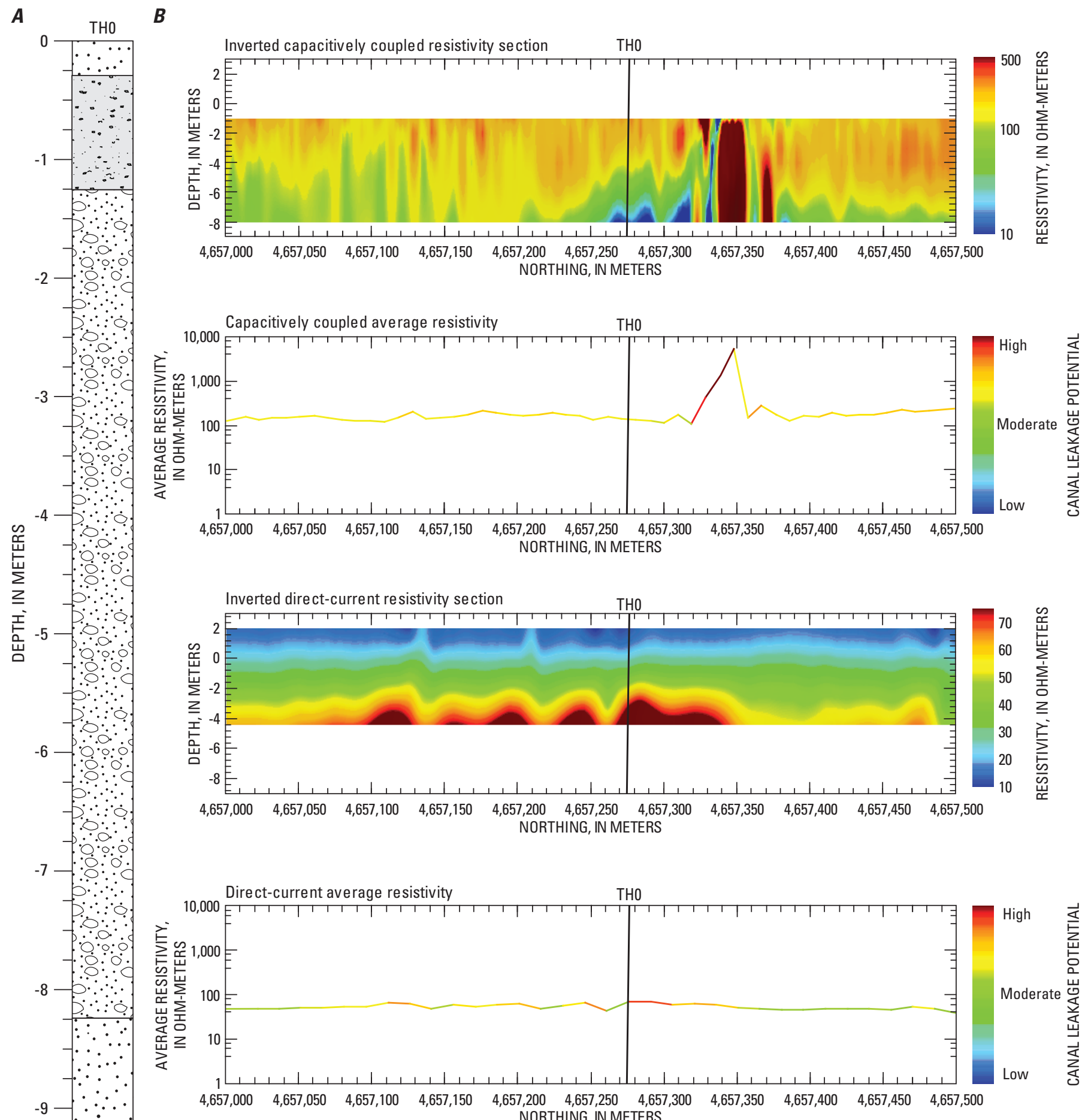

\section{EXPLANATION}

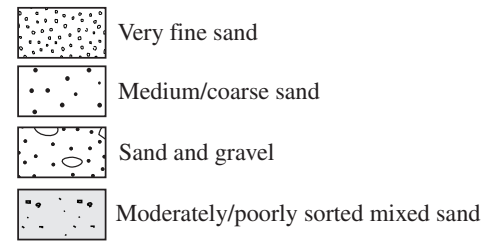

Figure 11. Comparison of $\boldsymbol{A}$, lithologic data from test hole 0 (THO) drilled in the bed of the Interstate Canal, to $\boldsymbol{B}$, inverted capacitively coupled and direct-current resistivity sections and average resistivity curves. 
$\boldsymbol{A}$ B TH15

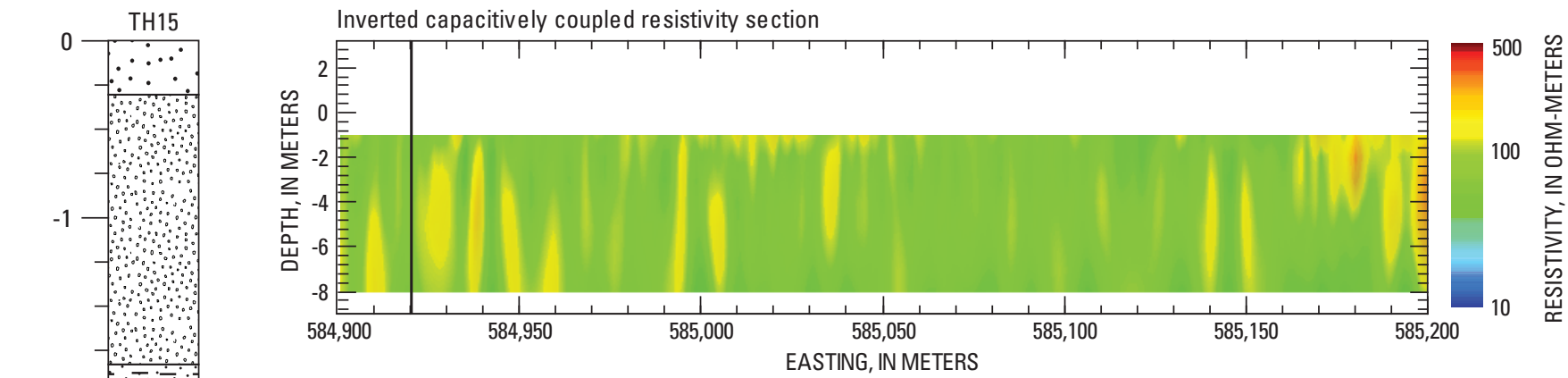

TH15

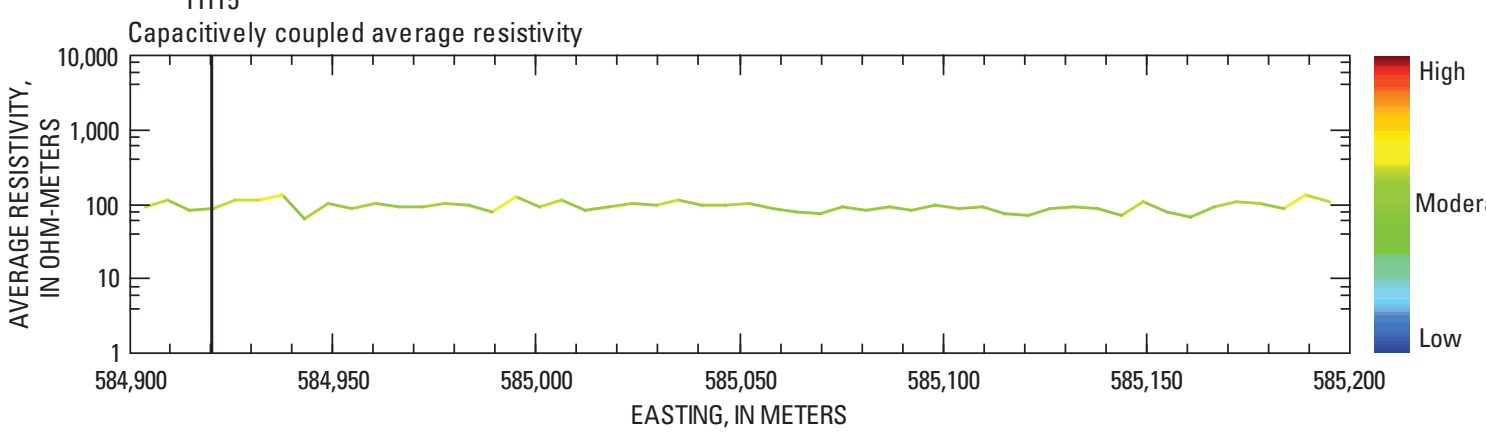

TH15

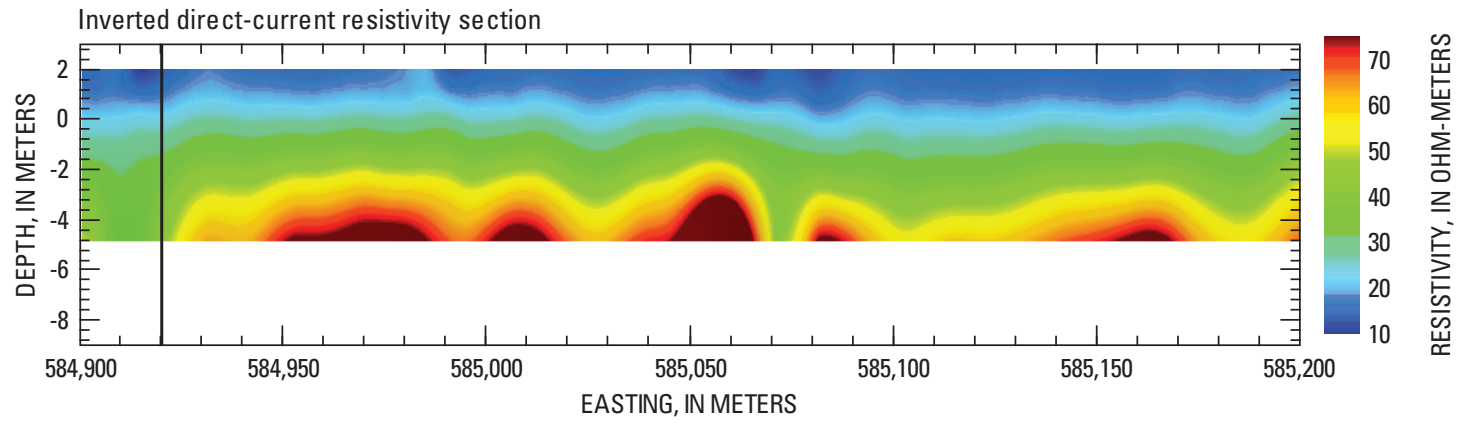

TH15
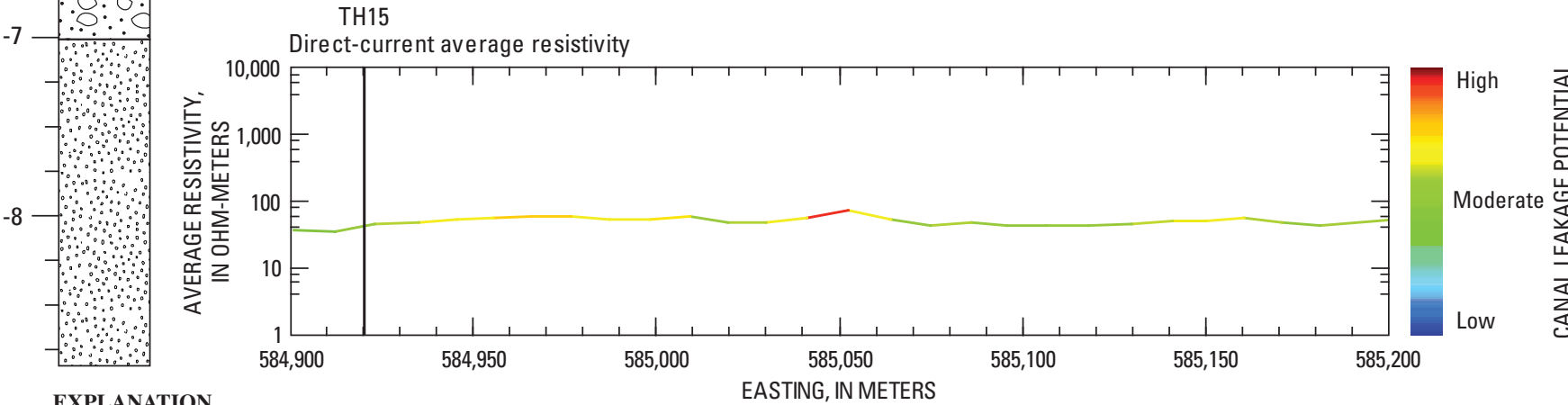

EXPLANATION

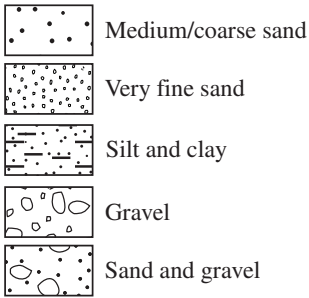

Figure 12. Comparison of $\boldsymbol{A}$, lithologic data from test hole 15 (TH15) drilled in the bed of the Interstate Canal, to $\boldsymbol{B}$, inverted capacitively coupled and direct-current resistivity sections and average resistivity curves. 
A

\section{B}
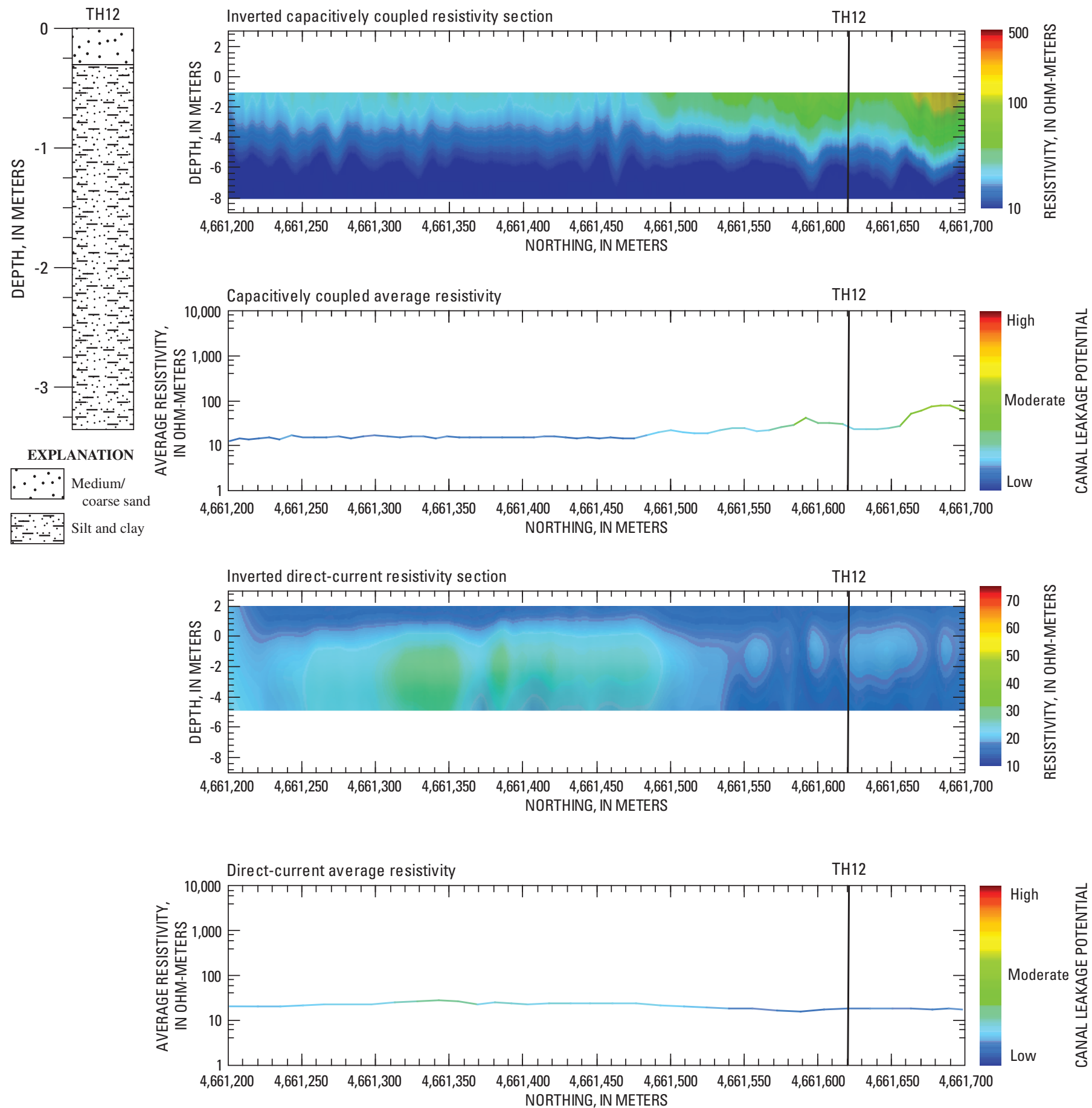

Figure 13. Comparison of $\boldsymbol{A}$, lithologic data from test hole 12 (TH12) drilled in the bed of the Interstate Canal, to $\boldsymbol{B}$, inverted capacitively coupled and direct-current resistivity sections and average resistivity curves. 
$\boldsymbol{A}$

B
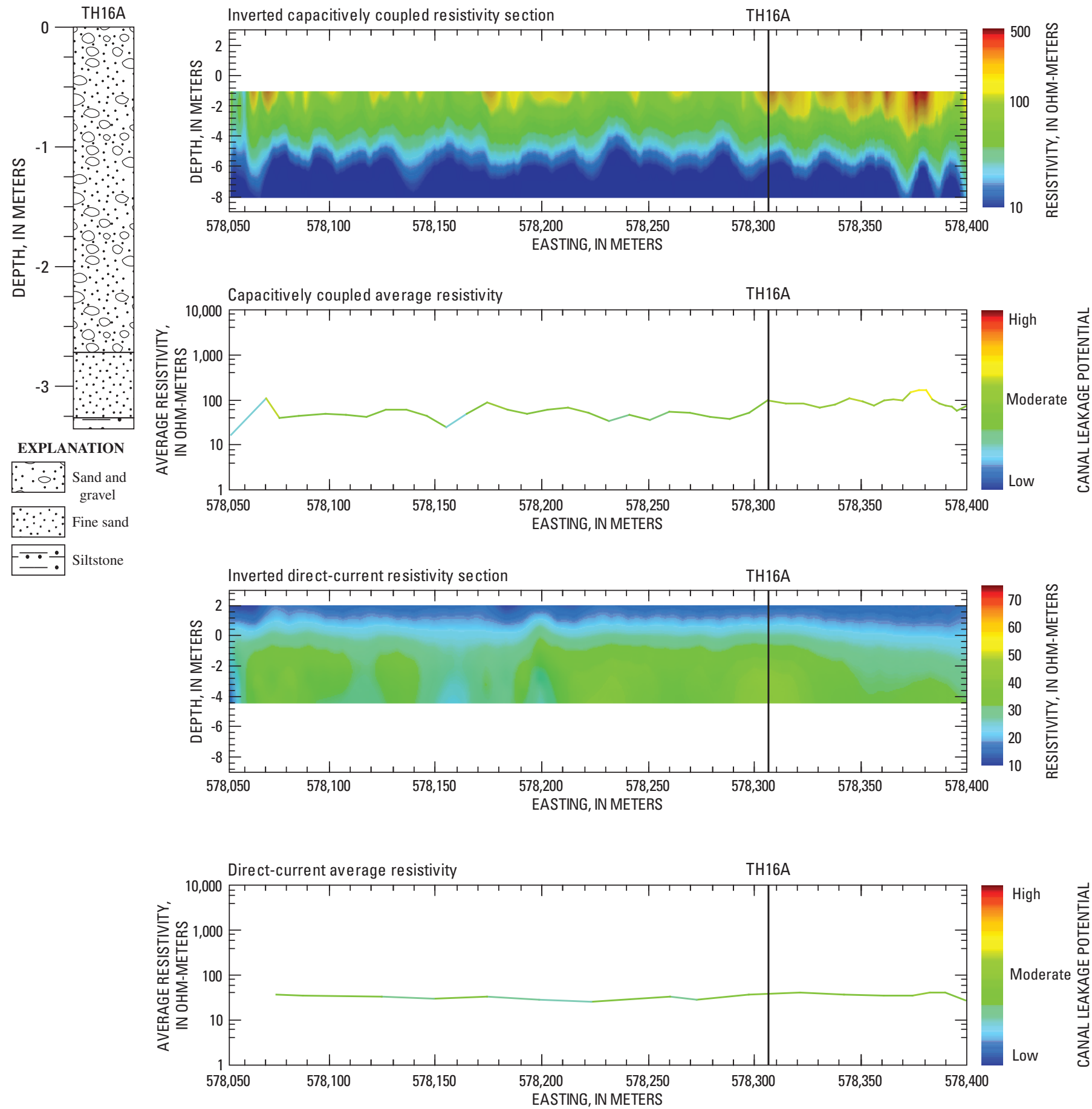

Figure 14. Comparison of $\boldsymbol{A}$, lithologic data from test hole 16A (TH16A) drilled in the bed of the Interstate Canal, to $\boldsymbol{B}$, inverted capacitively coupled and direct-current resistivity sections and average resistivity curves. 
A

B

TH11A

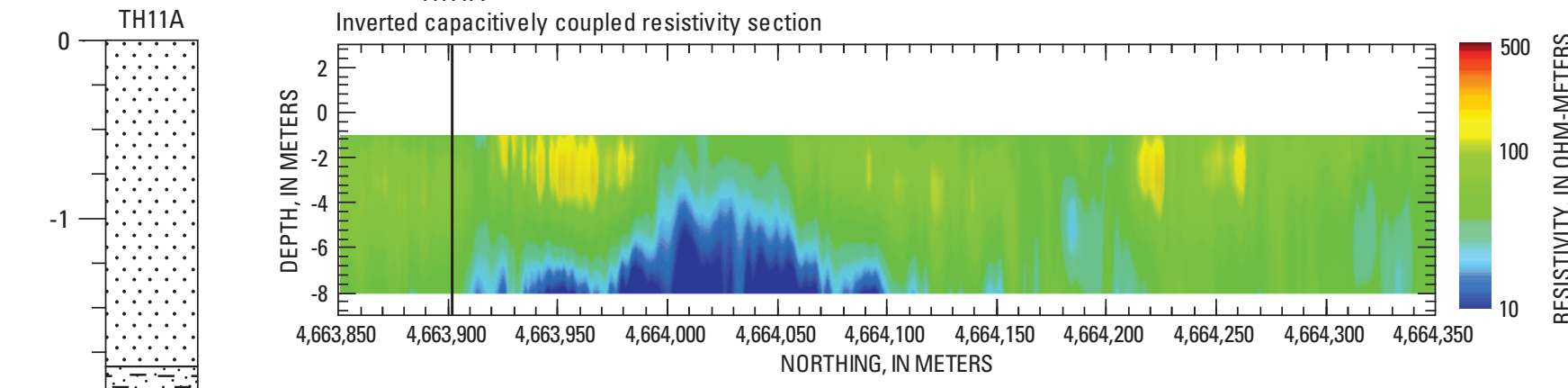

TH11A
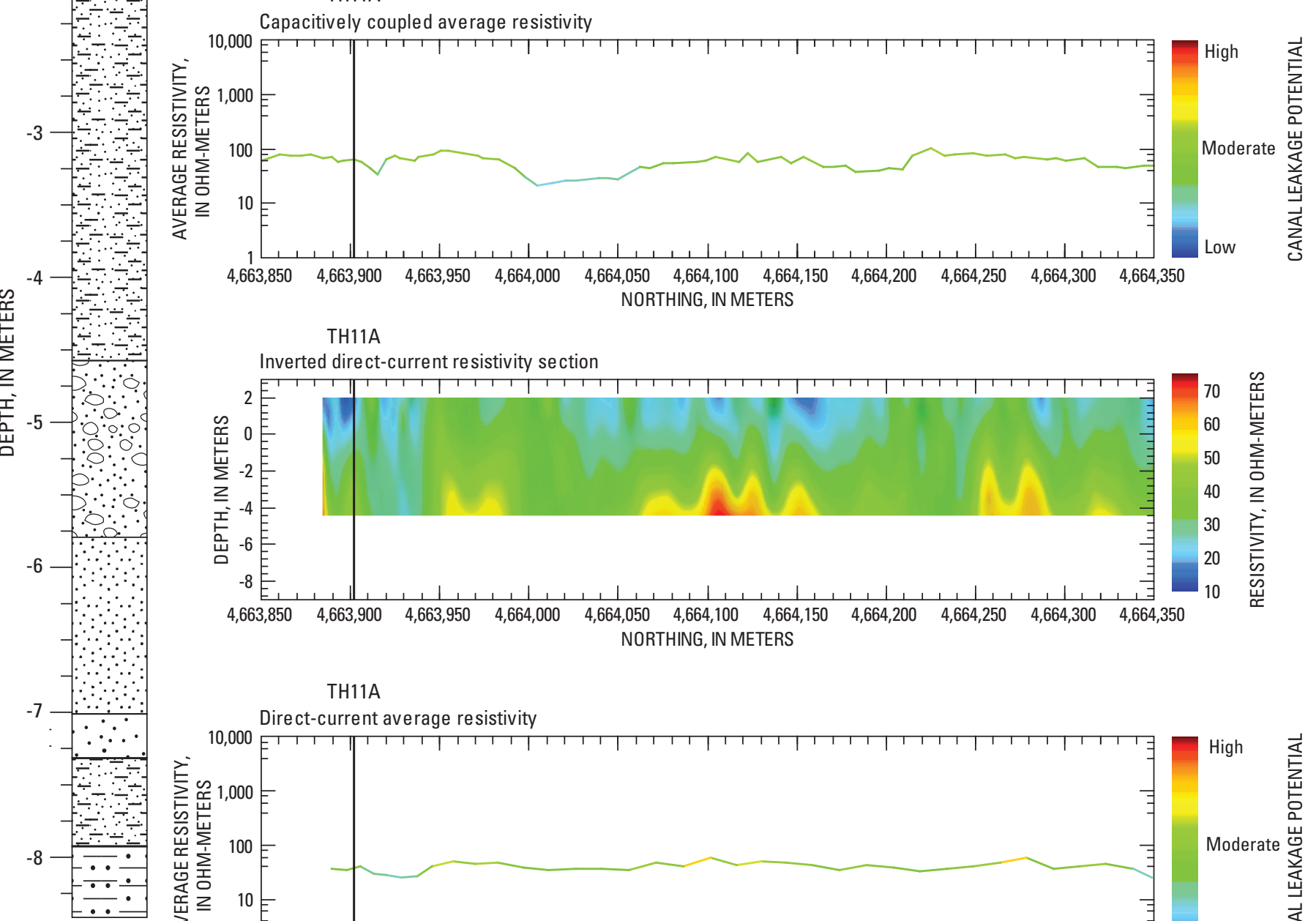

$\begin{array}{rrrrrrr}4,663,850 & 4,663,900 & 4,663,950 & 4,664,000 & 4,664,050 & 4,664,100 & 4,664,\end{array}$

TH11A

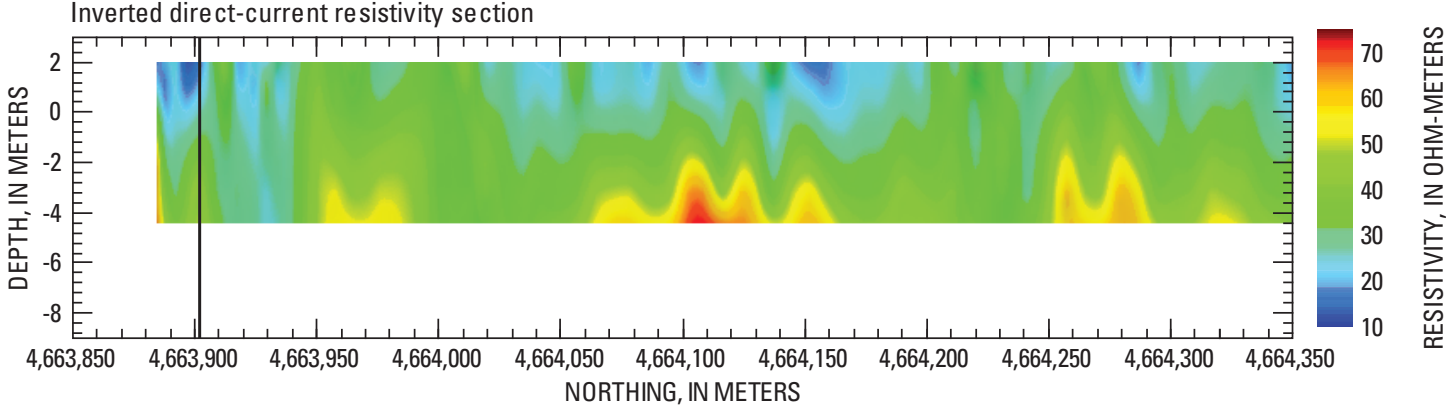

EXPLANATION

\begin{tabular}{|c|c|}
\hline$\because$ & Sand \\
\hline$\because$ & Silt and clay \\
\hline & Sand and gravel \\
\hline & Fine sand \\
\hline & Medium/coarse sar \\
\hline$\div$. & Siltstone \\
\hline
\end{tabular}

TH11A

irect-current average resistivity

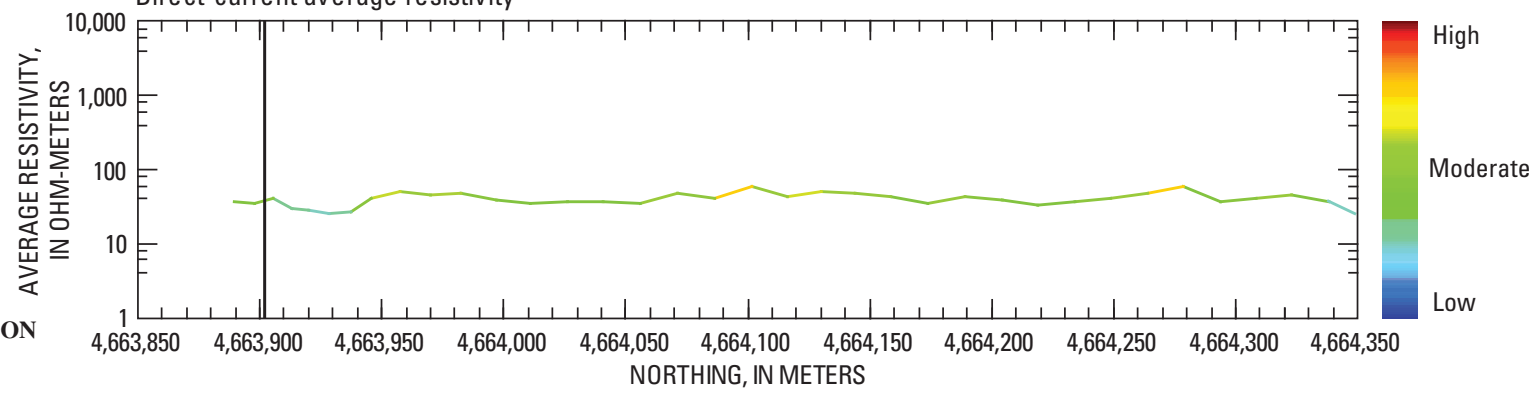

Figure 15. Comparison of $\boldsymbol{A}$, lithologic data from test hole 11A (TH11A) drilled in the bed of the Interstate Canal, to $\boldsymbol{B}$, inverted capacitively coupled and direct-current resistivity sections and average resistivity curves. 
$\boldsymbol{A}$

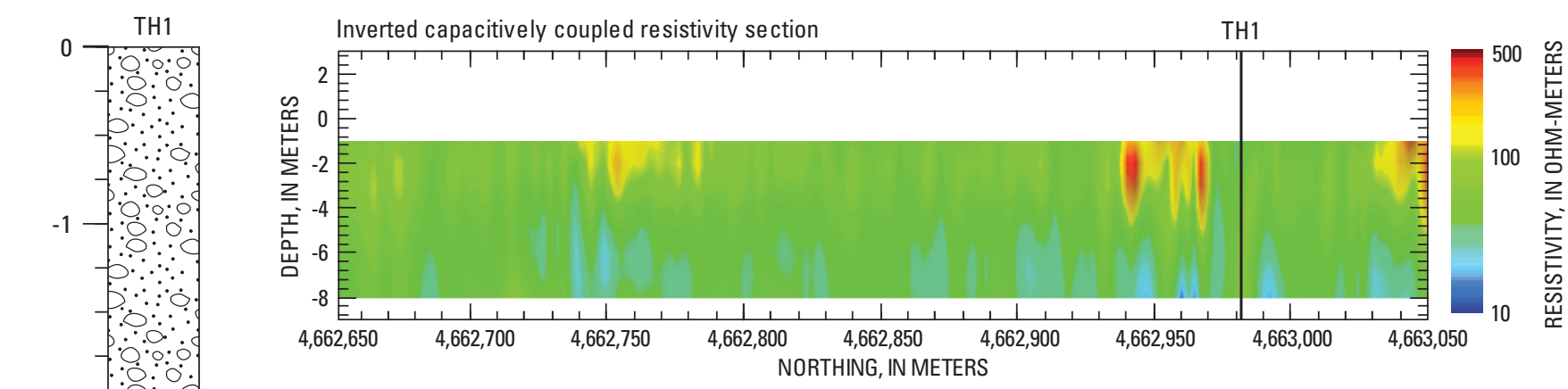

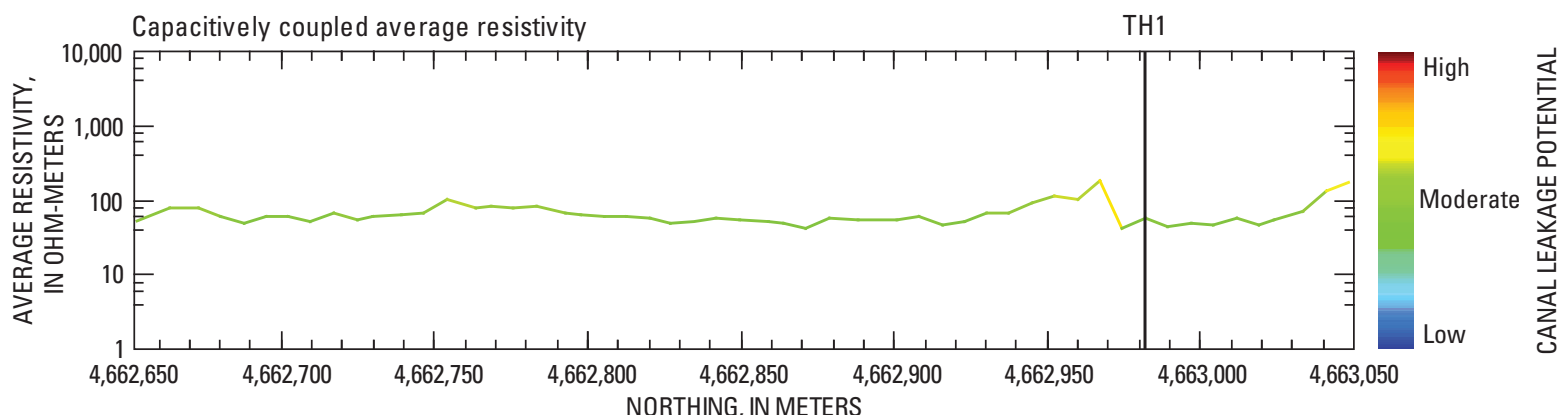
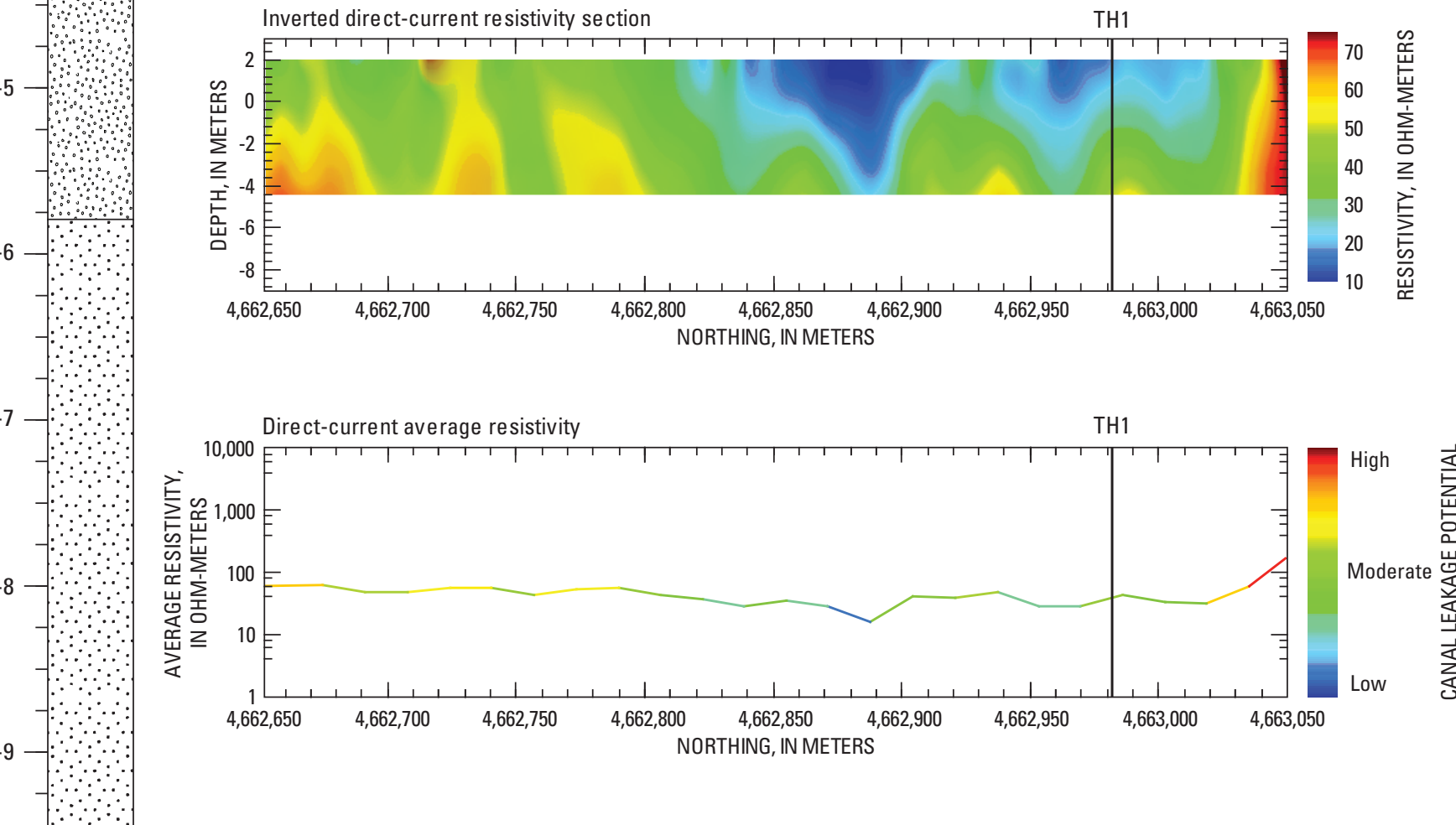

EXPLANATION

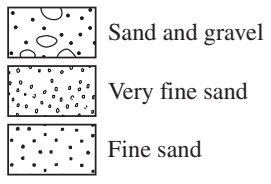

Figure 16. Comparison of $\boldsymbol{A}$, lithologic data from test hole 1 (TH1) drilled in the bed of the Interstate Canal, to $\boldsymbol{B}$, inverted capacitively coupled and direct-current resistivity sections and average resistivity curves. 

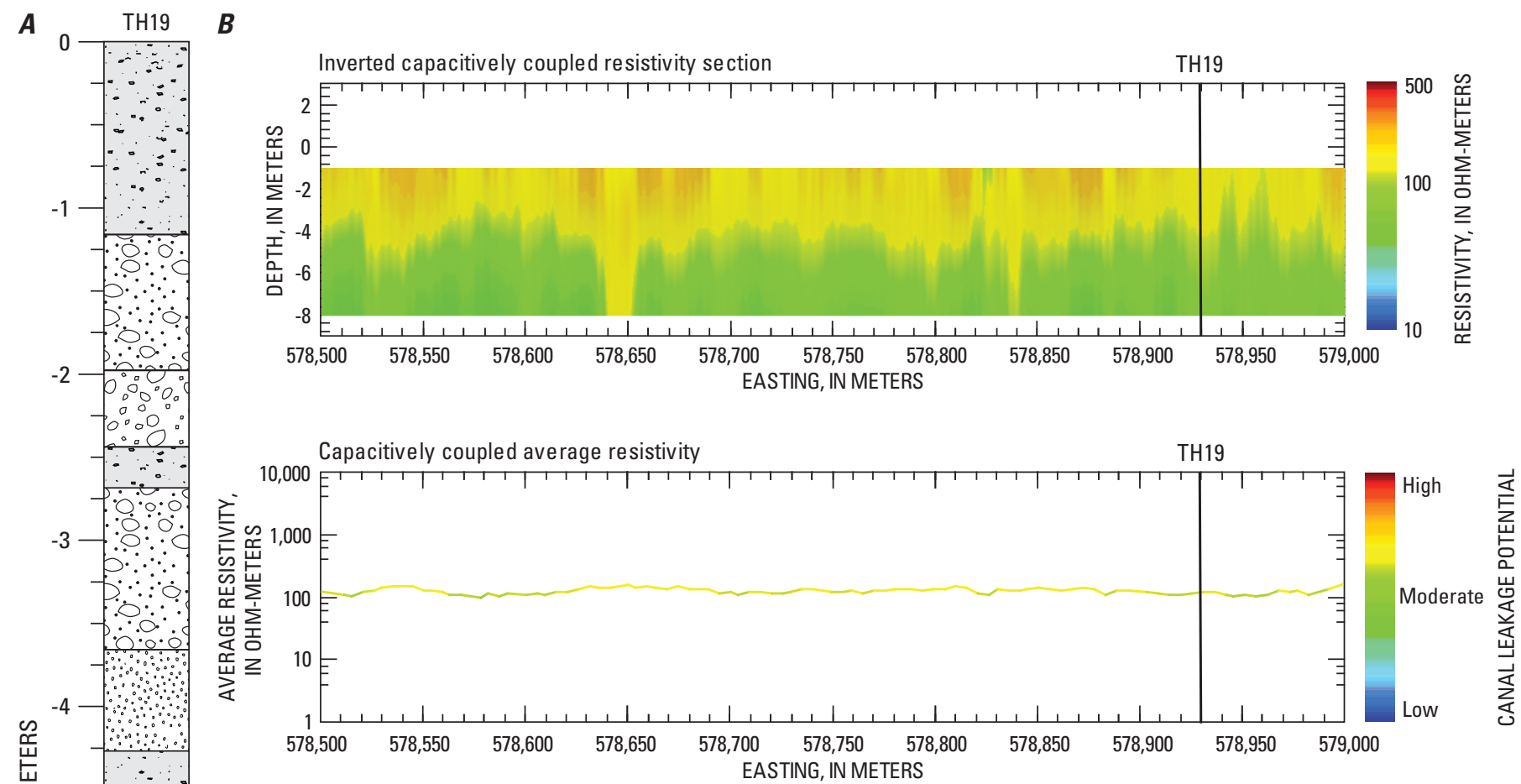

\section{EXPLANATION}

$\because \quad$ Moderately/poorly sorted

mixed sand

$\because \because$ Sand and gravel

$-8-\because \div=$

60.0. Gravel

$\because \because \because$ Very fine sand

$-9-\because \because \because$ Sand

Figure 17. Comparison of $\boldsymbol{A}$, lithologic data from test hole 19 (TH19) drilled in the bed of the Interstate Canal, to $\boldsymbol{B}$, the inverted capacitively coupled section and average resistivity curve. The direct-current resistivity data were severely compromised by breakdowns in the electrode connections of the water-borne resistivity cable and are not shown. 
$\boldsymbol{A}$

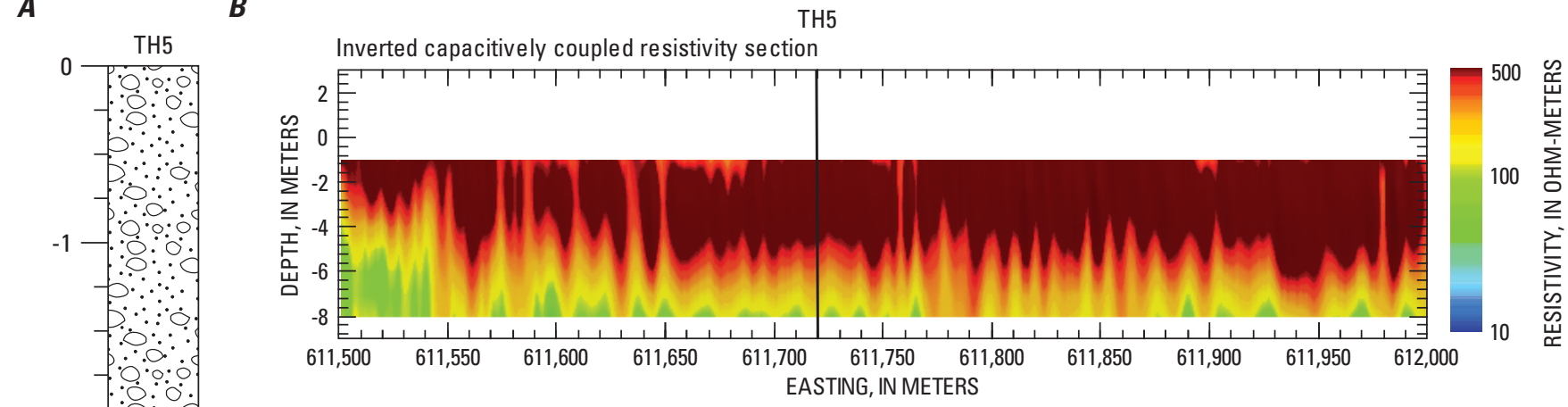

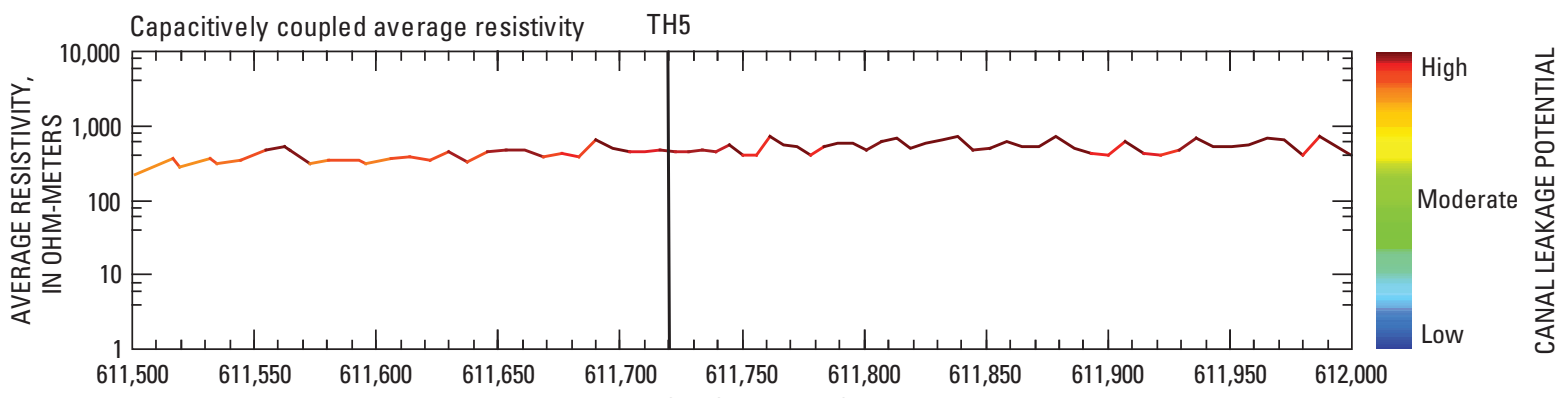
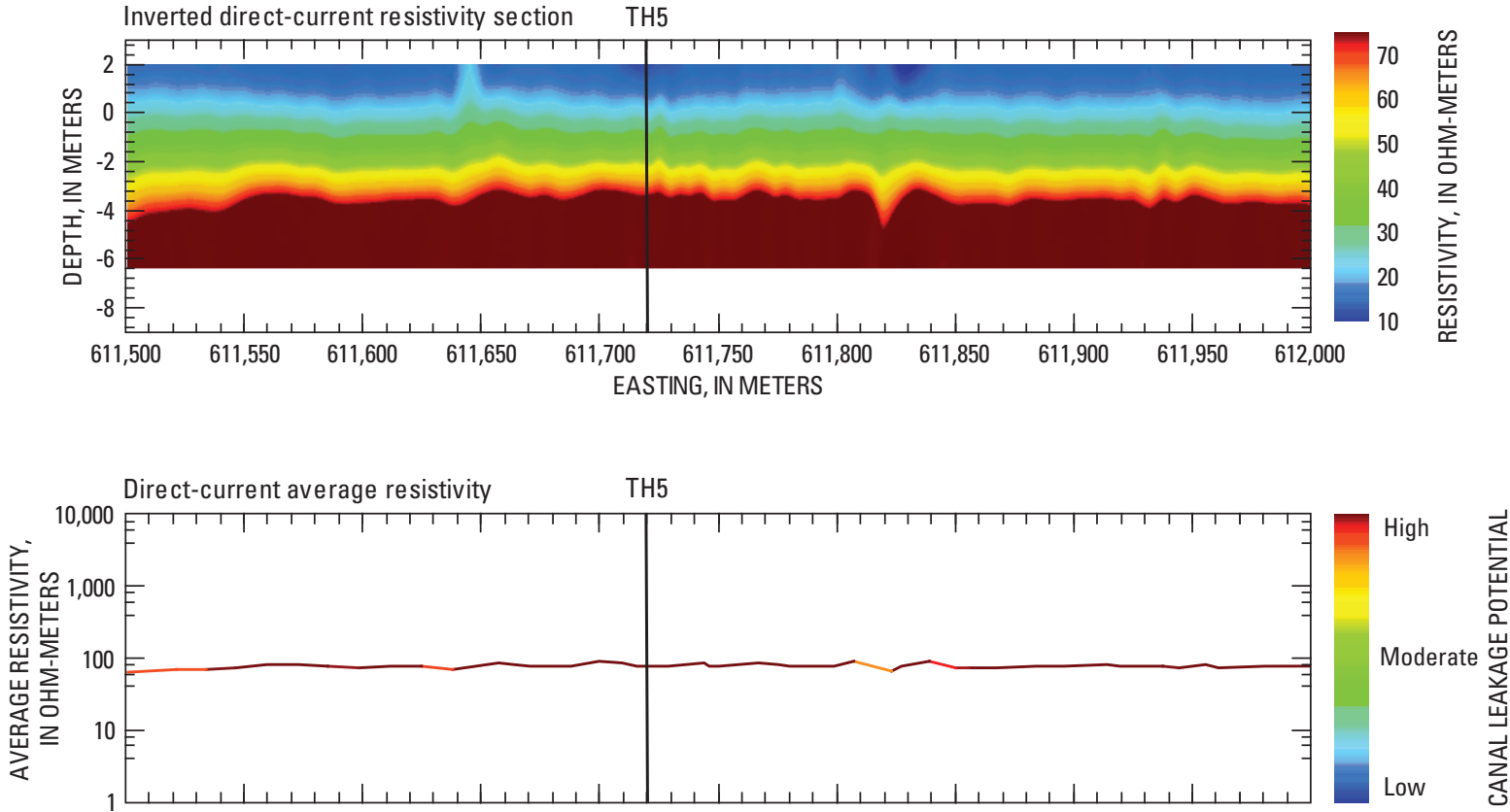

EXPLANATION

$\because \because \because$ Sand and gravel
$\because \because \because$ Medium/coarse $_{\text {Sand }}$

Figure 18. Comparison of $\boldsymbol{A}$, lithologic data from test hole 5 (TH5) drilled in the bed of the Tri-State Canal, to $\boldsymbol{B}$, inverted capacitively coupled and direct-current resistivity sections and average resistivity curves. 
$\boldsymbol{A}$

$B$
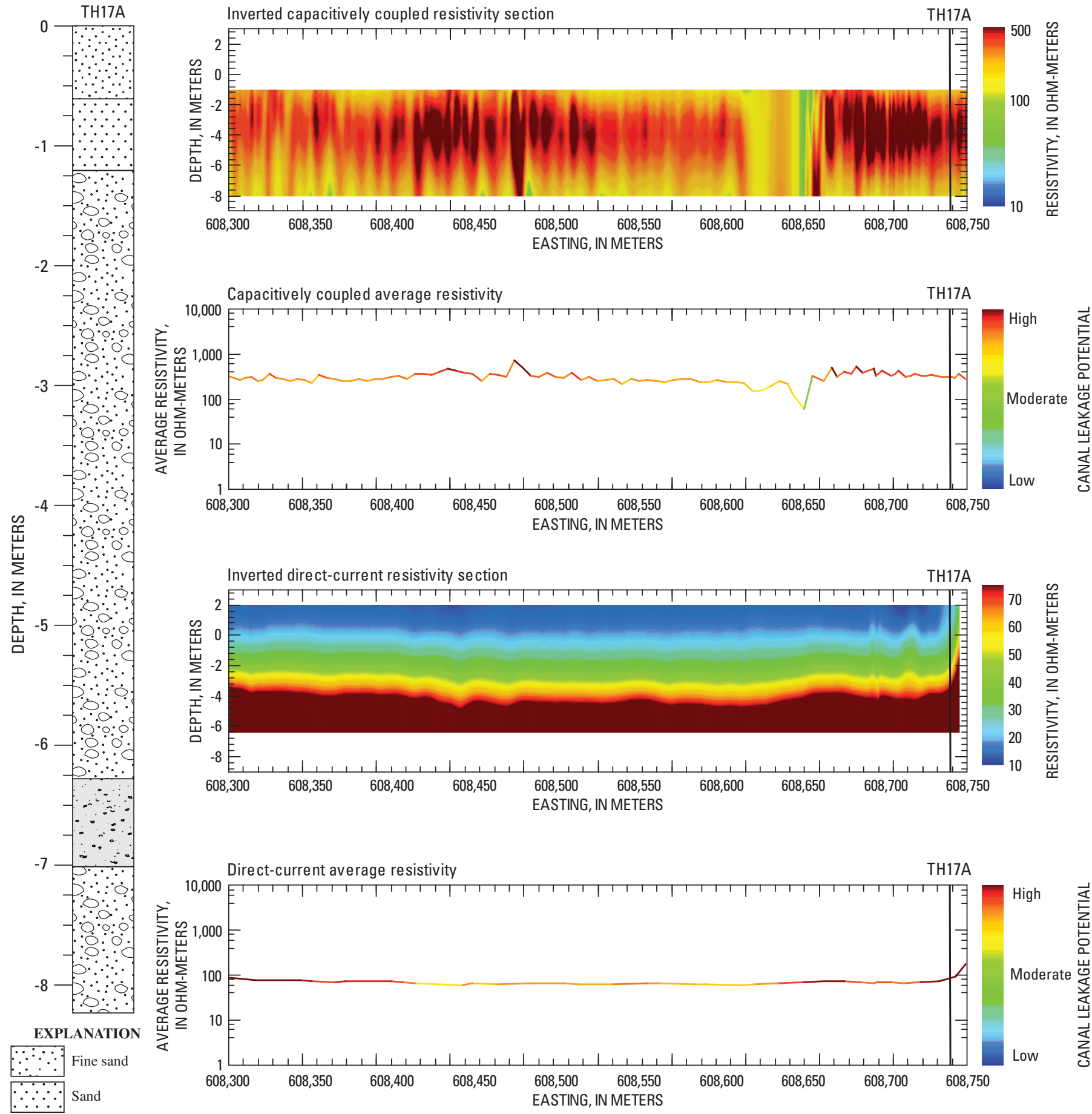

Figure 19. Comparison of $\boldsymbol{A}$, lithologic data from test hole 17A (TH17A) drilled in the bed of the Tri-State Canal, to $\boldsymbol{B}$, inverted capacitively coupled and direct-current resistivity sections and average resistivity curves. 
$\boldsymbol{A}$

B
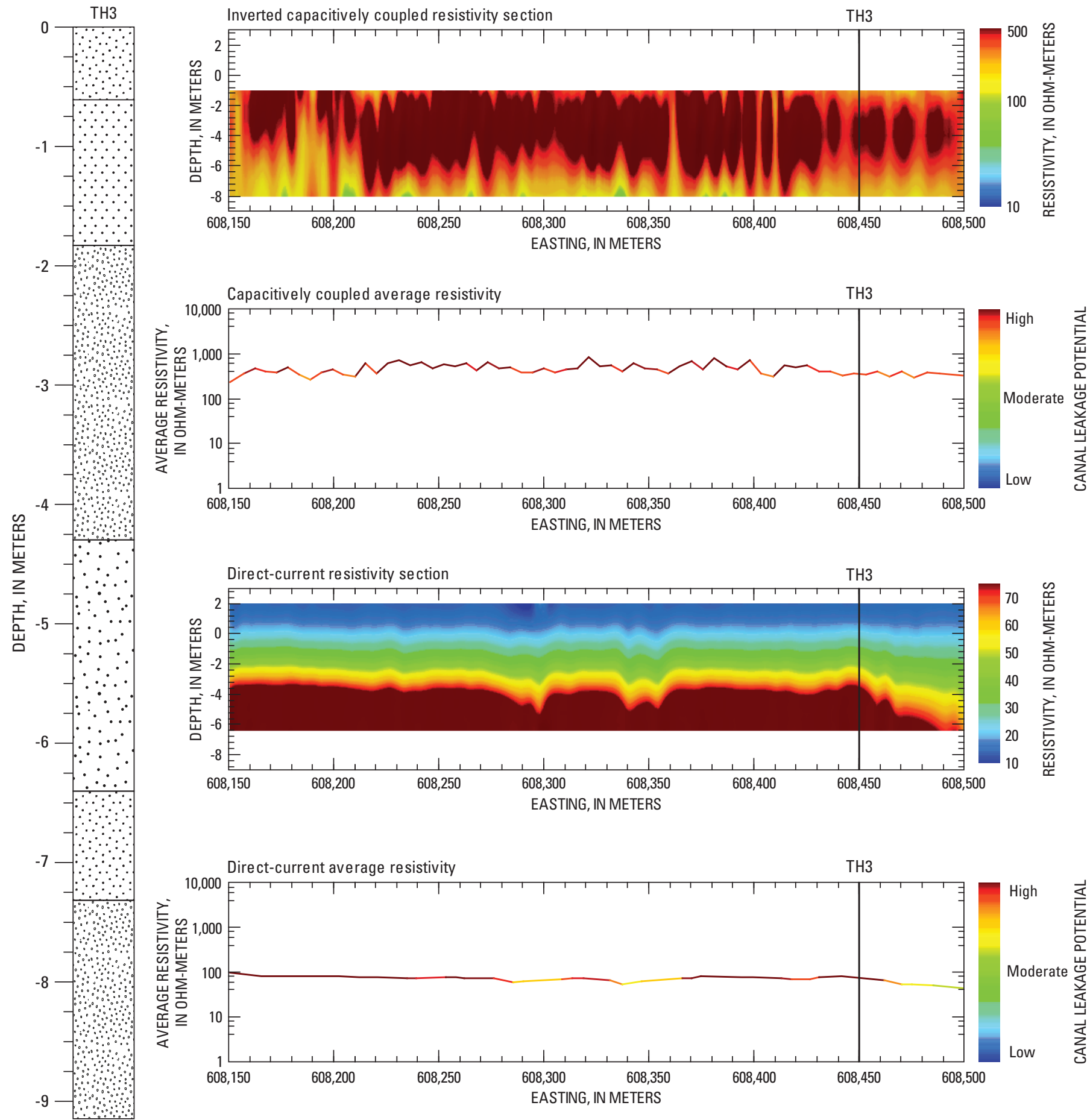

EXPLANATION

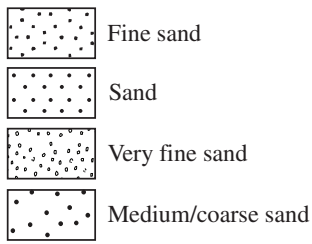

Figure 20. Comparison of $\boldsymbol{A}$, lithologic data from test hole $3(\mathrm{TH} 3)$ drilled in the bed of the Tri-State Canal, to $\boldsymbol{B}$, inverted capacitively coupled and direct-current resistivity sections and average resistivity curves. 
A

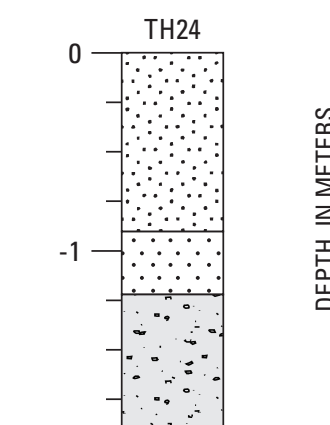

TH24

Inverted capacitively coupled resistivity section

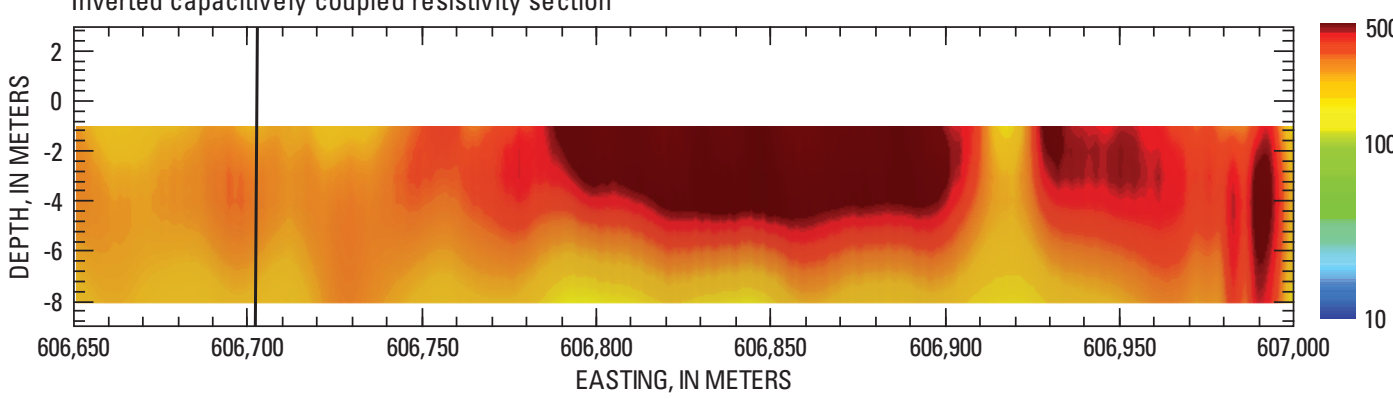

$\mathrm{TH} 24$

Capacitively coupled average resistivity

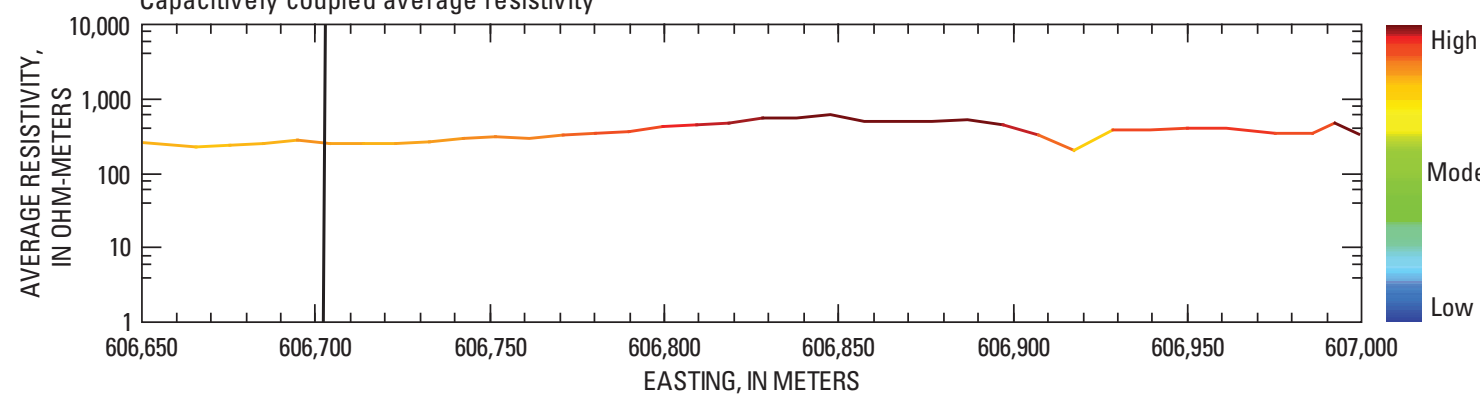

TH24

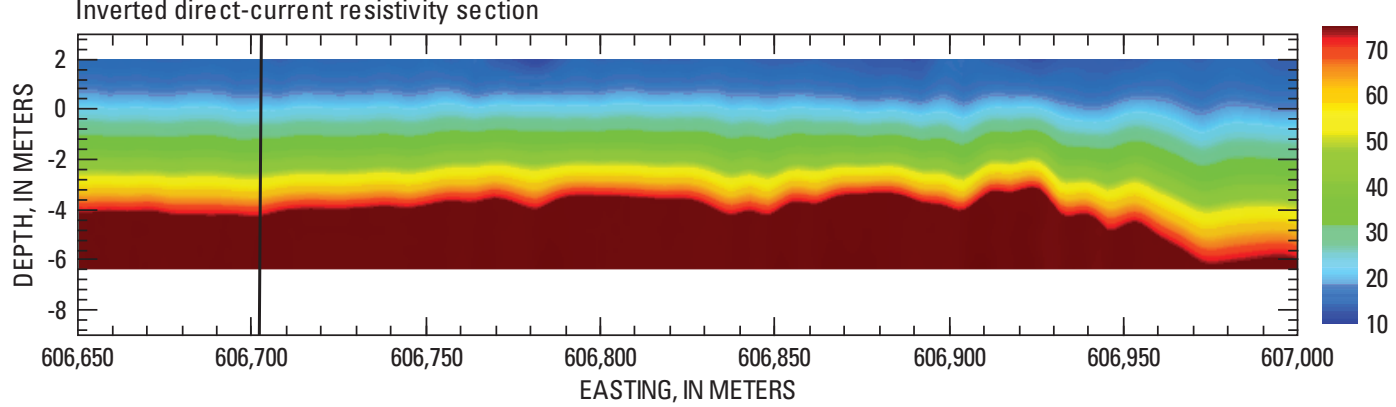

TH24

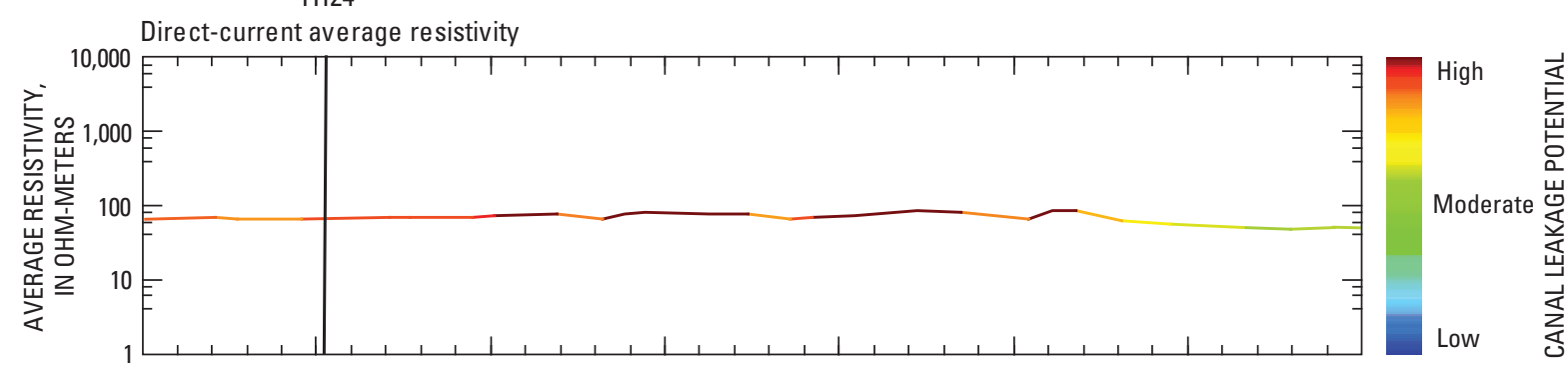

$-9-\therefore \therefore$

EASTING, IN METERS

EXPLANATION

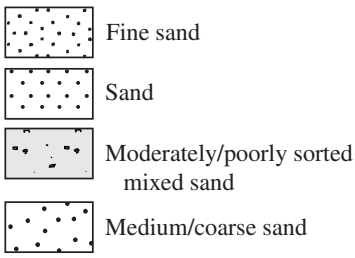

Figure 21. Comparison of $\boldsymbol{A}$, lithologic data from test hole 24 (TH24) drilled in the bed of the Tri-State Canal, to $\boldsymbol{B}$, inverted capacitively coupled and direct-current resistivity sections and average resistivity curves. 
$\boldsymbol{A}$

B
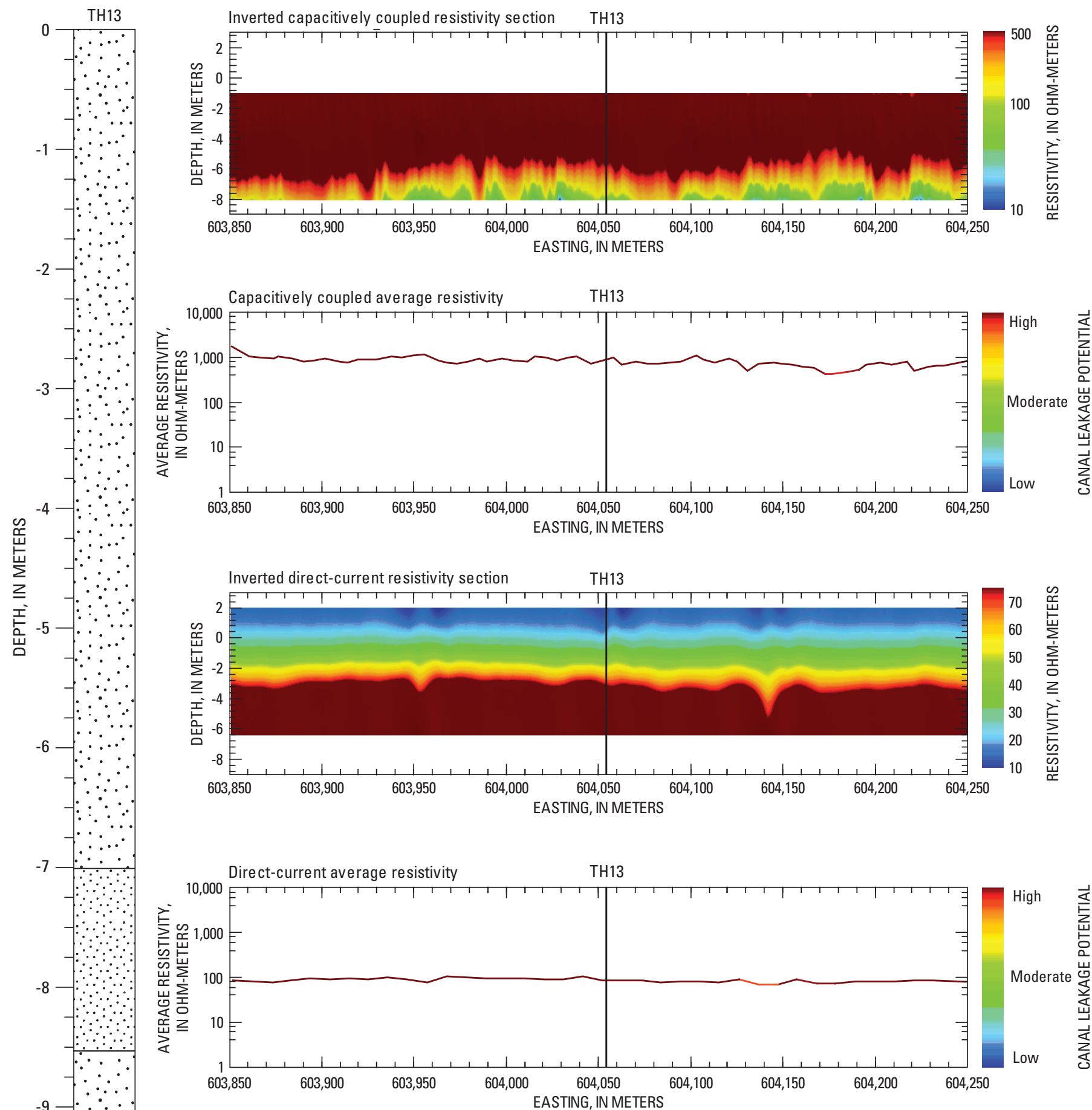

$\because \because$ Medium coarse $_{\text {sand }}$

$\because \because \because$ Fine sand

Figure 22. Comparison of $\boldsymbol{A}$, lithologic data from test hole 13 (TH13) drilled in the bed of the Tri-State Canal, to $\boldsymbol{B}$, inverted capacitively coupled and direct-current resistivity sections and average resistivity curves. 
$\boldsymbol{A}$

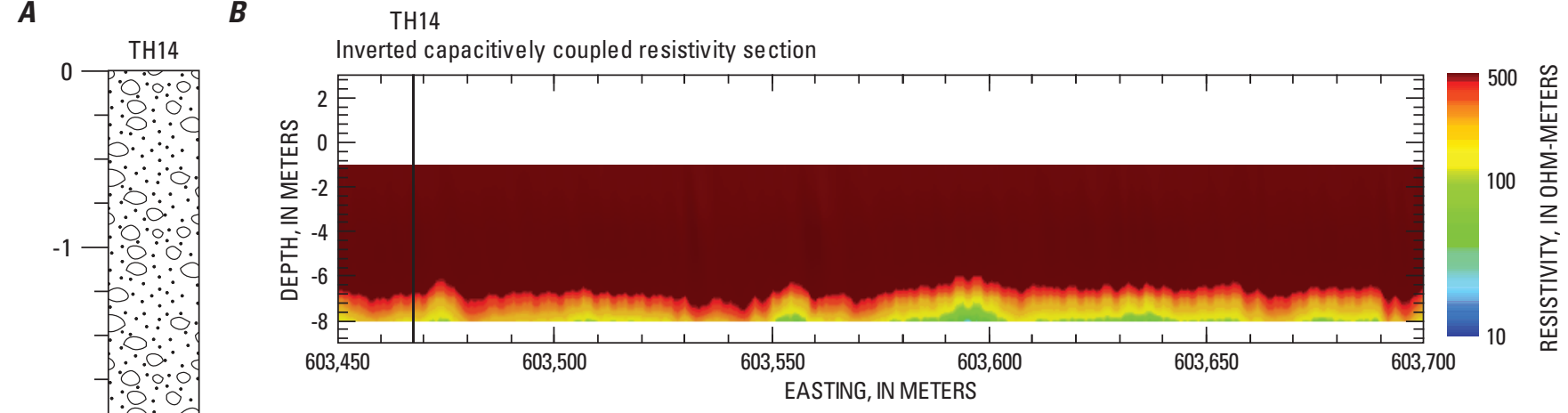

TH14

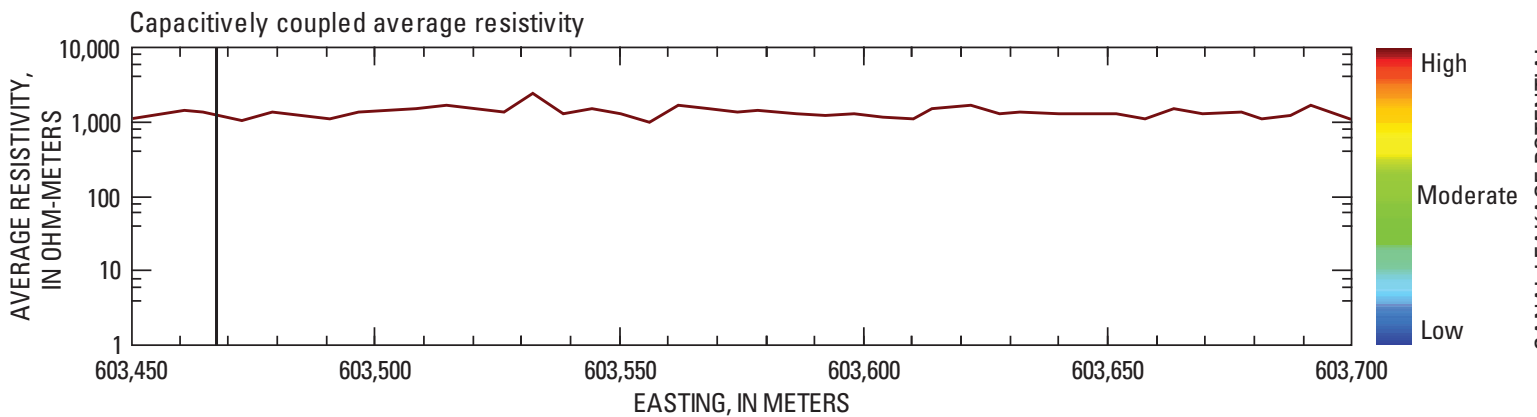

TH14

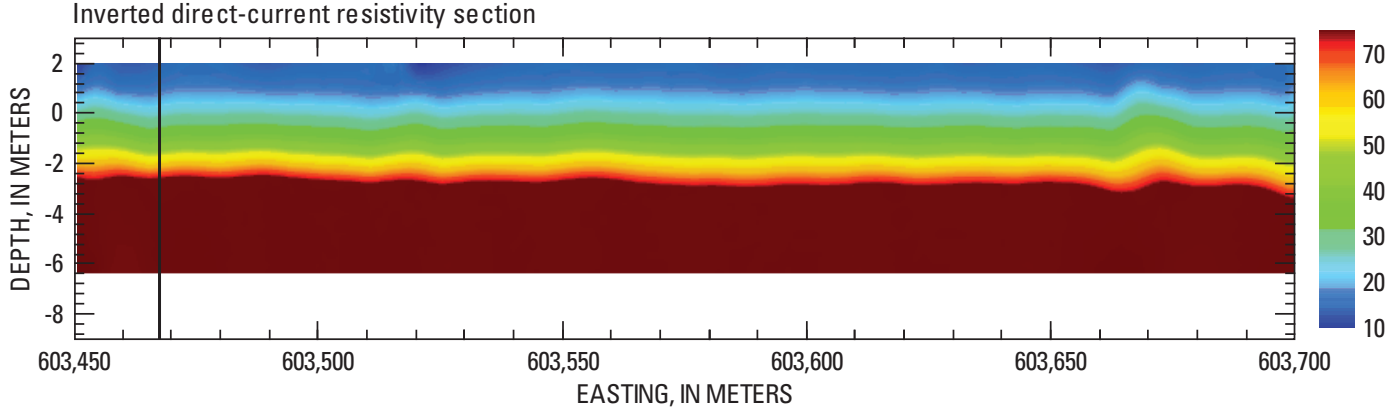

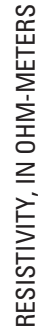

TH14

Direct-current average resistivity

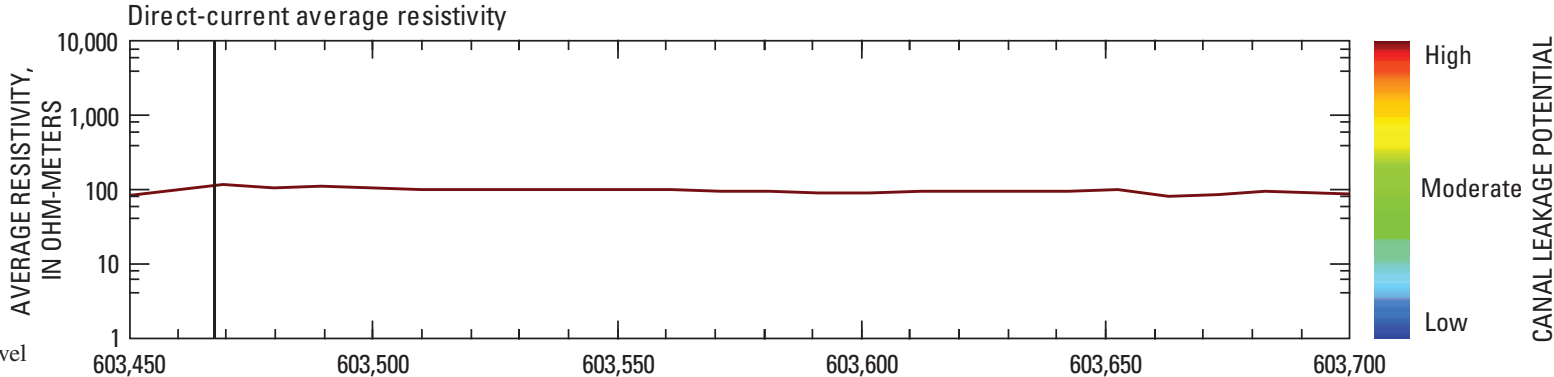

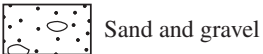

$\therefore$ Fine sand

EASTING, IN METERS

$\because \therefore$ Medium coarse

Figure 23. Comparison of $\boldsymbol{A}$, lithologic data from test hole 14 (TH14) drilled in the bed of the Tri-State Canal, to $\boldsymbol{B}$, inverted capacitively coupled and direct-current resistivity sections and average resistivity curves. 
A

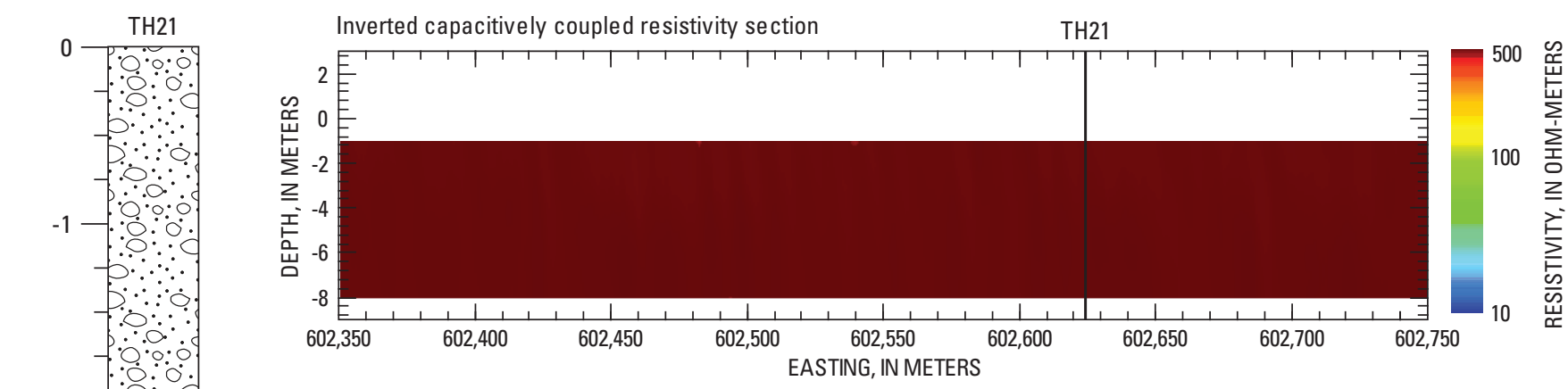

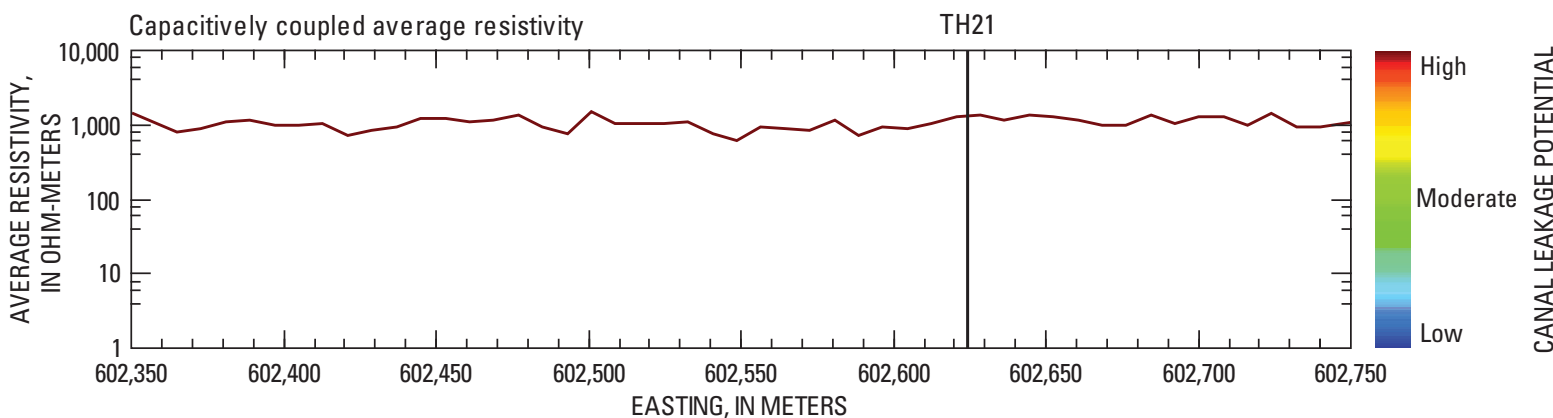
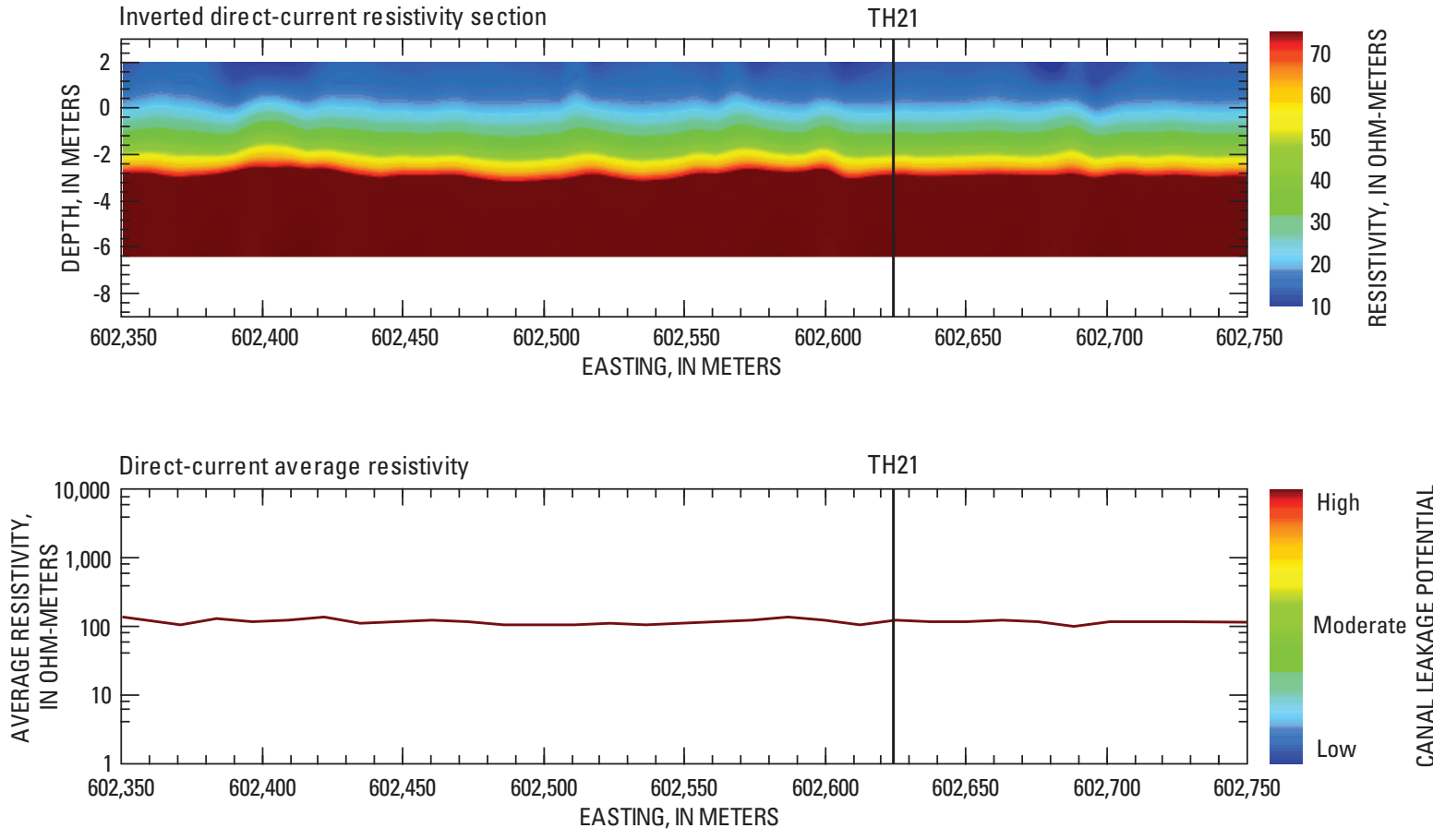

Figure 24. Comparison of $\boldsymbol{A}$, lithologic data from test hole 21 (TH21) drilled in the bed of the Tri-State Canal, to $\boldsymbol{B}$, inverted capacitively coupled and direct-current resistivity sections and average resistivity curves. 
$\boldsymbol{A}$

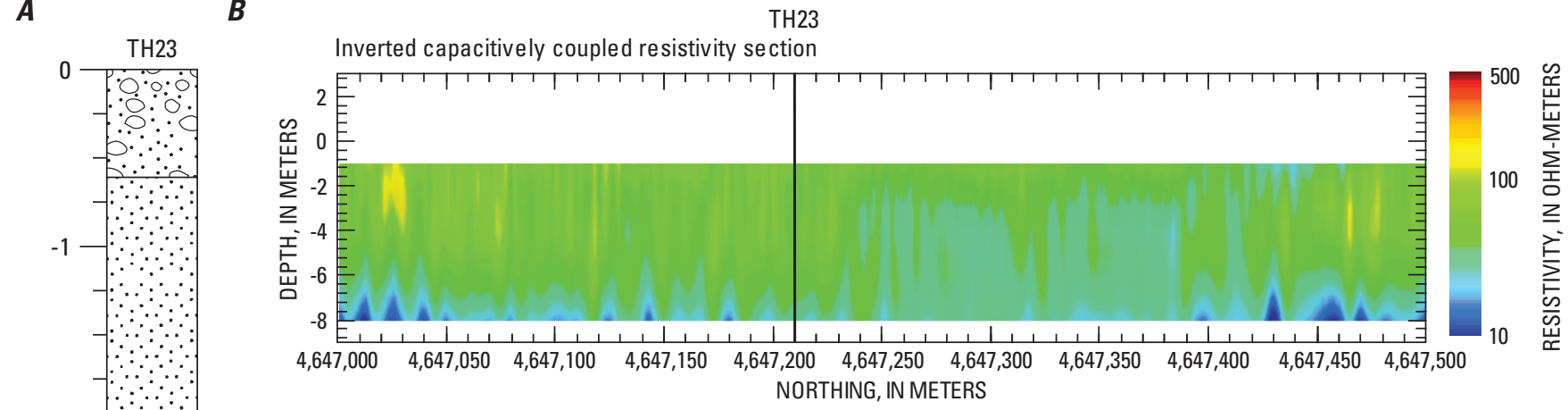

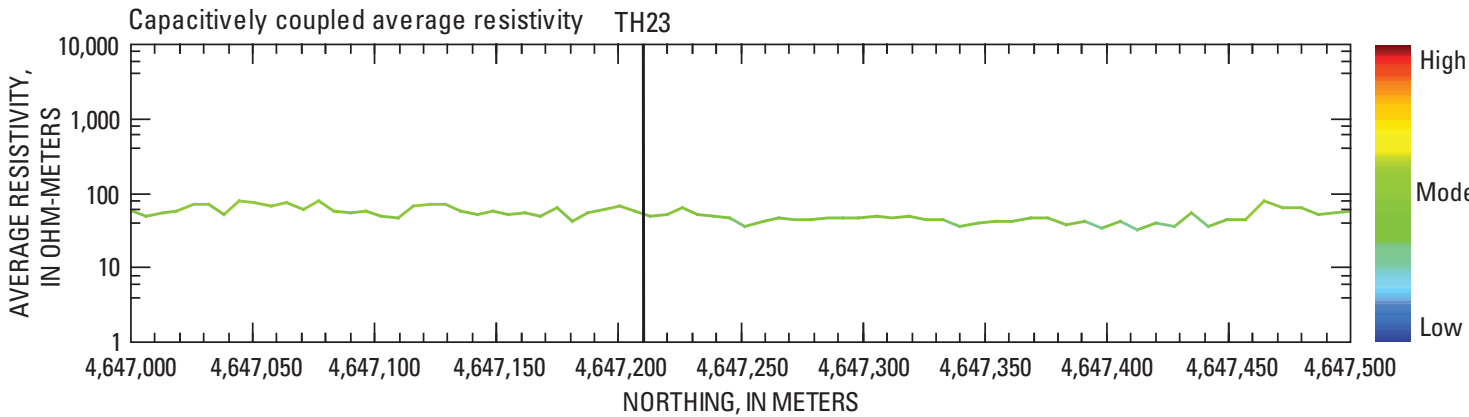
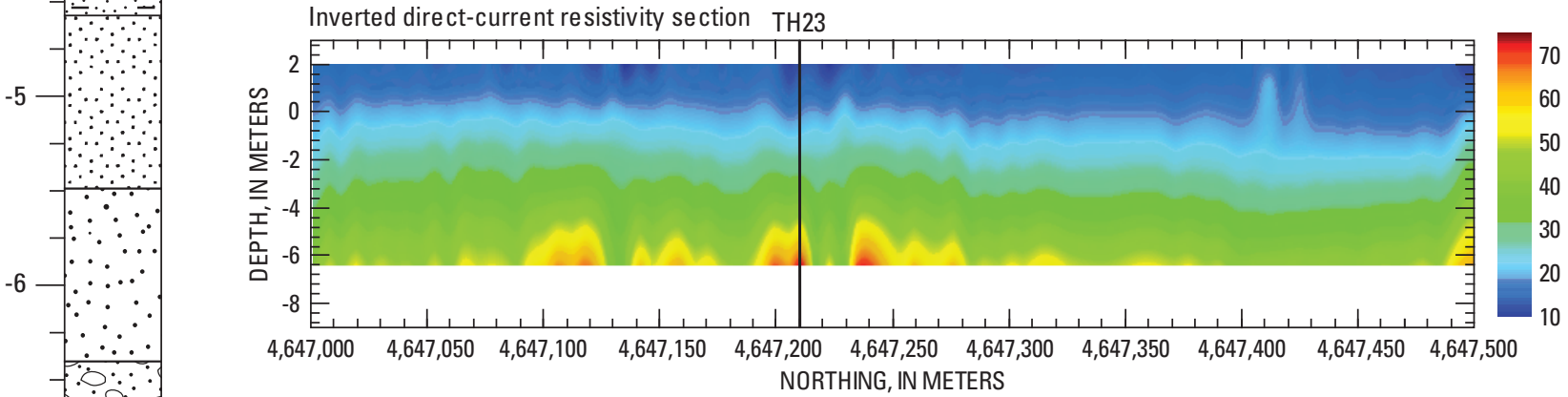
NORTHING, IN METERS

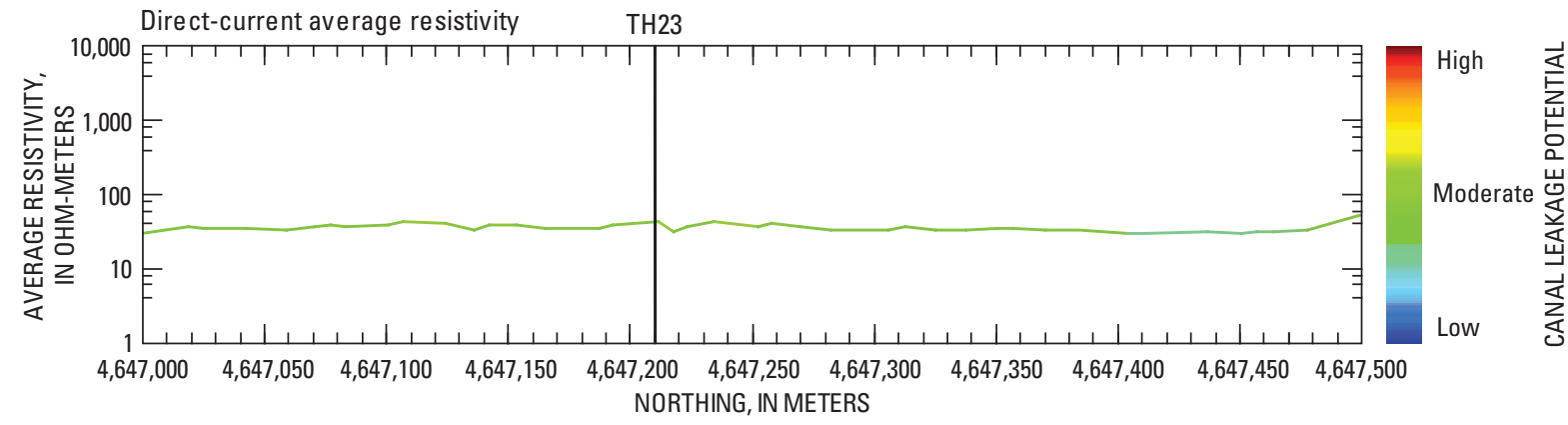

\section{EXPLANATION}

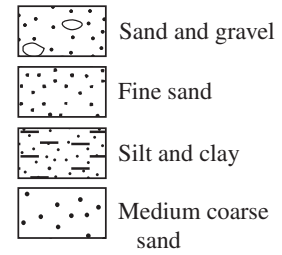

Figure 25. Comparison of $\boldsymbol{A}$, lithologic data from test hole 23 (TH23) drilled in the bed of the Tri-State Canal, to $\boldsymbol{B}$, inverted capacitively coupled and direct-current resistivity sections and average resistivity curves. 
$\boldsymbol{A}$

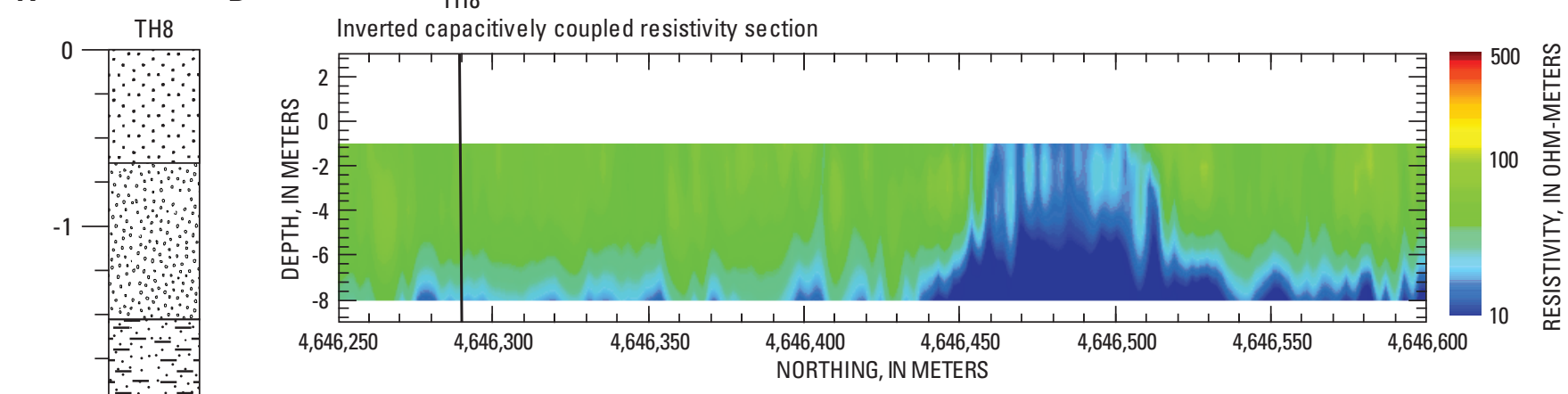

TH8

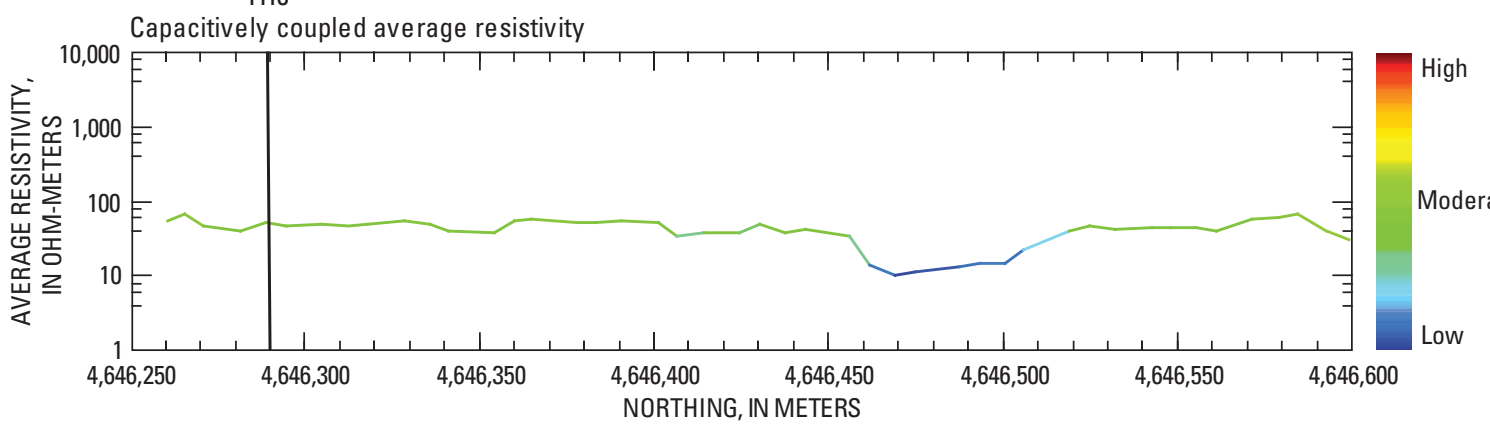

TH8

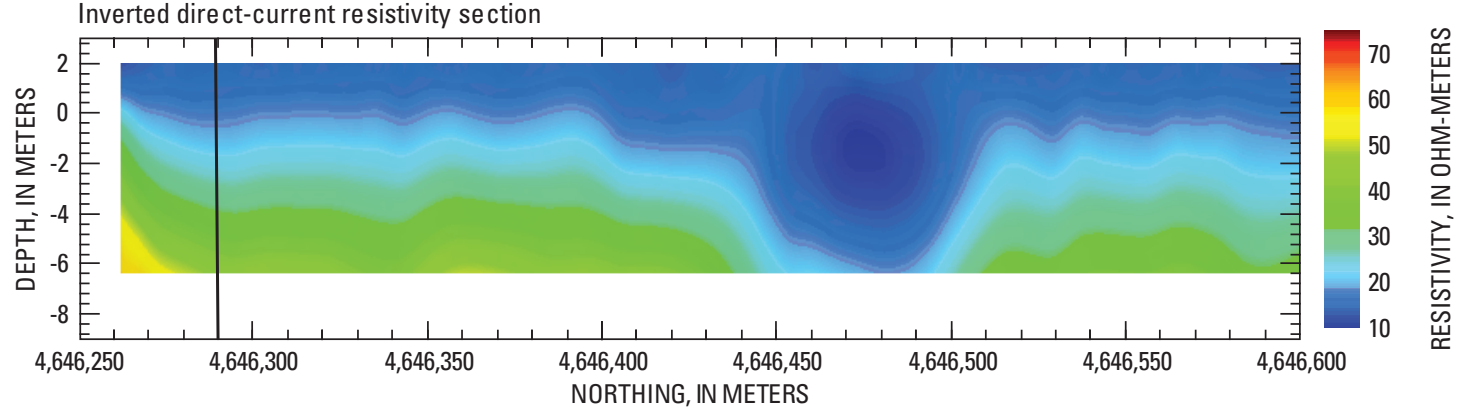

TH8

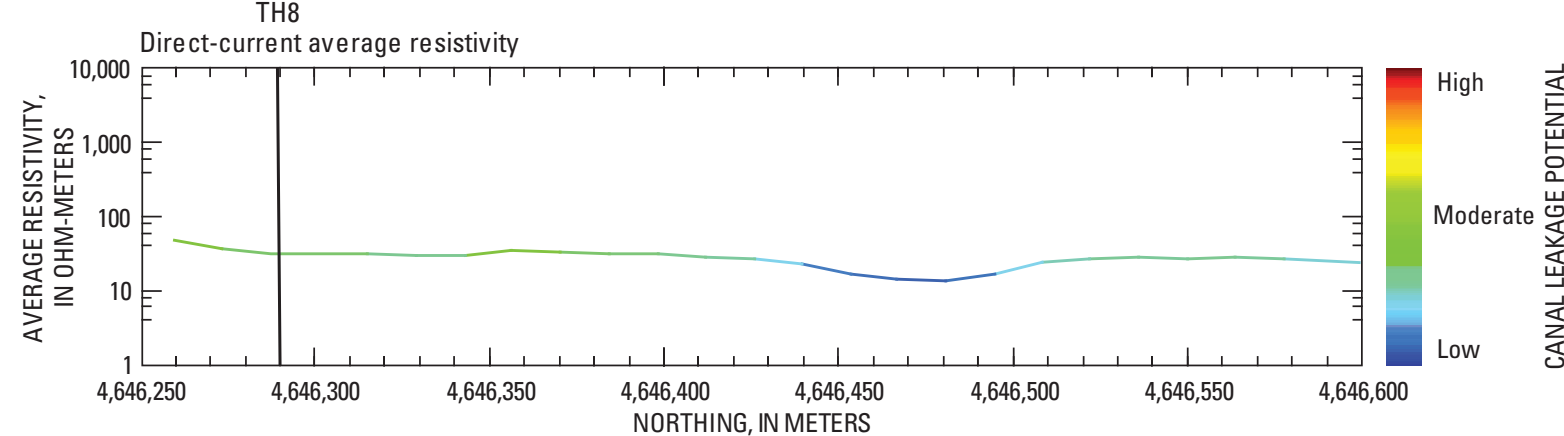

\section{EXPLANATION}

\begin{tabular}{|c|c|}
\hline & Fine sand \\
\hline & Very fine si \\
\hline & Silt and clay \\
\hline & $\begin{array}{l}\text { Medium/ } \\
\text { sand }\end{array}$ \\
\hline
\end{tabular}

Figure 26. Comparison of $\boldsymbol{A}$, lithologic data from test hole 8 (TH8) drilled in the bed of the Tri-State Canal, to $\boldsymbol{B}$, inverted capacitively coupled and direct-current resistivity sections and average resistivity curves. 
$\boldsymbol{A}$

\section{$B$}
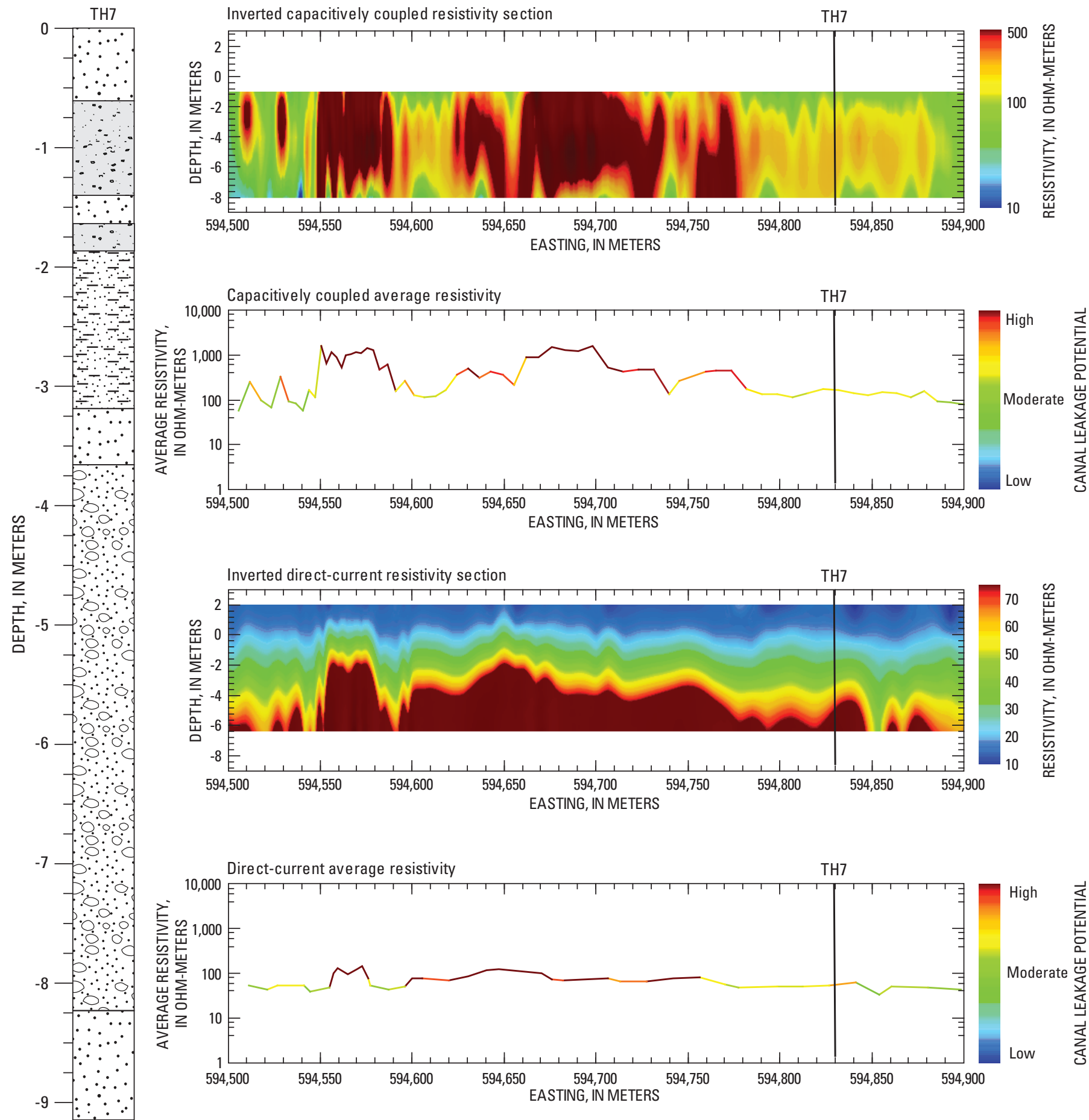

\section{EXPLANATION}

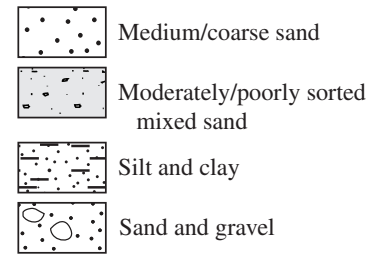

Figure 27. Comparison of $\boldsymbol{A}$, lithologic data from test hole 7 (TH7) drilled in the bed of the Tri-State Canal, to $\boldsymbol{B}$, inverted capacitively coupled and direct-current resistivity sections and average resistivity curves. 
For more information concerning the research in this report, contact:

Director, U.S. Geological Survey

Nebraska Water Science Center

5231 South 19th Street

Lincoln, Nebraska 68512

(402) 328-4100

http://ne.water.usgs.gov/ 

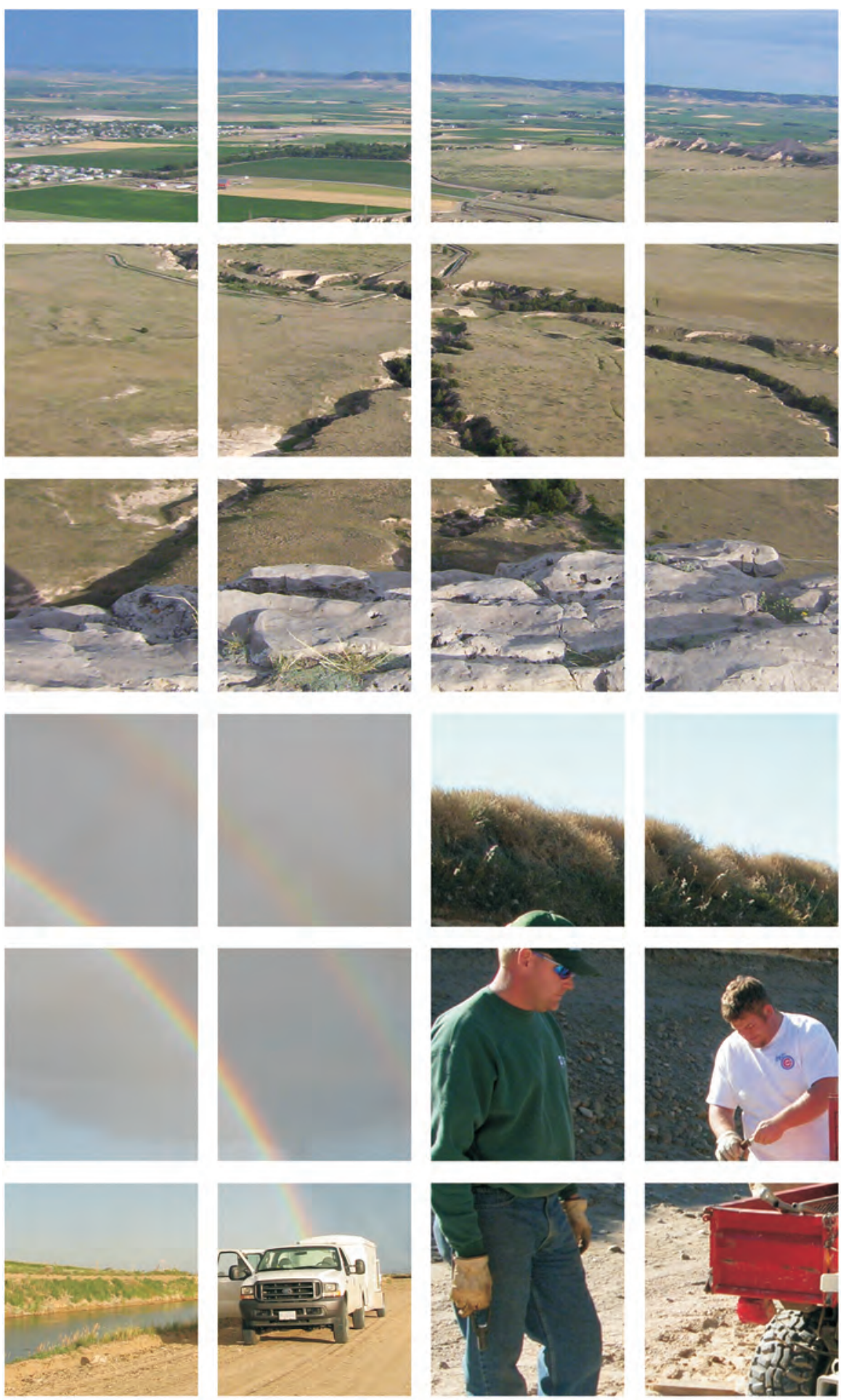

Printed on recycled paper
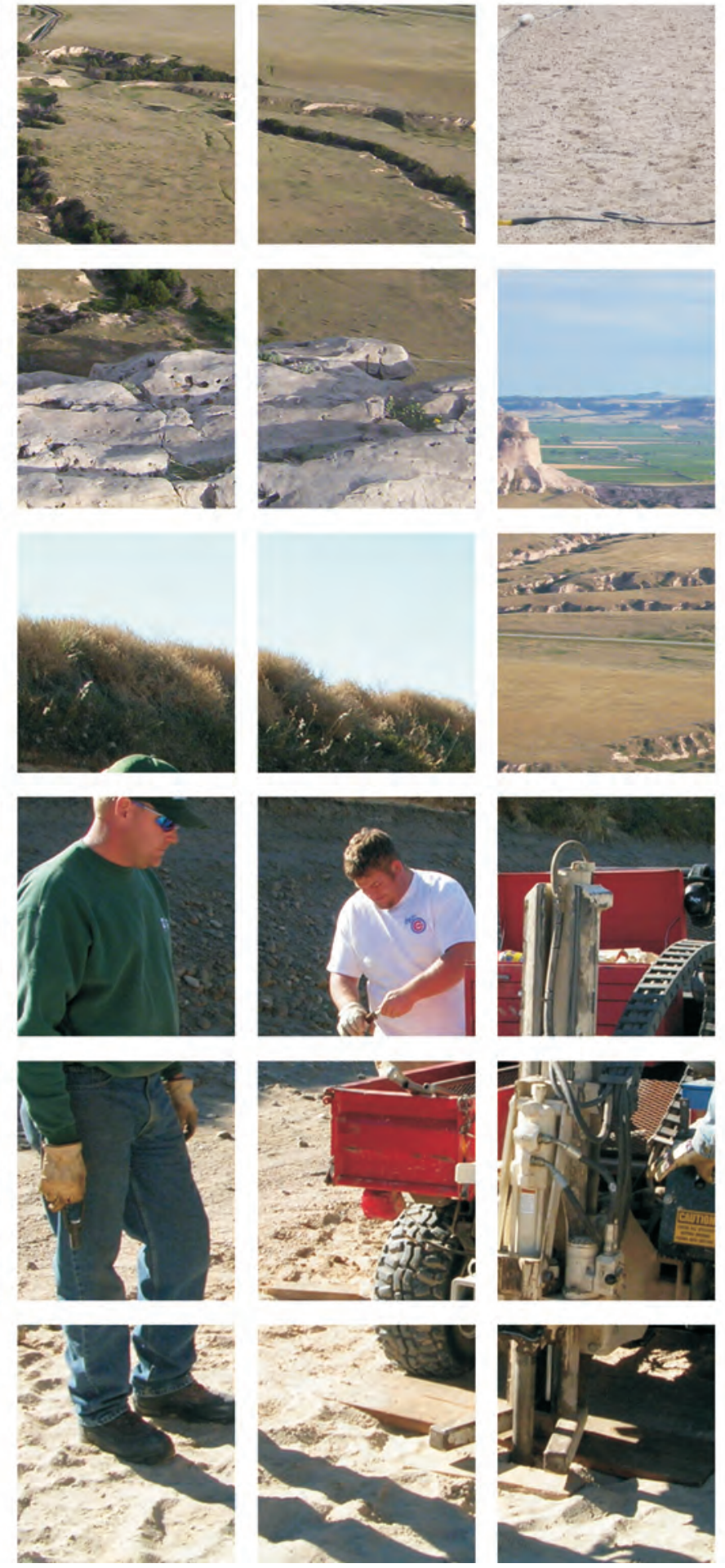
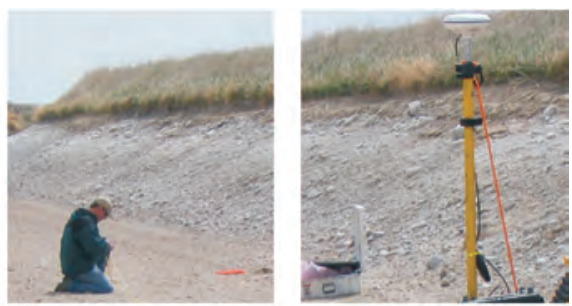

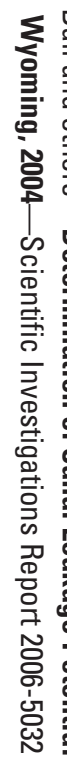
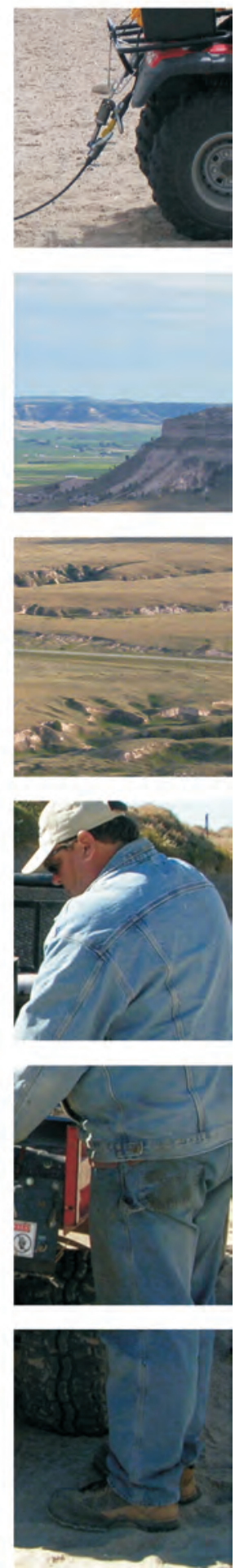